MARCIO HENRIQUE PEREIRA

CARACTERIZAÇÃO DO DESGASTE EM PUNÇÃO DE FORJAMENTO A QUENTE EM PRENSA HORIZONTAL AUTOMÁTICA DE MÚLTIPLOS ESTÁGIOS 
MARCIO HENRIQUE PEREIRA

\section{CARACTERIZAÇÃO DO DESGASTE EM PUNÇÃO DE FORJAMENTO A QUENTE EM PRENSA HORIZONTAL AUTOMÁTICA DE MÚLTIPLOS ESTÁGIOS}

Dissertação apresentada à Escola Politécnica da Universidade de São Paulo para obtenção do título de Mestre em Ciências.

Área de concentração: Engenharia Mecânica

Orientador: Prof. Dr. Roberto Martins de Souza

São Paulo 
Este exemplar foi revisado e corrigido em relação à versão original, sob responsabilidade única do autor e com a anuência de seu orientador.

São Paulo, de de

Assinatura do autor:

Assinatura do orientador:

Pereira, Marcio Henrique

CARACTERIZAÇÃO DO DESGASTE EM PUNÇÃO DE FORJAMENTO A QUENTE EM PRENSA HORIZONTAL AUTOMÁTICA DE MÚLTIPLOS ESTÁIOS / M. H. PEREIRA - versão corr. -- São Paulo, 2017. $110 \mathrm{p}$.

Dissertação (Mestrado) - Escola Politécnica da Universidade de São Paulo. Departamento de Engenharia Mecânica.

1.Forjamento a quente 2.Ferramentas (Desgaste) 3.Punção 4.Desgaste adesivo 5.Desgaste abrasivo I. Universidade de São Paulo. Escola Politécnica. Departamento de Engenharia Mecânica II.t. 
Aos que acreditaram em mim. 


\section{AGRADECIMENTOS}

A DEUS, agradeço por todo o meu conhecimento, a minha inteligência, a minha saúde e por sempre acompanhar-me, iluminando todos os meus caminhos.

Aos meus pais, Celso e Rosana, por todo o empenho e a dedicação em proporcionar o melhor para mim. Por estarem sempre ao meu lado, confortando e incentivando-me a vencer. Obrigado por ensinarem-me que, acima de tudo, existe um DEUS vivo no qual posso confiar a minha vida! Ao meu irmão Marcos, por ter me encaminhado à FEI, desbravando os caminhos da Engenharia e por ser o exemplo de que o Engenheiro, também é importante em outros segmentos da economia.

À minha irmã Milena, por ser um exemplo de dedicação e comprometimento. Por mostrar-me inúmeras vezes que sempre existe um outro ângulo de visão, mesmo quando se observa com os olhos pragmáticos de um Engenheiro. Obrigado por apontar o caminho para a USP.

À minha querida esposa, namorada, companheira e amiga Renata Madona, que surgiu na minha vida para mudá-la para sempre! Pelo apoio e pelo incentivo durante toda esta jornada deslumbrante. Obrigado por motivar-me com as suas palavras otimistas de um futuro melhor.

Ao meu orientador, professor e amigo, Roberto Martins de Souza. Por ter acreditado no potencial deste estudo e pelas inúmeras conversas de acompanhamento durante todo o Mestrado. Muito obrigado por orientar-me, ensinar-me e por, principalmente, ter tido paciência nesta longa jornada.

A todas as Professoras e a todos os Professores que dedicaram parte do tempo precioso, que muitas vezes é escasso, a ensinar-me com muita paciência. Sem eles, eu não poderia ter iniciado, nem mesmo, os agradecimentos deste trabalho.

À Neumayer Tekfor Automotive Brasil, por ter viabilizado e acreditado neste trabalho e, em especial, ao Diretor-Presidente Sr. Jorge Luiz Jacomini por acreditar nesta capacitação técnica.

Aos colegas de trabalho da Engenharia da Neumayer Tekfor, por incentivarem-me neste longo período de estudos. Em especial ao Gerente de Engenharia, Maurício Carlos Schledorn, pelo apoio e pelo incentivo ao estudo. A todo o time da forjaria da Neumayer Tekfor que sempre ensinou e auxiliou-me no desenvolvimento de novos produtos. Em especial, ao Miguel Munhoz, obrigado por ensinar os "truques" do forjamento.

Ao meu amigo Thales Sardinha Garcia Souza (Playboyzão), que juntos passamos boa parte do curso elucidando teorias e resolvendo problemas. Em especial, porque desde a FEI me acompanhou nos momentos de estudos, comemorações e em muitas corridas de kart. Valeu pela força Playboyzão.

Ao Dr.-Ing. Mauro Moraes de Souza, quem incentivou-me a buscar esta capacitação e por ser um grande exemplo de como o domínio de competências técnicas é importante nas tomadas de decisões do dia a dia. Por ensinar que, no fim das contas: "o ótimo é inimigo do bom".

Aos colaboradores do Laboratório de Fenômenos de Superfície da USP - LFS que me ensinaram, auxiliaram e orientaram. Em especial ao Rafael, por todas as imagens do MEV deste trabalho.

Aos colegas de sala da Poli que, durante alguns anos, dividiram opiniões, conhecimentos e inúmeras palavras de apoio, em especial ao Marcelo Octávio dos Santos.

À Escola Politécnica da USP. 
"Aquele que deseja mas não age, fomenta pestilência.” (William Blake) 


\section{RESUMO}

Concebido há milhares de anos, o forjamento passa por melhorias contínuas, mantendo-se como um processo de fabricação moderno, capaz de agregar características importantes a produtos forjados que são utilizados em inúmeras aplicações. $\mathrm{Na}$ indústria automobilística, responsável pelo consumo de cerca de $60 \%$ de todos os produtos forjados, o forjamento mostrou-se como um processo de conformação plástica eficaz no atendimento das especificações de resistência mecânica e nos quesitos de produtividade. Esta demanda por produtos forjados estimulou a busca por processos mais robustos, nos quais as ferramentas de forjamento possuem papel fundamental para possibilitar a produção de lotes maiores sem paradas de máquina devido a falhas. Cerca de $70 \%$ das falhas estão relacionadas ao desgaste das ferramentas. Este trabalho buscou identificar no ambiente industrial, os modos de desgaste responsáveis pela degradação da superfície de contato de um punção, fabricado em aço $\mathrm{H}-10$. Um conjunto de punções foi utilizado no forjamento a quente em prensa mecânica excêntrica horizontal e automática de múltiplos estágios, que utiliza água na refrigeração das ferramentas, durante a fabricação de porcas de roda, em aço SAE 1045. Os resultados obtidos basearam-se: (i) nas análises da superfície e da seção transversal de seis punções em microscópio eletrônico de varredura, (ii) na análise da nanodureza e (iii) na variação dimensional e da massa dos punções. Os resultados apontaram para o desgaste da superfície dos punções logo nas primeiras peças forjadas devido à transferência de óxidos do blank para a superfície da ferramenta. Nesta camada transferida para a superfície dos punções, foram encontrados danos causados pelo desgaste abrasivo e pela fadiga térmica.

Palavras-chave: Forjamento, ferramentas (Desgaste), punção, desgaste adesivo, desgaste abrasivo. 


\begin{abstract}
Since the initial development, thousands of years ago, forging has faced continuous improvements, remaining as a modern manufacturing process, capable of adding important characteristics to forged products that are used in numerous applications. In the automotive industry, responsible for the consumption of approximately $60 \%$ of all forged products, the forging has proved to be an effective metal forming process in terms of mechanical strength specifications and productivity requirements. This demand for forged parts has stimulated the search for more robust processes in which the forging tool has a fundamental role to enable the production of larger batches without downtime due to failures. Approximately $70 \%$ of these failures are related to tool wear. This work aimed identifying, in an industrial environmental, the wear modes responsible for the degradation of the contact surface of a punch, made of $\mathrm{H}-10$ steel. A series of punches was used for hot forging in a horizontal and automatic multi-stage eccentric mechanical press which uses water for tool cooling, during the manufacture of wheel nuts, made of SAE 1045 steel. Results were based: (i) on the analysis of the surface and cross section of six punches in a scanning electronic microscope, (ii) on nanohardness analyses and (iii) as well as on mass and dimensional variations. Results pointed to the punch wear in the first forged pieces, due to oxides transferring from blank to the punch surface. On this transferred layer to punch surface, have also found damage caused by abrasive wear and thermal fatigue.
\end{abstract}

Key words: Forging, tools (Wear), punch, adhesive wear, abrasive wear. 


\section{LISTA DE FIGURAS}

Figura 1 - Produção de veículos no Brasil de 1957 à 2016 (Adaptado de [1]).................................. 16

Figura 2 - Consumidores dos produtos forjados (Adaptado de [2]) .................................................. 17

Figura 3 - Produtos forjados utilizados na indústria automobilística [13] ...................................... 20

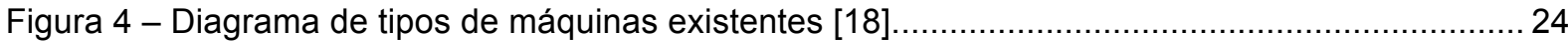

Figura 5 - Tribossistema genérico para qualquer par de superfícies em contato (Adaptado de [29]). 27

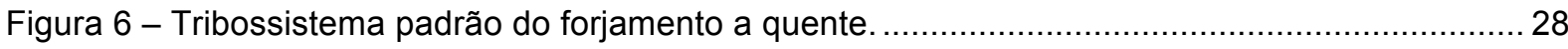

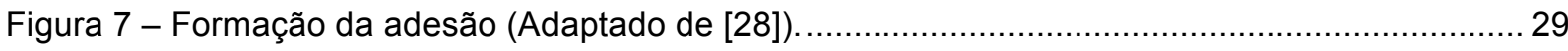

Figura 8 - Modelo de Archard para a formação de junções devido à adesão (Adaptado de [10]). ...... 30

Figura 9 - Morfologia lamelar das partículas aderidas soltas no tribossistema (Adaptado de [28]). ... 31

Figura 10 - Mecanismo de desgaste - Sulcamento por partículas aderidas (Adaptado de [28])....... 32

Figura 11 - Classificação da abrasão quanto à quantidade de corpos envolvidas no tribossistema (a)

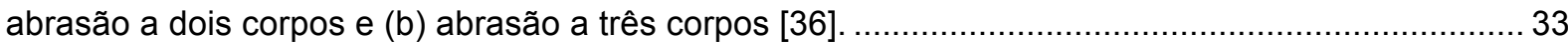

Figura 12 - Desgaste abrasivo em matriz de forjamento a quente com rebarba em prensa vertical. . 34

Figura 13 - Mecanismos de desgaste abrasivo por deslizamento da aspereza [39]......................... 35

Figura 14 - Mecanismo de desgaste abrasivo (Adaptado de [28]) ............................................... 36

Figura 15 - Trinca proveniente de fadiga mecânica em matriz de forjamento a quente de biela automotiva [12].

Figura 16 - Conceito esquemático da variação térmica. Em (a), expansão da microestrutura devido ao aquecimento. Em (b), contração devido ao resfriamento (Adaptado de [41]). 38

Figura 17 - Superfície da ferramenta afetada pela propagação de trincas térmicas em comparação com o leito de uma represa seca. (a) a superfície de uma matriz de forjamento de bielas automotivas com trincas térmicas [7]. (b), superfície de uma ferramenta de forjamento a quente com danos causados pela propagação de trincas provenientes da fadiga térmica [42]. (c), o leito da represa Jaguarí/Jacareí em Vargem/SP após um longo período de estiagem nos anos de 2014 e 2015 [43] 40 Figura 18 - Comparação da deformação plástica de um corpo de prova devido à máxima temperatura na superfície. (a) temperatura máxima $600^{\circ} \mathrm{C}$ e deformação máxima $0,14 \%$; (b) temperatura máxima $700^{\circ} \mathrm{C}$ e deformação máxima $0,18 \%$ (Adaptado de [42]).

Figura 19 - Refrigeração das ferramentas de forjamento a quente utilizadas na prensa mecânica horizontal de múltiplos estágios modelo Hatebur AMP70 (Adaptado de [8]). ..................................... 43

Figura 20 - Tribossistema típico do forjamento a quente (Adaptado de [6]) ........................................ 44

Figura 21 - Exemplos de diferentes superfícies desgastadas [19] ............................................. 48

Figura 22 - Variáveis que influenciam o desempenho das ferramentas (Adaptado de [47]).............. 49

Figura 23 - Desgaste em ferramentas de forjamento a quente (Adaptado de [55]). ......................... 50

Figura 24 - Modelo representativo da fórmula de Archard para determinar o volume de material

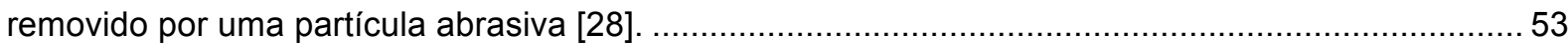

Figura 25 - Porca de roda para veículos pesados - caminhões e ônibus......................................... 55

Figura 26 - Porca forjada em aço SAE 1045. (a) Vista superior; (b) Perfil da porca com destaque para a transição do corpo sextavado para o corpo cilíndrico. 
Figura 27 - Sequência de forjamento da porca de roda: a) blank de aço SAE 1045 cisalhado; b)

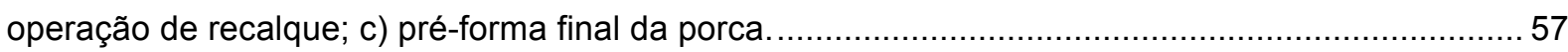

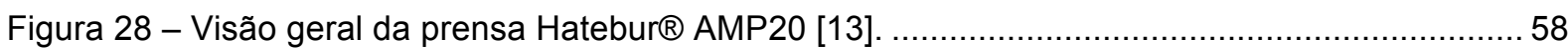

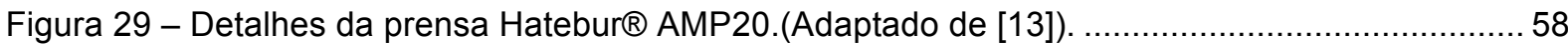

Figura 30 - Fluxograma de fabricação do punção de pré-furação..................................................... 59

Figura 31 - Punção PCP: (a) antes da medição; (b) desenho com cotas para serem dimensionadas.

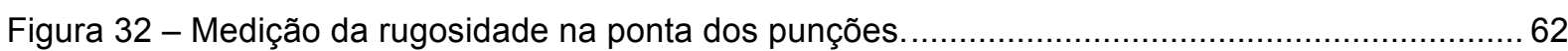

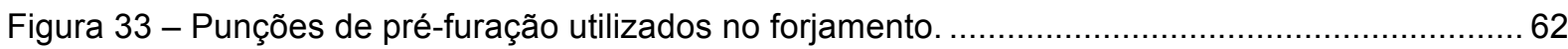

Figura 34 - Serra circular Struers Discotom automática do LFS utilizada no corte dos punções........ 64

Figura 35 - Corte dos punções: (a) corte da ponta do punção; (b) corte da seção longitudinal. .......... 65

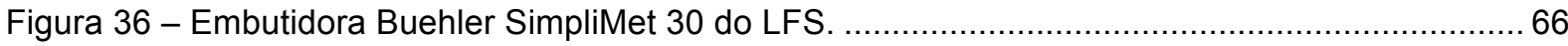

Figura 37 - Politriz automática Struers do LFS utilizada na preparação das amostras dos punções.. 68 Figura 38 - Amostra submetida ao ataque químico com nital 5\%. Em (a) amostras polida sem ataque

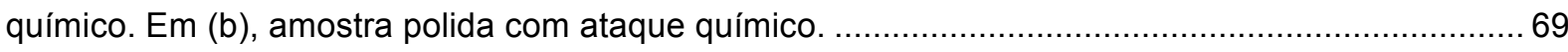

Figura 39 - Microscópio eletrônico de varredura - MEV JEOL JSM6010 instalado no LFS. .............. 70 Figura 40 - Triboindentador Hisytron TI950 do LFS: (a) Visão geral do equipamento. (b) Detalhe da área interna onde são feitas as impressões. (c) detalhe da mesa com as amostras posicionadas..... 71 Figura 41 - Diagrama do ciclo de impressão utilizado no Triboindentador Hisytron TI950 ................ 72

Figura 42 - Resultado da variação dimensional dos punções após o forjamento. ............................... 75

Figura 43 - Comparação da variação da massa dos punções. ……............................................. 76

Figura 44 - Punções utilizados nos forjamentos: (a) punções antes do forjamento; (b) os punções

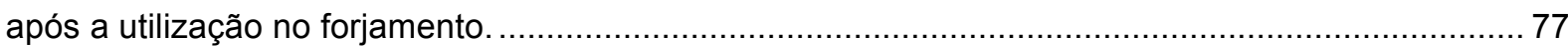

Figura 45 - Avaliação das superfícies dos punções após o forjamento: (a) P100; (b) P500; (c) P1000;

(d) P2000; (e) P10000.

Figura 46 - Análise das superfícies dos punções, detector BSE com aumento 50x: (a) Punção PCP;

(b) Punção P100; (c) Punção P500; (d) Punção P1000; (e) Punção P2000; (f) Punção P10000 ........ 82

Figura 47 - Análise da topografia da lateral dos punções. Detector SE com aumento 50x: (a) PCP; (b)

P100; (c) P500; (d) P1000; (e) P2000; (f) P10000

Figura 48 - Análise da topografia da lateral dos punções. Detector BSE com aumento 500x. (a) PCP;

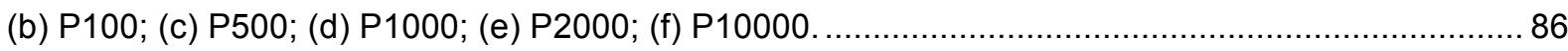

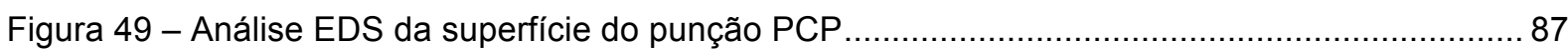

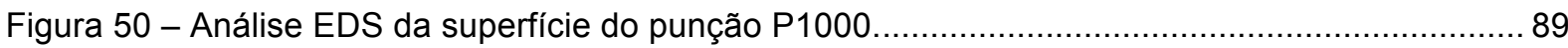

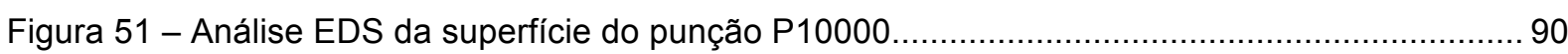

Figura 52 - Análise MEV da seção transversal dos punções utilizando detector para BSE com aumento de 500x. (a) PCP; (b) P100; (c) P500; (d) P1000; (e) P2000; (f) P10000......................... 93

Figura 53 - Comportamento adesivo na superfície dos punções.

Figura 54 - EDS da seção transversal do punção P500 - Mapa de concentração de elementos químicos. (a) região analisada com detector BSE; (b) Fe; (c) O; (d) V; (e) Mo; (f) Cr........................ 97

Figura 55 - Formação dos óxidos no blank durante o forjamento. 
Figura 56 - Análise da seção transversal do blank recalcado - interface de contato com a ferramenta.

Figura 57 - Análise da seção transversal do blank recalcado - lateral.......................................... 100

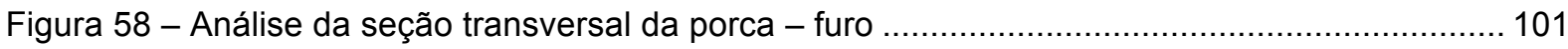

Figura 59 - Análise da seção transversal da porca forjada - Raio do furo ....................................... 102

Figura 60 - Mapa de impressões realizadas na camada aderida do punção P2000 ......................... 103

Figura 61 - Resultado da nanodureza da camada sobre a superfície dos punções.......................... 104 


\section{LISTA DE TABELAS}

Tabela 1 - Comparativo das capacidades e limitações dos tipos de forjamento (Adaptado de [18]) . 22

Tabela 2 - Composição química dos aços-ferramentas com base em cromo - AISI [5] .................... 25

Tabela 3 - Composição química dos aços-ferramentas com base em tungstênio - AISI [5] ............. 25

Tabela 4 - Composição química dos aços-ferramenta baixa liga - AISI [5] ..................................... 25

Tabela 5 - Temperaturas típicas de forjamento de materiais metálicos (Adaptado de [10]) . .............42

Tabela 6 - Durezas dos óxidos de ferro medidos à temperatura ambiente (Adaptado de [49,51,52]). 45

Tabela 7 - Quantidade de oxidação aceitável conforme o forno utilizado para aquecer o blank [10] . 45

Tabela 8 - Classificação do desgaste: (a) moderado; (b) severo (Adaptado de [10]) ........................51

Tabela 9 - Coeficientes de desgaste "K" obtidos em ensaios pino disco (Adaptado de [40])............. 52

Tabela 10 - Composição química do aço SAE1045 utilizado no forjamento [58]................................. 56

Tabela 11 - Composição química do aço da $\mathrm{H}-10$ utilizado nos punções [20]. ................................... 59

Tabela 12 - Comparação da rugosidade nos punções usados em comparação com o punção PCP. 80

Tabela 13 - Composição química da superfície do punção PCP obtida por EDS ……........................ 88

Tabela 14 - Composição química da superfície do punção P1000 obtida por EDS …........................ 89

Tabela 15 - Composição química da superfície do punção P10000 obtida por EDS. .......................... 91 


\section{SUMÁRIO}

1. INTRODUÇÃO

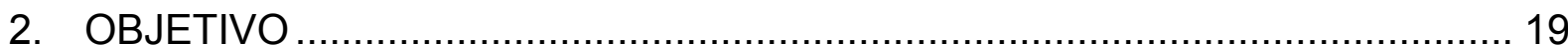

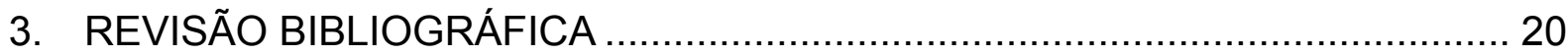

3.1. Forjamento

3.1.1. Equipamentos de forjamento ....................................................... 23

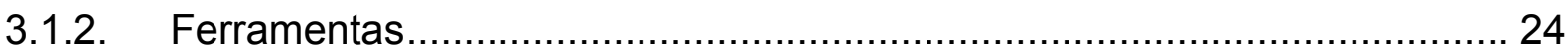

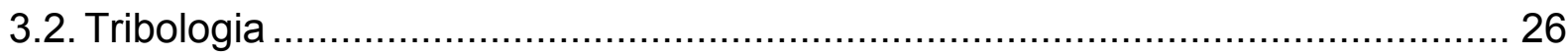

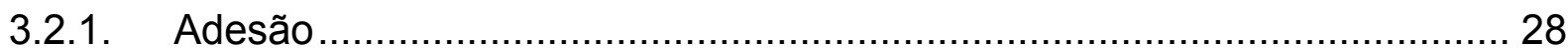

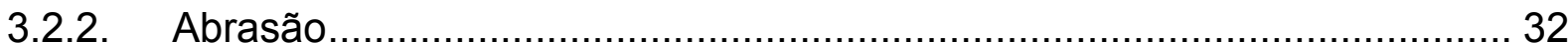

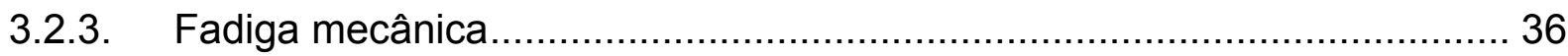

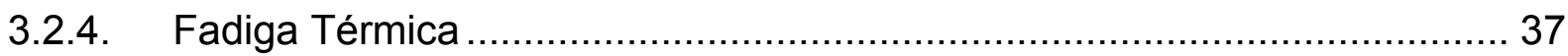

3.2.5. Tribologia no Forjamento a Quente ....................................................... 43

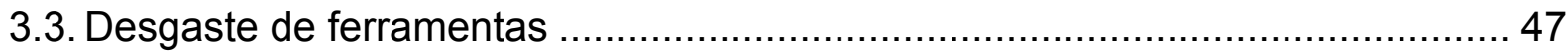

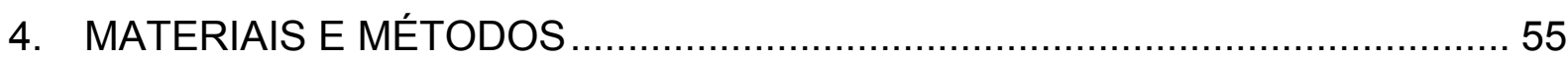

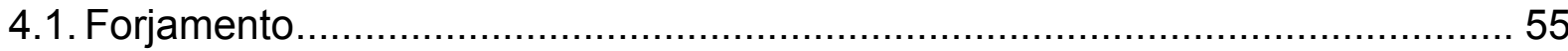

4.2. Ferramenta - Punção de Pré-furação ............................................................... 59

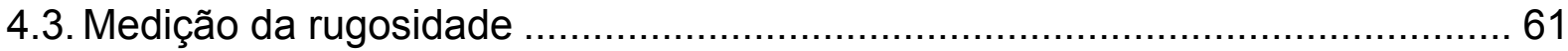

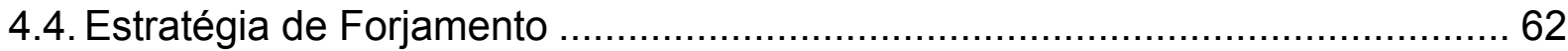

4.5. Preparação das Amostras para Análises ........................................................ 63

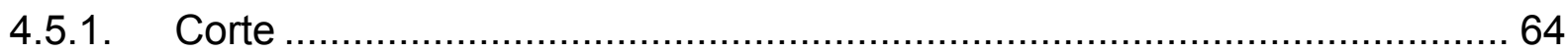

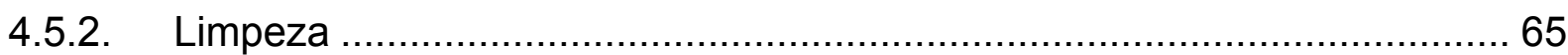

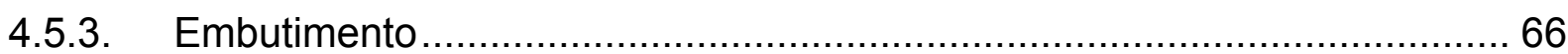

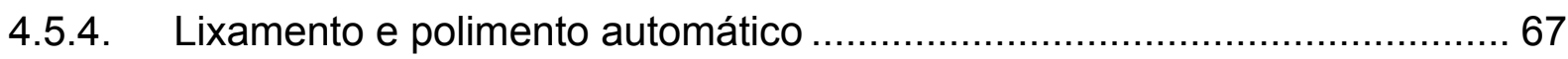

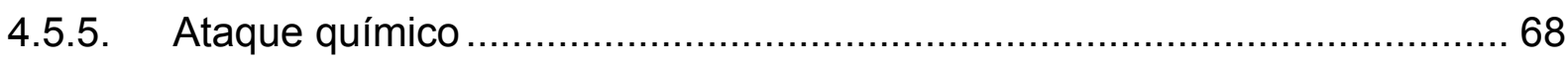

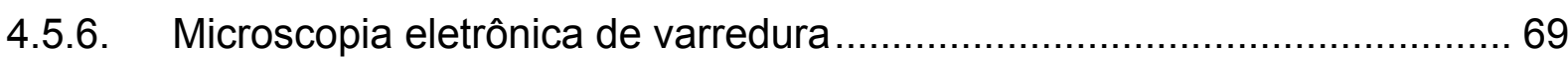




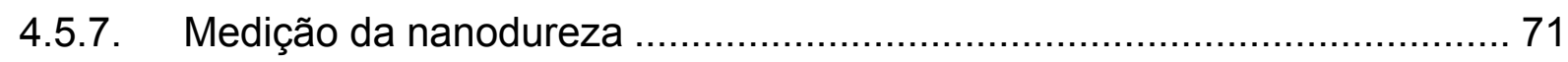

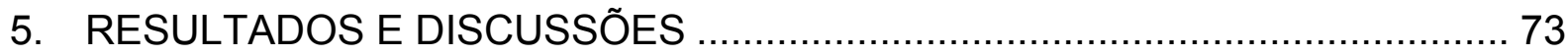

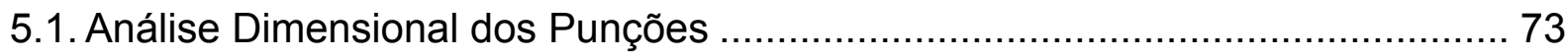

5.2. Aspecto das Superfícies dos Punções ................................................. 76

5.3. Análise da Superfície do Punção......................................................... 79

5.4. Análise da Seção Transversal dos Punções ........................................... 91

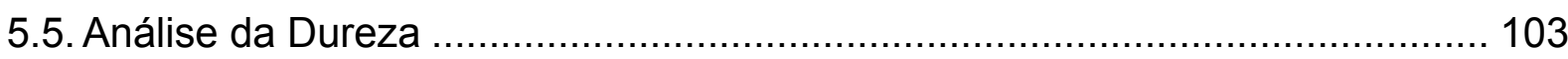

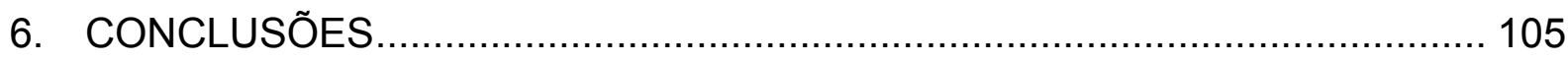

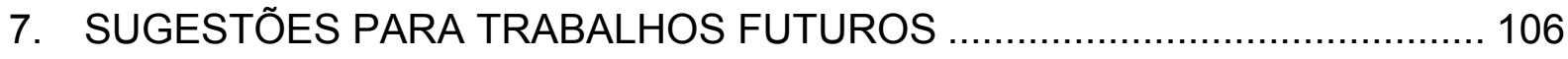

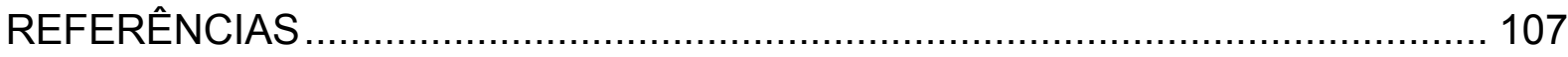




\section{INTRODUÇÃO}

A indústria automobilística se desenvolve desde o início do século $X X$, quando Henry Ford expandiu os conceitos de produção em linha, buscando a redução dos custos produtivos e o aumento da produtividade. Crescendo com taxas elevadas, países como Estados Unidos, China e Japão são responsáveis por grande parte da demanda de automóveis. Junto com Alemanha, Coreia do Sul, Índia, México e Brasil, estes países produziram mais de 95 milhões de veículos em 2016. No Brasil, ao longo de 59 anos, a indústria automobilística cresceu e atingiu o recorde de produção no ano de 2013, quando produziu o total de 3.712 .736 veículos, conforme a Figura 1, onde estão as quantidades de veículos produzidos e comercializados de 1957 a 2016. Do total de veículos produzidos em 2013, 25\% são caminhões, ônibus e veículos fora de estrada [1].

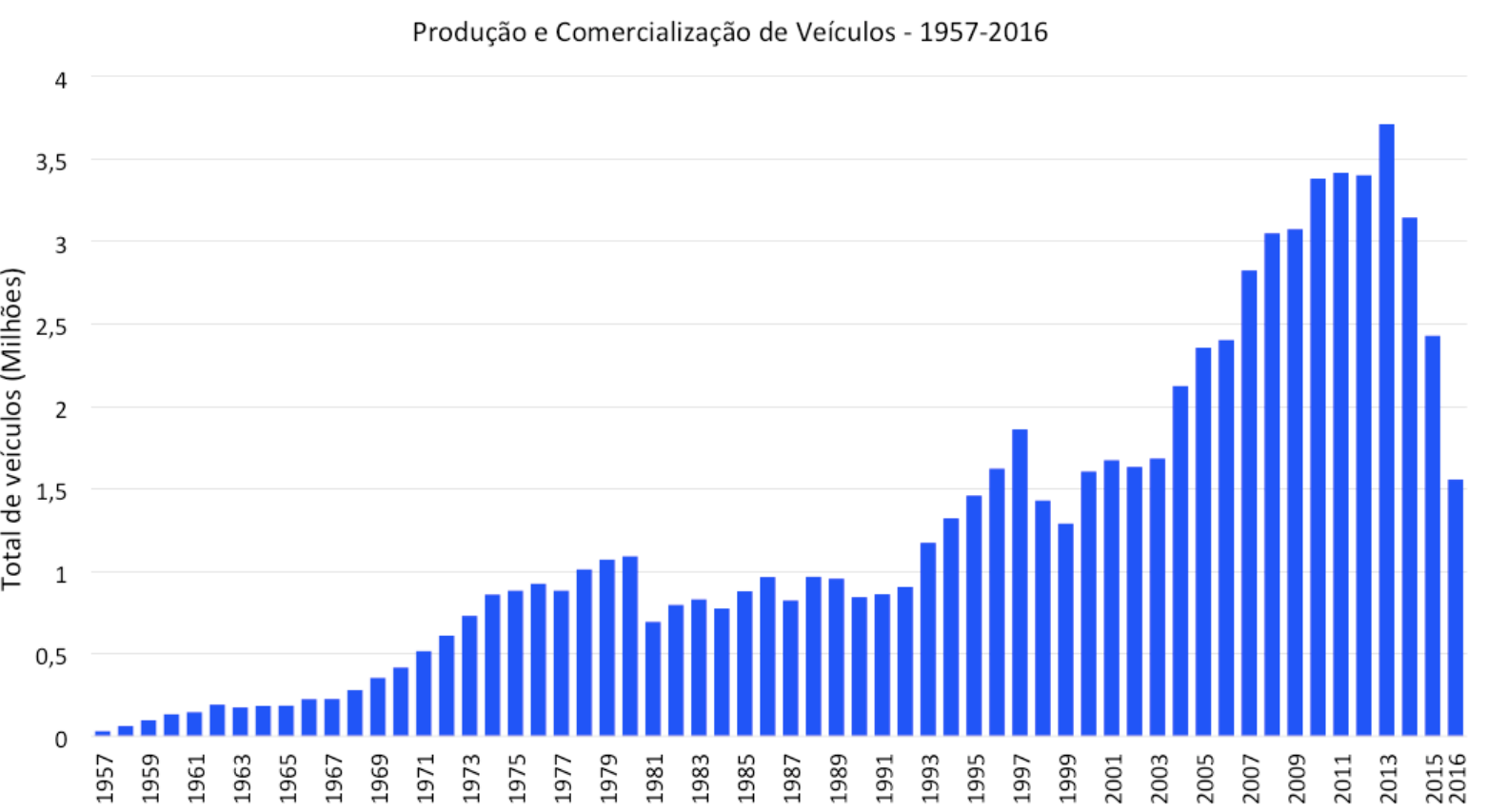

Figura 1 - Produção de veículos no Brasil de 1957 à 2016 (Adaptado de [1]).

Junto com a expansão da indústria automobilística, diversos processos de fabricação foram criados e aperfeiçoados, um exemplo disto é a conformação plástica de metais. Dentre os tipos de conformação plástica, forjamento é um dos principais processos de fabricação responsáveis por abastecer a indústria 
automobilística com produtos metálicos, segundo dados da EUROFORGE ${ }^{1}$ [2]. ALTAN [3], apresentou números da indústria de forjamento com destaque para a maciça participação da indústria automobilística. Estudos recentes da EUROFORGE [2] validam a observação feita por ALTAN [3] e mostram que atualmente $58 \%$ da produção de forjados é destinada à indústria automobilística. A Figura 2 mostra que além da indústria automobilística, outros setores utilizam produtos forjados nas suas respectivas aplicações [2].

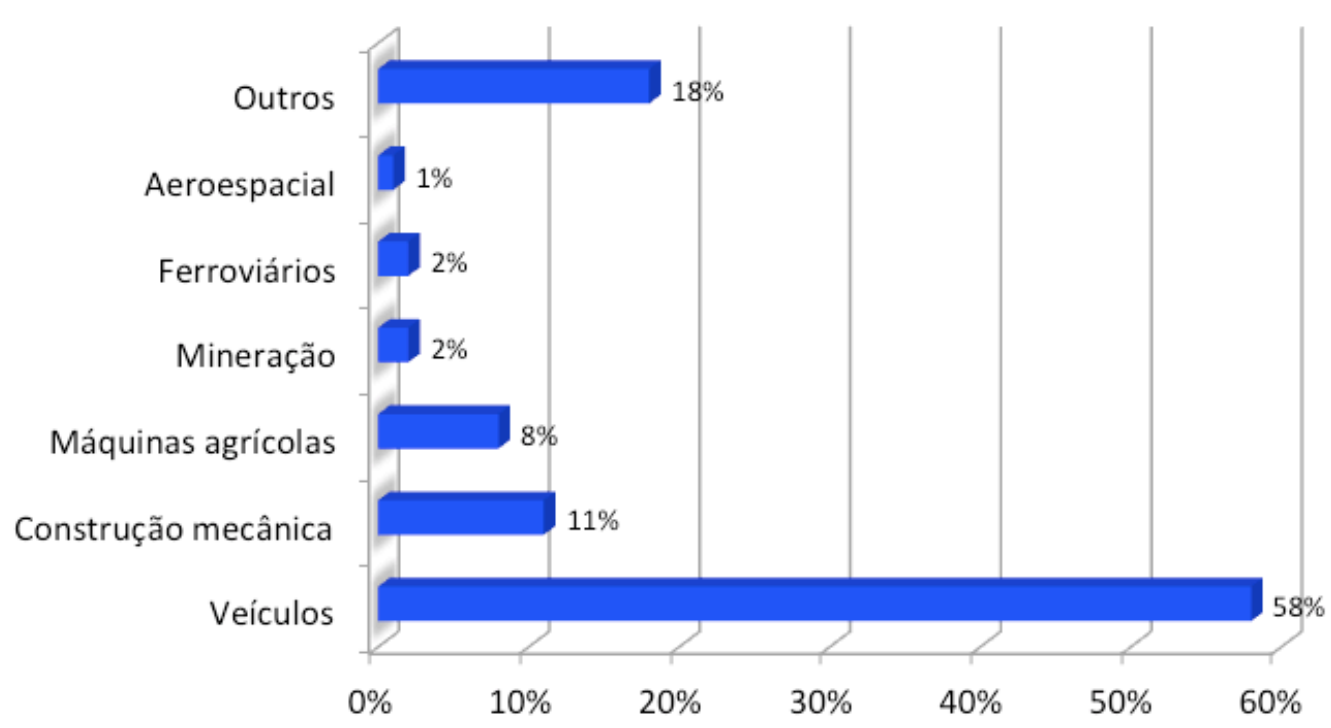

Figura 2 - Consumidores dos produtos forjados (Adaptado de [2]).

Em 2014, a produção mundial de forjados foi superior a 25,7 milhões de toneladas. No Brasil, foram forjadas 514 mil toneladas de produtos, o que corresponde a $2 \%$ da produção mundial de forjados [4]. Na indústria metalúrgica, os processos de conformação fazem parte da fabricação da maioria dos produtos utilizados nas linhas de produção. Esses produtos podem ser obtidos exclusivamente por conformação plástica ou a utilizam como parte do processo produtivo para a obtenção de um blank ${ }^{2}$, que posteriormente sofrerá outra transformação $[5,6]$. Para atender a demanda crescente por produtos forjados,

\footnotetext{
${ }^{1}$ Euroforge é uma associação de fabricantes de produtos forjados da Europa.

${ }^{2}$ Blank é termo em inglês comumente utilizado para descrever o material que será forjado. A tradução mais aceita em português para blank é tarugo. Existem autores que utilizam o termo, também em inglês, billet. No entanto, com menos frequência.
} 
inúmeros desenvolvimentos foram feitos em materiais, máquinas, ferramentas e nos processos [2-6].

As melhorias feitas destacaram ainda mais uma das grandes vantagens do forjamento; a possibilidade de produzir uma grande quantidade de peças em um curto espaço de tempo [4-8]. Porém, para a produção de peças forjadas que atendam as especificações de projeto são necessárias ferramentas que suportem os esforços mecânicos, o desgaste e a fadiga durante toda a sua utilização na produção. Além de serem responsáveis pela qualidade dimensional e superficial dos produtos forjados, o uso das ferramentas deve ser potencializado para aumentar a produtividade e reduzir os tempos de parada de máquina para substituição [4-7]. Por isso, é natural supor que quanto mais longa for a utilização dessas ferramentas menor será o custo do produto forjado. SUMMERVILLE et al. [9] apontavam que o custo das ferramentas era de cerca de $10 \%$ do custo total do produto forjado. Segundo MAGRI, o custo das ferramentas de forjamento pode chegar a até $30 \%$ do custo do produto forjado [7]. No entanto, estimativas recentes apontam para o custo de ferramentas entre $15 \%$ e $23 \%$ no custo final do produto para o forjamento em prensas horizontais de múltiplos estágios [4]. O custo das ferramentas já considera a parcela devido ao desgaste das ferramentas, sendo que o seu impacto se estende a aos custos de parada de máquina para substituição de ferramentas, perda de produtividade e perda de produção [10]. O desgaste destaca-se como um dos principais responsáveis pelos danos causados às ferramentas de forjamento [7,1112]. Um conjunto complexo de variáveis torna o seu estudo um grande desafio e uma fonte de melhorias para o aumento do desempenho quando utilizadas no forjamento a quente $[4-6,13]$.

Este trabalho focou exclusivamente no desgaste de uma ferramenta utilizada na fabricação de elemento de fixação para aplicação automotiva. Para estudar o comportamento ao desgaste desta ferramenta, o trabalho analisou o forjamento a quente em uma prensa mecânica excêntrica horizontal de múltiplos estágios utilizada em ambiente industrial. 


\section{OBJETIVO}

O foco principal deste trabalho é caracterizar o desgaste do punção de forjamento a quente utilizado em prensa mecânica horizontal automática de múltiplos estágios para fabricar elementos de fixação para a indústria automobilística. 


\section{REVISÃO BIBLIOGRÁFICA}

A base para a fabricação de muitos produtos destinados à indústria automobilística é a conformação plástica dos metais. A possibilidade de produzir um número elevado de produtos em pouco tempo e com repetibilidade faz deste processo um aliado importante da produção com custos baixos $[3,5,6]$.

Entre os processos de conformação existentes na indústria automobilística, destacam-se a estampagem e forjamento $[3,5,6,13]$.

\subsection{Forjamento}

O forjamento desenvolveu-se ao longo de milhares de anos e faz parte de uma série de processos de transformação que utilizam a conformação plástica de metais [5,14]. A conformação plástica é um dos principais processos de fabricação existentes nas indústrias e é parte da maioria dos processos de fabricação de produtos em aço $[3,5,6,13,14]$. A Figura 3 apresenta diversos produtos obtidos pelos processos de forjamento e que são utilizados na indústria automobilística.

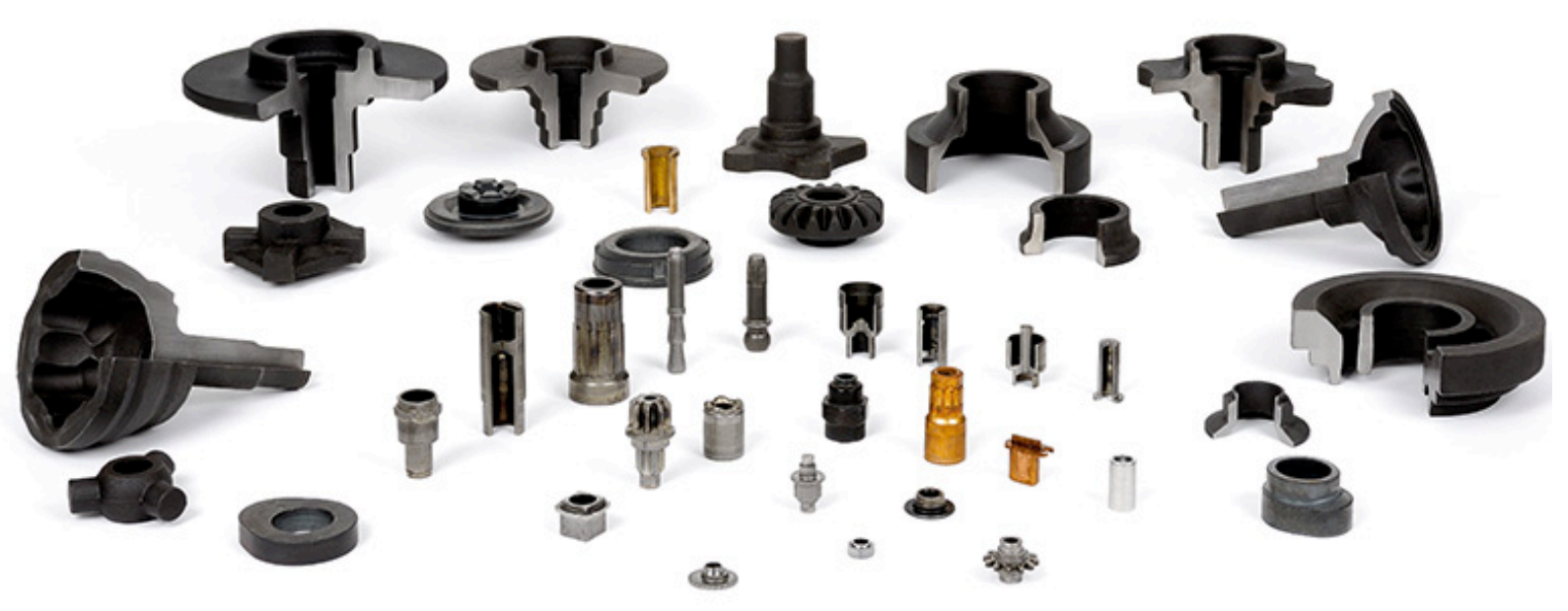

Figura 3 - Produtos forjados utilizados na indústria automobilística [13].

Desde os primeiros registros de produtos conformados, em 8000 A.C. até hoje, grandes avanços marcaram a evolução do forjamento [3-6,8]. Os avanços se 
deram em tipos de materiais utilizados no forjamento, no controle das variáveis de processo e na aplicação de técnicas avançadas de projeto de ferramentas. Estas iniciativas foram responsáveis pelo menor consumo de matéria-prima, menor consumo de energia elétrica, maior produção e menor quebra de ferramentas, consequentemente produzindo produtos de elevada qualidade a custos moderados $[3,5-7,13]$.

Padronizado pela norma DIN 8580, o forjamento é um processo com quinze sub-processos. A norma DIN 8583 o define como processo de conformação por tensão compressiva, sendo subdivididos quanto à temperatura de trabalho, definindo-se: conformação a frio, conformação a morno e conformação a quente $[3,5,6,14,16]$. Mesmo que, por convenção, costuma-se dizer que forjamento é realizado a quente, em geral é necessário definir a temperatura de trabalho para se distinguir o tipo de forjamento [3,14]. Para classificar o forjamento quanto a temperatura se utiliza a temperatura homóloga, a qual varia entre 0 e 1 . Sendo 0 o zero absoluto e 1 a temperatura de fusão do material [14]. Desta forma, o forjamento a frio é realizado até 0,3 da temperatura homóloga, o forjamento a morno dá-se entre 0,3 e 0,5 e o forjamento a quente entre 0,5 e 1,0 da temperatura homologa $[9,14]$.

Independentemente se realizada a quente, a frio ou a morno, a deformação plástica e a recuperação elástica, comumente considerada desprezível, são as características principais encontradas em qualquer tipo de forjamento [3,14,17]. A Tabela 1 apresenta o comparativo entre os tipos de forjamento: forjamento a frio, forjamento a morno e forjamento a quente, mostrando as capacidades e limitações de cada um deles [18]. 
Tabela 1 - Comparativo das capacidades e limitações dos tipos de forjamento (Adaptado de [18]).

\begin{tabular}{|c|c|c|c|}
\hline & Forjamento a Quente & Forjamento a Frio & Forjamento a Morno \\
\hline Tolerância & IT 12 - IT 16 & IT 7 - IT 11 & IT 9 - IT 12 \\
\hline Peso das peças conformadas & $0,005-1500 \mathrm{~kg}$ & $0,001-50 \mathrm{~kg}$ & $0,100-50 \mathrm{~kg}$ \\
\hline Lotes econômicos (massa $1 \mathrm{~kg}$ ) & Mín. 500 peças & Mín. 3000 peças & Mín. 1000 peças \\
\hline Aços conformáveis & Todos & $\begin{array}{l}\text { Aços de baixa liga }(\mathrm{C}<0,45 \% \\
\text { outros elementos }<3 \%)\end{array}$ & $\begin{array}{l}\text { Aços com teores de elementos de } \\
\text { liga }<10 \%\end{array}$ \\
\hline Formas & Todas sem reentrâncias & $\begin{array}{l}\text { Principalmente axissimétricas sem } \\
\text { reentrâncias }\end{array}$ & $\begin{array}{l}\text { Axissimétricas são desejáveis, } \\
\text { sem reentrâncias }\end{array}$ \\
\hline Conformabilidade $(\varphi)$ & Normalmente não há limite & Razão de deformação $\varphi<1,6$ & $\begin{array}{l}\text { Razão de deformação } \varphi>1,6 \\
\text { (limite superior depende da } \\
\text { composição química do aço e da } \\
\text { temperatura de forjamento) }\end{array}$ \\
\hline Qualidade superficial & $>100 \mu \mathrm{m}$ & $\approx 10 \mu \mathrm{m}$ & $<50 \mu \mathrm{m}$ \\
\hline Possibilidade de automação & Limitada & Adequada & Vantajosa \\
\hline Tratamento superficial & Não é necessário & Recozimento, fosfatização & $\begin{array}{l}\text { Normalmente não há tratamento } \\
\text { superficial }\end{array}$ \\
\hline Tratamento intermediário & Não é necessário & Recozimento, fosfatização & Normalmente não é necessário \\
\hline Vida da matriz & $2.000-5.000$ peças & $20.000-50.000$ peças & $10.000-20.000$ peças \\
\hline $\begin{array}{l}\text { Custo para desenvolvimento e } \\
\text { construção de ferramentas }\end{array}$ & Baixo & Médio & Alto \\
\hline
\end{tabular}

ALTAN et al. [3] consideram o forjamento como um sistema que une sete variáveis complexas: 1 - blank, 2 - ferramental, 3 - interface ferramenta/blank, 4 zona de deformação, 5 - equipamento, 6 - produto e 7 - ambiente/máquina. A interação perfeita destas variáveis visa obter produtos sem defeitos, onde haja o preenchimento completo da gravura da ferramenta, favorecido pelo fluxo de material correto $[5,6]$. 
O fluxo de material correto favorece o forjamento "net shape" , o qual é considerado como uma técnica avançada de conformação, visa obter produto forjado com o menor sobremetal possível [3,5]. Dessa forma, a quantidade de matéria-prima necessária ao forjamento é reduzida, assim como os processos de transformação seguintes, tais como usinagem ou outras etapas de fabricação, sem prejuízo na aplicação do produto [3,6]. Para produzir produtos "net shape" com elevada qualidade, repetibilidade, com propriedades mecânicas superiores e que possibilitem redução de processos de transformação e custos de fabricação, é necessário fazer-se uma seleção adequada de equipamentos e ferramentas de forjamento $[3,5-7,12,13]$.

\subsubsection{Equipamentos de forjamento}

Os equipamentos utilizados no forjamento passaram por grandes mudanças ao longo dos anos, deixando de lado as ferramentas mais básicas, martelo e bigorna, para ser realizado por ferramentas e máquinas avançadas. Hoje, os equipamentos mais modernos contam com muitos dispositivos eletrônicos de controle que permitem ajustes precisos dos parâmetros de forjamento $[5,8]$.

As máquinas utilizadas no forjamento são classificadas em três grupos, de acordo com: energia máxima disponível, força máxima disponível e deslocamento do ferramental, conforme apresentado no diagrama da Figura 4 [3,5].

\footnotetext{
${ }^{3}$ Conceito "net shape" de forjamento é o que há de mais avançado em projeto de produto forjado e projeto de ferramentas. Neste conceito o produto forjado é concebido com o menor sobremetal possível a fim de obter produtos com menor peso e sobremetal. Este conceito beneficia diretamente o produto, sua aplicação e o processo produtivo.
} 


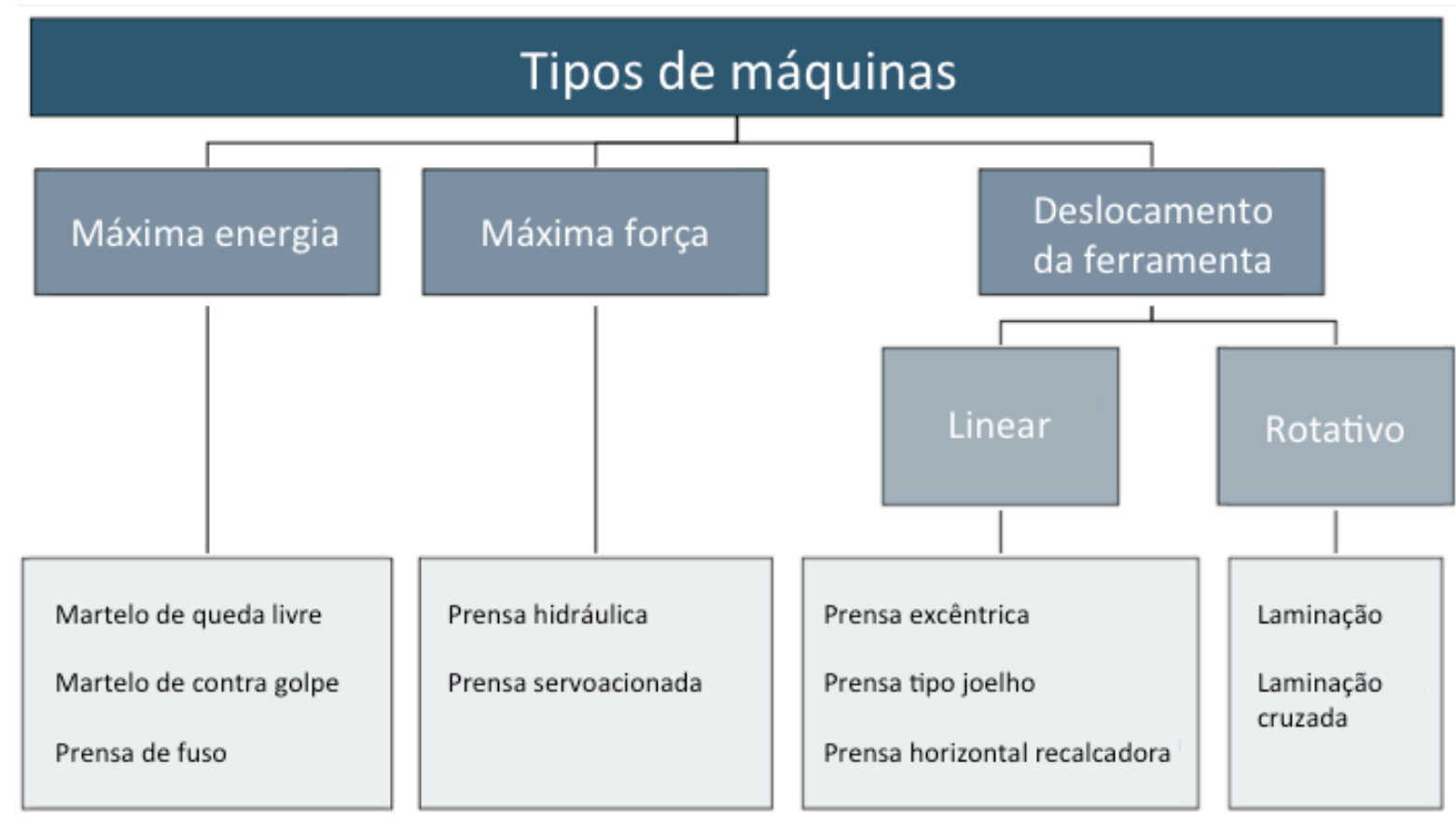

Figura 4 - Diagrama de tipos de máquinas existentes [18].

Independentemente do tipo de equipamento utilizado no forjamento, a utilização das ferramentas é indispensável para a obtenção dos produtos forjados e estas desempenham um papel importantíssimo na produção de produtos seriados de elevada demanda anual $[3,5,6,19]$.

\subsubsection{Ferramentas}

O uso das ferramentas varia conforme o tipo de equipamento utilizado no forjamento e a geometria do produto. Dependendo do tipo de equipamento a quantidade de ferramentas pode ser alterada, utilizando mais ou menos ferramentas. Como por exemplo, punções, matrizes, extratores, buchas, garras e insertos [19-21].

Inicialmente, as ferramentas eram fabricadas em aço e suas composições químicas não indicavam elementos de liga como os utilizados atualmente $[5,14,20,22,23]$. No entanto, a partir do século XIX, diversos estudos e desenvolvimentos foram realizados, resultando na modificação da quantidade e tipo de elementos de liga nos aços, possibilitando a criação de novos materiais com propriedades superiores, que hoje são conhecidas como aços-ferramenta $[5,14,19,20,22,23]$. Os diferentes aços-ferramenta são divididos conforme a concentração dos elementos de liga utilizados na composição química. Os aços- 
ferramenta ligados ao cromo (Cr), ao tungstênio (W) e os aços baixa liga são os mais comuns e estão destacados, junto com as suas composições químicas, nas Tabela 2, Tabela 3 e Tabela 4. No entanto, convém igualmente citar os açosferramenta ligados ao molibdênio (Mo), da série $\mathrm{H}-41-\mathrm{H}-43$, e de média liga, da série A2-A9 [5,17,20,21].

Tabela 2 - Composição química dos aços-ferramentas com base em cromo - AISI [5].

\begin{tabular}{|c|c|c|c|c|c|c|c|c|c|}
\hline Aço & C & Mn & Si & Co & Cr & Mo & Ni & V & W \\
\hline H-10 & 0,40 & 0,40 & 1,00 & - & 3,30 & 2,50 & - & 0,50 & - \\
\hline H-11 & 0,35 & 0,30 & 1,00 & - & 5,00 & 1,50 & - & 0,40 & - \\
\hline H-12 & 0,35 & 0,40 & 1,00 & - & 5,00 & 1,50 & - & 0,50 & 1,50 \\
\hline H-13 & 0,38 & 0,30 & 1,00 & - & 5,25 & 1,50 & - & 1,00 & - \\
\hline H-14 & 0,40 & 0,35 & 1,00 & - & 5,00 & - & - & - & 5,00 \\
\hline H-19 & 0,40 & 0,30 & 0,30 & 4,25 & 4,25 & 0,40 & - & 2,10 & 4,10 \\
\hline
\end{tabular}

Tabela 3 - Composição química dos aços-ferramentas com base em tungstênio - AISI [5].

\begin{tabular}{|c|c|c|c|c|c|c|c|c|c|}
\hline Aço & C & Mn & Si & Co & Cr & Mo & Ni & V & W \\
\hline H-21 & 0,30 & 0,30 & 0,30 & - & 3,50 & - & - & 0,45 & 9,25 \\
\hline H-22 & 0,35 & 0,30 & 0,30 & - & 2,00 & - & - & 0,40 & 11,00 \\
\hline H-23 & 0,30 & 0,30 & 0,30 & - & 12,00 & - & - & 1,00 & 12,00 \\
\hline H-24 & 0,45 & 0,30 & 0,30 & - & 3,00 & - & - & 5,00 & 15,00 \\
\hline H-25 & 0,25 & 0,30 & 0,30 & - & 4,00 & - & - & 5,00 & 15,00 \\
\hline H-26 & 0,50 & 0,30 & 0,30 & - & 4,00 & - & - & 1,00 & 18,00 \\
\hline
\end{tabular}

Tabela 4 - Composição química dos aços-ferramenta baixa liga - AISI [5].

\begin{tabular}{|c|c|c|c|c|c|c|c|c|c|}
\hline Aço & C & Mn & Si & Co & Cr & Mo & Ni & V & W \\
\hline ASM6G & 0,55 & 0,80 & 0,25 & - & 1,00 & 0,45 & - & 1,00 & - \\
\hline ASM6F2 & 0,55 & 0,75 & 0,25 & - & 1,00 & 0,30 & 1,00 & 0,10 & - \\
\hline
\end{tabular}

Os materiais empregados na fabricação de ferramentas de forjamento devem suportar altos esforços e resistir às mais diferentes cargas. Logo, devem possuir propriedades de resistência mecânica a quente, resistência à abrasão a quente, tenacidade, resistência à fadiga, condutividade térmica e resistência à formação de trincas térmicas, pois deverão suportar todas as cargas, o contato com o blank de aço que será forjado e o aquecimento durante o forjamento [3,5,6,20,24]. 


\subsection{Tribologia}

O contato entre duas superfícies, como por exemplo a ferramenta e o blank, é estudado pela tribologia. Esta ciência recebeu este nome em um comitê do departamento de educação e ciências britânico no ano de 1966. É uma área da engenharia desafiadora e multidisciplinar, pois estuda o movimento relativo entre duas superfícies envolvendo competências de química, física, metalurgia e mecânica [25,26]. O termo tribologia vem da aglutinação das palavras gregas "tribos", a qual significa atrito ou deslizamento, e da palavra grega "logia", a qual significa estudo. Portanto, tribologia é o estudo do movimento relativo entre superfícies e do contato entre elas [26-28]. Números de 1990 apontavam que eram gastos valores entre 1,3\% e 1,6\% do Produto Interno Bruto - PIB do Reino Unido devido ao desgaste de componentes e sistemas. Entretanto, cerca de $20 \%$ deste montante poderia ser evitado com certa facilidade caso houvesse capacitação e treinamento de engenheiros em tribologia [19,25,26].

A tribologia está envolvida em qualquer sistema que relacione contato entre substâncias e superfícies, desde o simples contato das superfícies de um ralador de cozinha ralando o alimento, até um complexo contato de um pneu de borracha de um Fórmula 1 rolando sobre o asfalto durante uma corrida [19]. A interação das superfícies em contato com as substâncias que estão entre elas e o meio que as circundam, recebe o nome de tribossistema [19,26-28]. A norma DIN 50320 classifica o tribossistema padrão, com um par de superfícies em contato, como contendo os seguintes componentes: a) corpo, b) contra-corpo, c) meio interfacial e d) meio circunvizinho. ZUM GAHR [29], propôs o desenho esquemático apresentado na Figura 5 para exemplificar o que a norma alemã padronizou.

Onde:

a) Corpo é o objeto de estudo;

b) Contra-corpo é o objeto que está sujeito às ações do corpo; 
c) Meio interfacial é a substância ou objeto que consegue estar presente entre as superfícies em contato do corpo e do contra-corpo;

d) Meio circunvizinho é o que está nas imediações do corpo e do contracorpo e, de certa forma, interage com eles.

\section{Tribossistema}

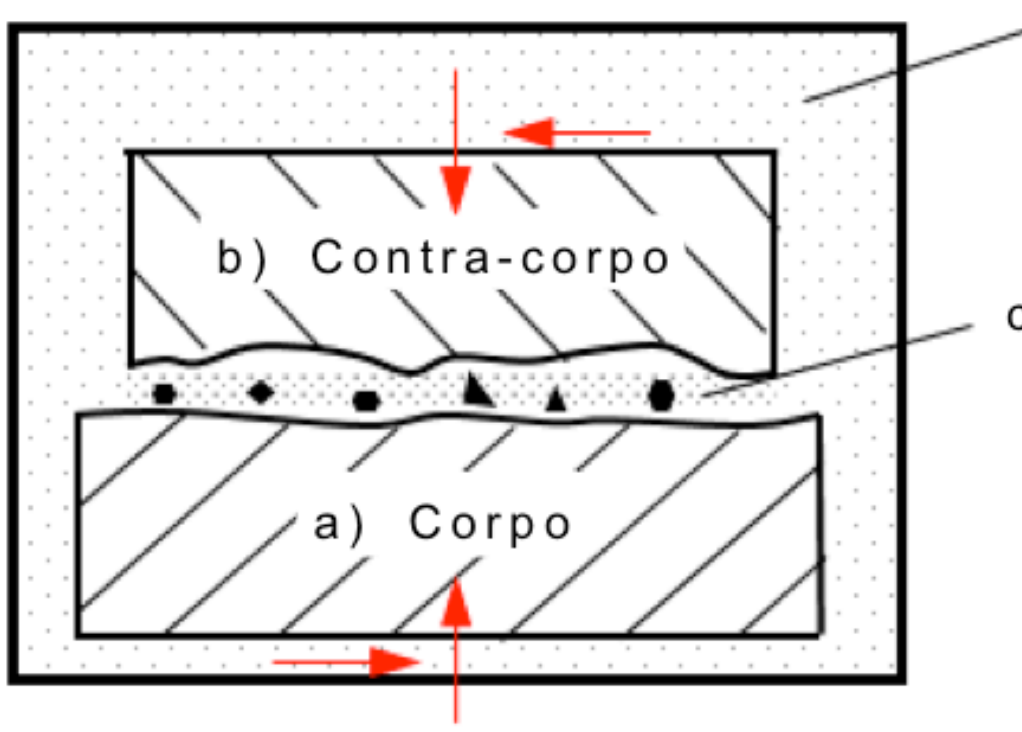

c) Meio circunvizinho

c) Meio interfacial

Figura 5 - Tribossistema genérico para qualquer par de superfícies em contato (Adaptado de [29]).

No forjamento o tribossistema costuma variar de acordo com o processo ou máquina utilizada, possibilitando a formação de tribossistemas diferentes. Utilizandose o tribossistema proposto por ZUM GAHR [29], ALTAN [3] e LANGE [6] afirmam que o tribossistema mínimo necessário para dar-se o forjamento é composto por quatro elementos: a) ferramenta; b) material; c) meio circunvizinho; d) meio interfacial. A Figura 6 exemplifica esta configuração genérica de tribossistema. 


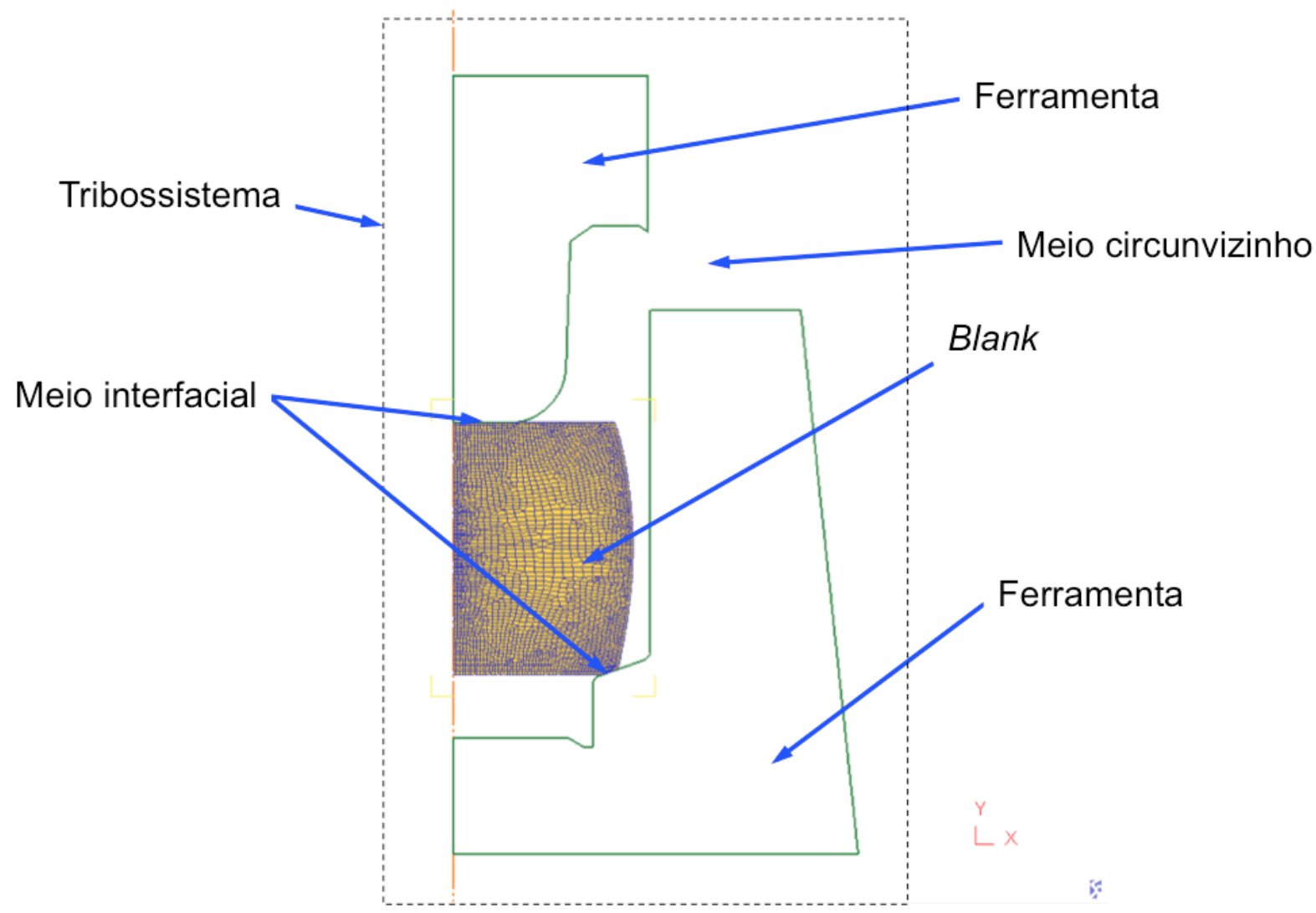

Figura 6 - Tribossistema padrão do forjamento a quente.

\subsubsection{Adesão}

Este modelo de desgaste, é associado à adesão de partículas ou substâncias às superfícies devido à afinidade química entre os materiais e os parâmetros físicos que a favorecem [27,28]. Seu comportamento é peculiar e geralmente resulta em elevada instabilidade de coeficiente de atrito porque a configuração da superfície costuma se alterar muito rapidamente [28,30].

Quanto em contato, as superfícies formam elementos do tribossistema conhecidos como junções. Estas junções surgem a partir do contato dos picos das asperezas das superfícies durante determinado movimento relativo entre elas. A medida que a carga normal na região aumenta, o tamanho da junção também aumenta. Aliado a isto, a afinidade química dos materiais das superfícies pode favorecer a formação e aumento das junções [28,30]. 
O rompimento das junções pode tanto transferir material de uma superfície para a outra, quanto liberar partículas no meio interfacial do tribossistema [30]. Este fenômeno está exposto na Figura 7, que ilustra um contato normal de duas superfícies. Em (a), o material com menor força interatômica, o material "fraco", e o material com maior força interatômica, o material "forte", são aproximados. Em (b), as superfícies já em contato, ficam submetidas a forças interatômicas, devido à afinidade química, e também à pressão de contato. Em (c), após a separação das superfícies, observa-se a perda de material da superfície do material fraco para a superfície do material forte $[19,27,28,30]$.

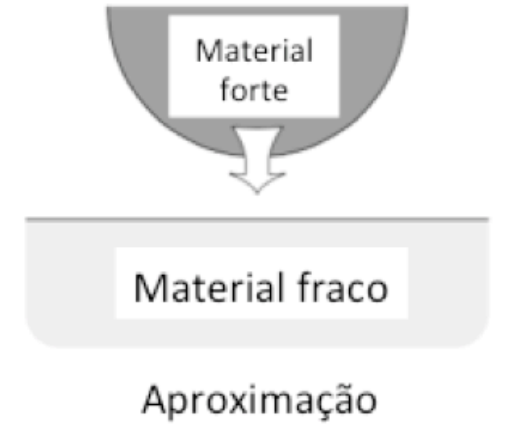

(a)

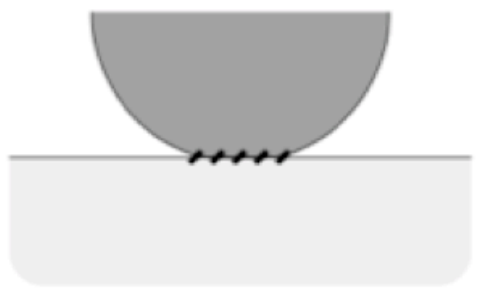

Adesão

(b)

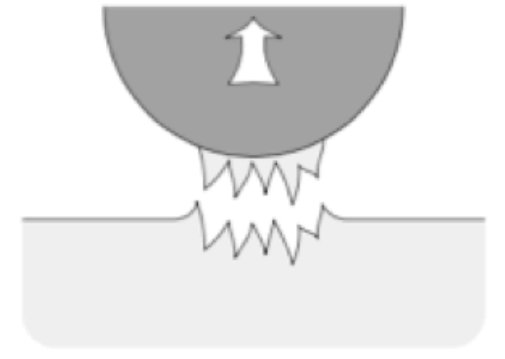

Transferência

(c)

Figura 7 - Formação da adesão (Adaptado de [28]).

Entre metais, a força interatômica entre superfícies é explicada pela ligação química do tipo metálica e pela consequente transferência de elétrons entre as superfícies em contato [28].

ABACHI [10], usou o modelo de Archard para descrever por meio de uma figura, a relação da área de contato com a dimensão da junção formada. A Figura 8 esquematiza a junção formada quando uma aspereza com diâmetro 2a é colocada em contato com outra superfície, sob a ação de uma força normal. Para haver esta formação, deve agir sobre a aspereza uma força normal $F_{N}$. A junção formada, somente seria rompida sob ação de uma força tangencial cisalhante, que surge devido ao movimento relativo entre as superfícies $A$ e $B$. 


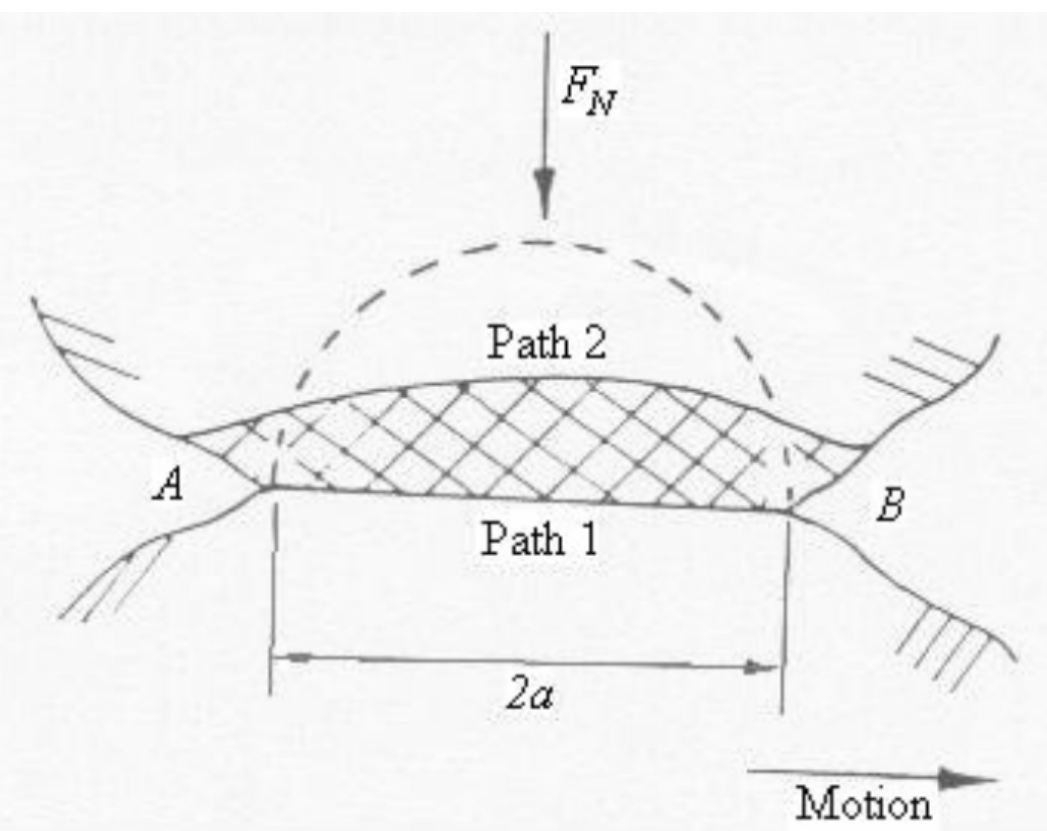

Figura 8 - Modelo de Archard para a formação de junções devido à adesão (Adaptado de [10]).

No forjamento a quente o processo de adesão é potencializado porque as altas temperaturas utilizadas favorecem a mobilidade atômica e a diminuição de algumas propriedades mecânicas. Em paralelo, a microestrutura dos corpos que entraram em contato pode influenciar no comportamento adesivo da junção formada [6].

Em um primeiro momento, a adesão não é responsável pela perda de material da ferramenta e pode, pelo contrário, evidenciar um ganho de massa repentino. Este ganho pode perdurar até que o material aderido seja transferido ou se desprenda, gerando a redução da massa. STACHOVIAK e BATCHELOR [28] apresentaram uma sequência de ilustrações que exemplificam a formação da partícula aderida nas superfícies [28]. Nesta formação há a mistura de partículas de ambas as superfícies do tribossistema sob a ação da pressão e do movimento relativo sofrido pelas superfícies, denominada formação lamelar. A Figura 9 mostra os quatro estágios da evolução da partícula. Em (a) tem-se o aparecimento de uma partícula contento fragmentos de ambas as superfícies. Em (b) a partícula é pressionada contra as superfícies e adquiri uma área "A" de contato. Em (c), devido ao movimento relativo entre as superfícies e ainda sob pressão, a partícula é alongada, levando a uma área de contato maior que a área " $A$ " inicial. Neste momento percebe-se a mistura e sobreposição das partículas das superfícies. Em 
(d), a partícula ora alongada, agora apresenta morfologia lamelar bem definida e, além de ter uma área maior que a área inicial "A", apresenta maior volume. Em (e), tem-se uma imagem obtida por microscopia eletrônica de varredura, na qual observa-se uma partícula solta de materiais aderidos com morfologia lamelar.

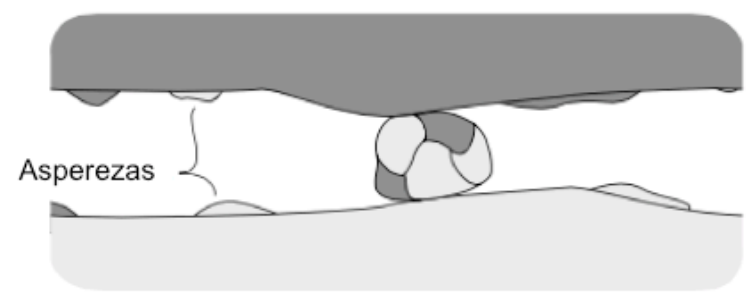

a) Estágio inicial de crescimento da partícula aderida

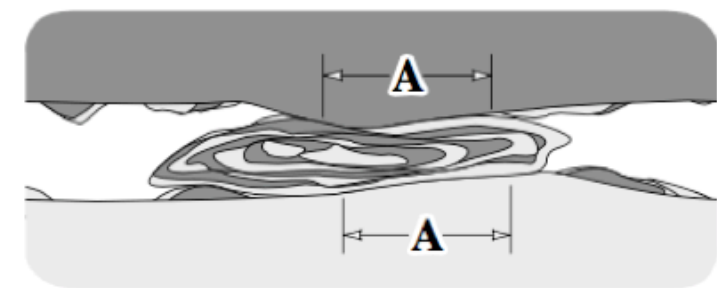

c) Partícula aderida sob pressão e movimento relativo

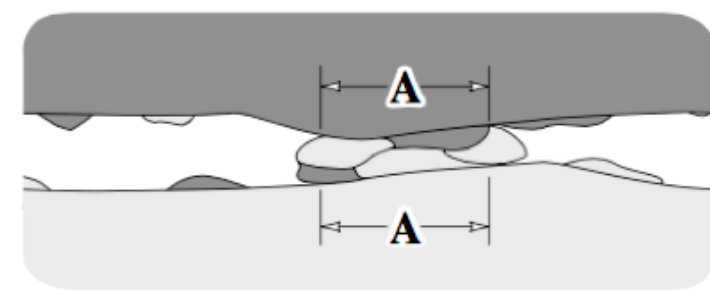

b) Partícula aderida pressionada com área de contato $\mathrm{A}$

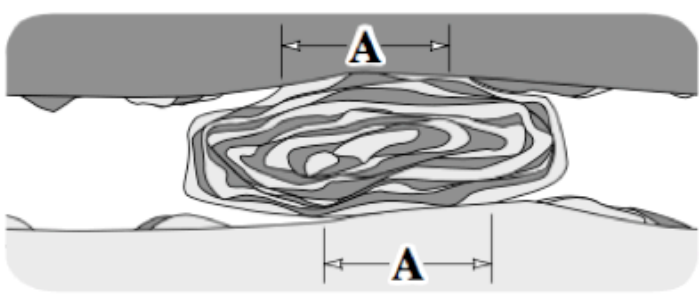

d) Crescimento da partícula aderida antes de ser removida

e) Partícula aderida

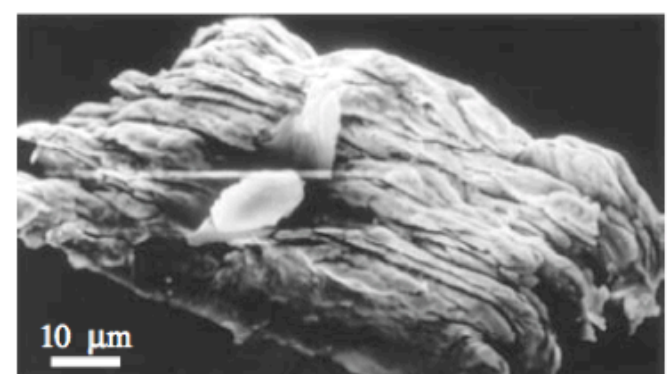

Figura 9 - Morfologia lamelar das partículas aderidas soltas no tribossistema (Adaptado de [28]).

Quando as partículas aderidas são cisalhadas e não são removidas da interface, os debris podem resultar em desgaste abrasivo [6,19,27,28]. A Figura 10 apresenta um exemplo de material aderido à superfície e que, devido ao movimento relativo, cria um sulcamento. Nesta sequência de eventos, o desgaste inicialmente adesivo torna-se desgaste abrasivo. No sulco formado existe também a formação de trincas perpendiculares à direção de movimento da partícula. 


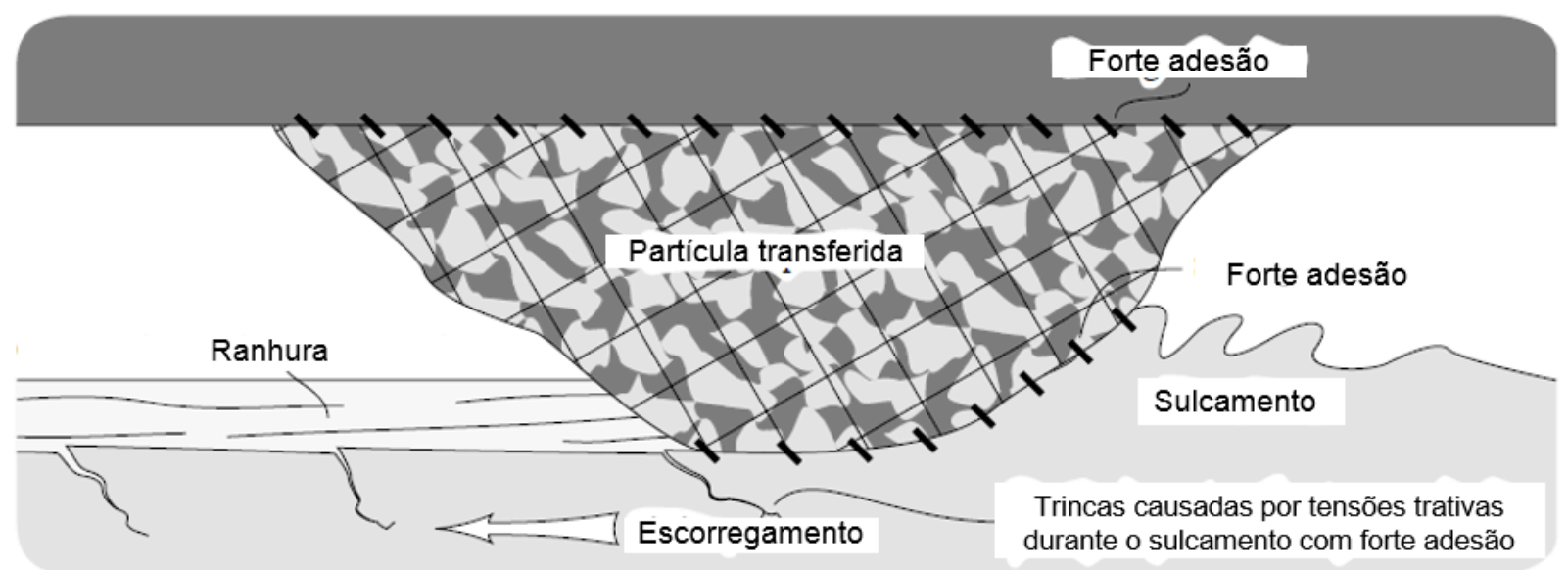

Figura 10 - Mecanismo de desgaste - Sulcamento por partículas aderidas (Adaptado de [28]).

\subsubsection{Abrasão}

A abrasão é o resultado da movimentação relativa entre duas superfícies na presença de partículas abrasivas que são forçadas contra ao menos uma das superfícies, resultando na perda de material [5,6,21,31,32,33]. A literatura classifica a abrasão quanto ao número de corpos envolvidos no tribossistema e quanto ao nível de esforços $[27,28,31,32,33]$.

A classificação da abrasão quanto a quantidade de corpos envolvidos no tribossistema, a dois ou a três corpos, teve sua primeira proposta feita por BURWELL [34]. Se as partículas ou asperezas estão presas a uma das superfícies é considerada abrasão a dois corpos, Figura 11 (a) [27,28,34-36]. No caso das asperezas estarem soltas no meio interfacial, a abrasão é considerada a três corpos, Figura 11 (b) $[27,28,35-37]$. 

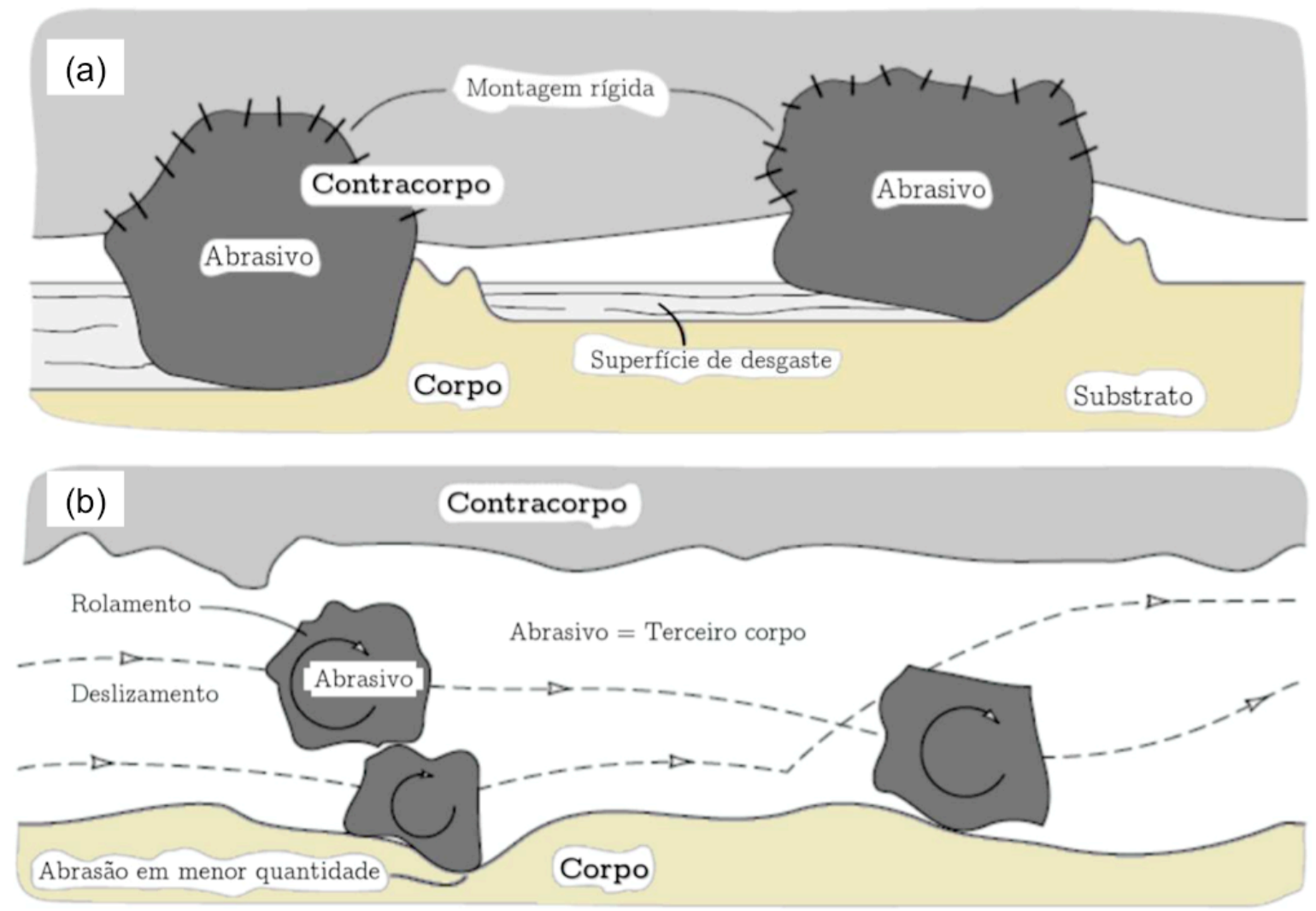

Figura 11 - Classificação da abrasão quanto à quantidade de corpos envolvidas no tribossistema (a) abrasão a dois corpos e (b) abrasão a três corpos [36].

GATES [35] e TREZONA [37] utilizaram a proposta feita por BURWELL [34] para apresentar um novo modelo para a abrasão a três corpos [34,35,37]. Neste modelo os autores classificam o desgaste abrasivo quanto à cinemática do movimento das partículas abrasivas soltas no meio interfacial do tribossistema. Neste caso, diferenciam-se o rolamento ou deslizamento do abrasivo sobre a superfície como responsáveis pelo desgaste abrasivo a três corpos [34,35,37].

Em ferramentas de forjamento a quente o modelo a três corpos representa um fenômeno encontrado na interface do tribossistema [6,20,31,38,39]. Neste caso, os terceiros corpos, ou seja, as partículas soltas no meio interfacial podem ser óxidos do blank, óxidos da ferramenta ou carbonetos desprendidos da superfície da ferramenta $[6,29,40]$. Na Figura 12 observa-se uma ferramenta de forjamento a quente desgastada, na qual evidências de abrasão foram destacadas pelas setas 
vermelhas, na região do patamar de rebarba ${ }^{4}$. Esta região da ferramenta está sujeita ao maior fluxo de material devido ao escoamento do excesso de matéria prima para a rebarba.

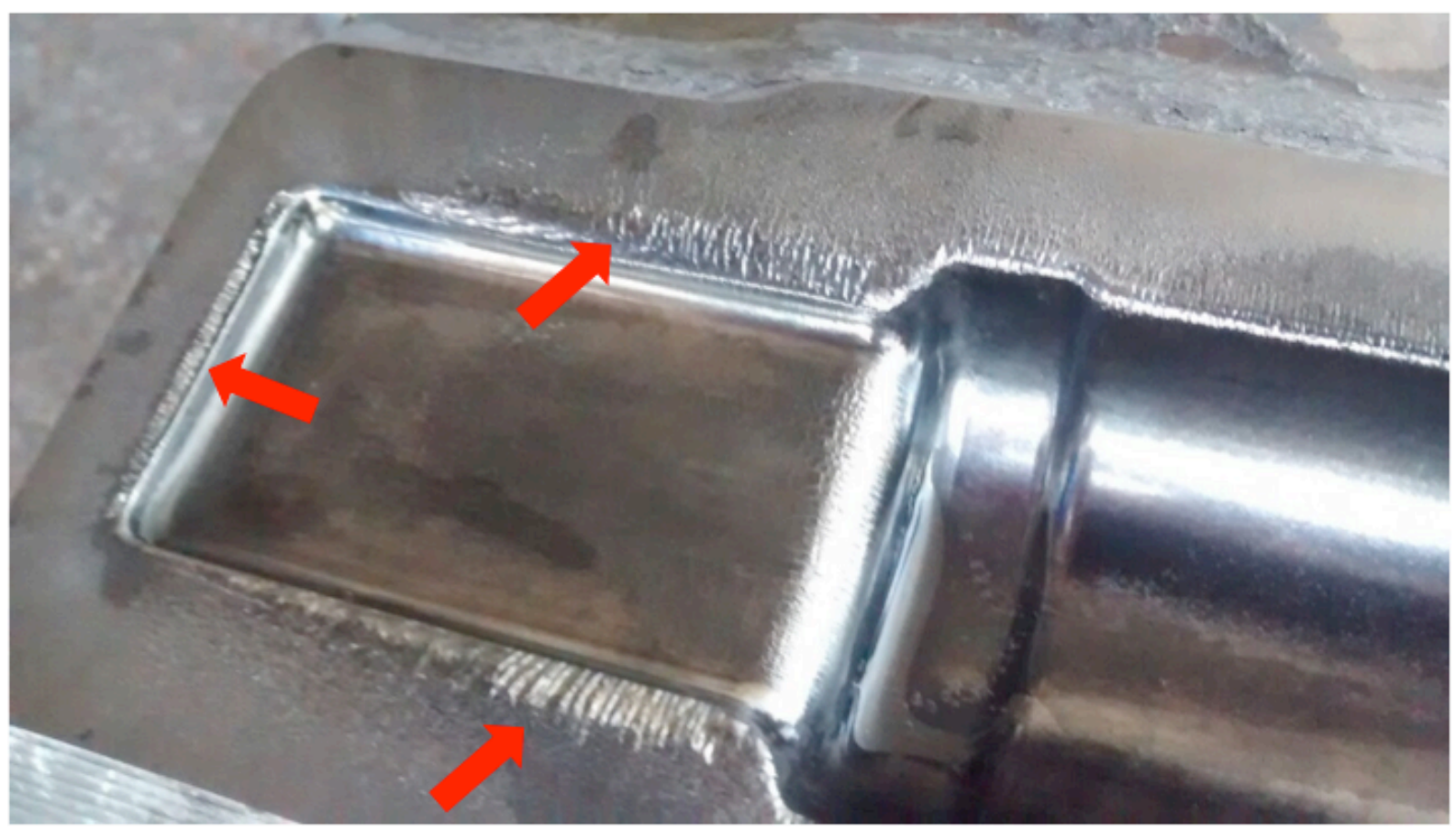

Figura 12 - Desgaste abrasivo em matriz de forjamento a quente com rebarba em prensa vertical ${ }^{5}$.

A abrasão causada na superfície de ferramentas pode ser causada por cinco mecanismos diferentes, embora, segundo HUTCHINGS, não há uma fronteira bem definida para os diferenciar $[27,28,39]$. No entanto, é possível verificar a ligeira diferença entre os três e comparar com os outros dois mecanismo utilizando as duas figuras a seguir. Na Figura 13, em (a) tem o sulcamento, em (b), o sulcamento é mais profundo e ocasiona a deformação plástica, para as laterais, na região percorrida pela aspereza, e para frente da aspereza. Este mecanismo pode não ocasionar a perda de material. A diferença entre as duas condições apresentadas em (a) e em (b) é a intensidade do dano provocado à superfície. Em (c), observa-se

\footnotetext{
${ }^{4}$ Patamar de rebarba é a região da ferramenta devidamente projetada para o escoamento da rebarba de material. Esta região da ferramenta é calculada para resfriar o material que escoa sobre ela gerando resistência ao escoamento e, desta forma, favorecer o preenchimento das cavidades da matriz com a menor quantidade de material possível.

${ }^{5} \mathrm{~A}$ imagem da matriz de forjamento a quente é uma cortesia da Neumayer Tekfor Automotive Brasil Ltda.
} 
o mecanismo de corte. Este comportamento causa a ruptura do material da superfície e a consequente perda de material.

a) sulcamento
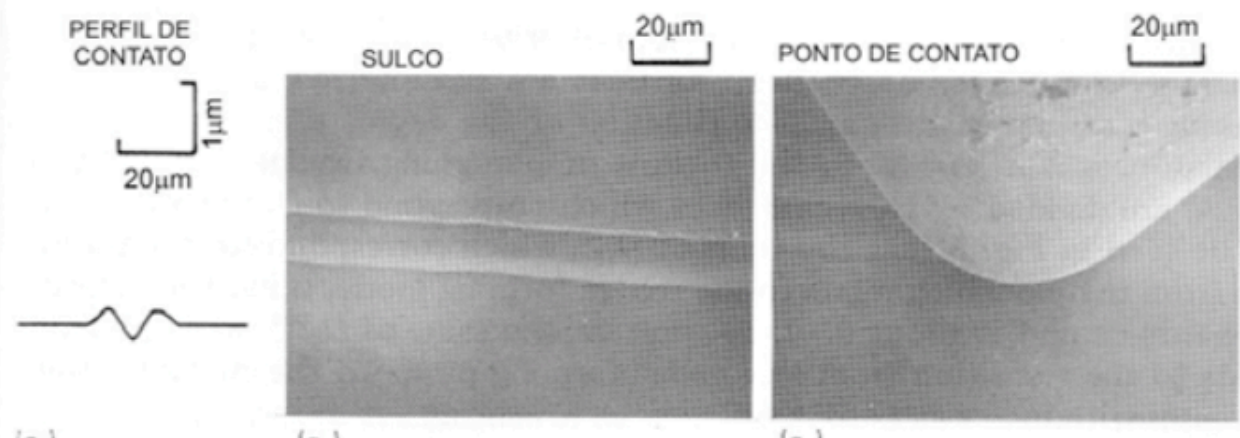

b) formação de proa

c) corte

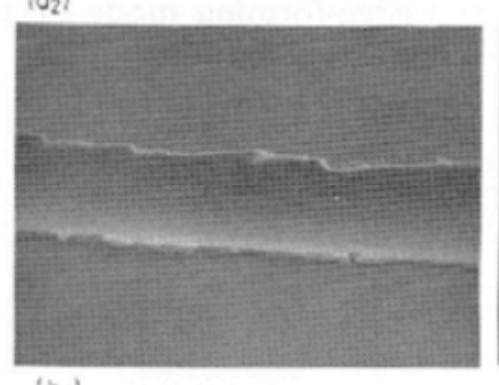

$\left(0_{3}\right)$

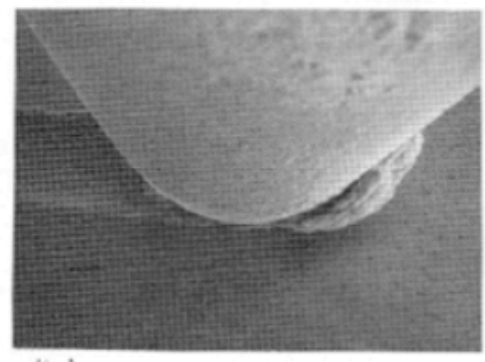

$(b y)$
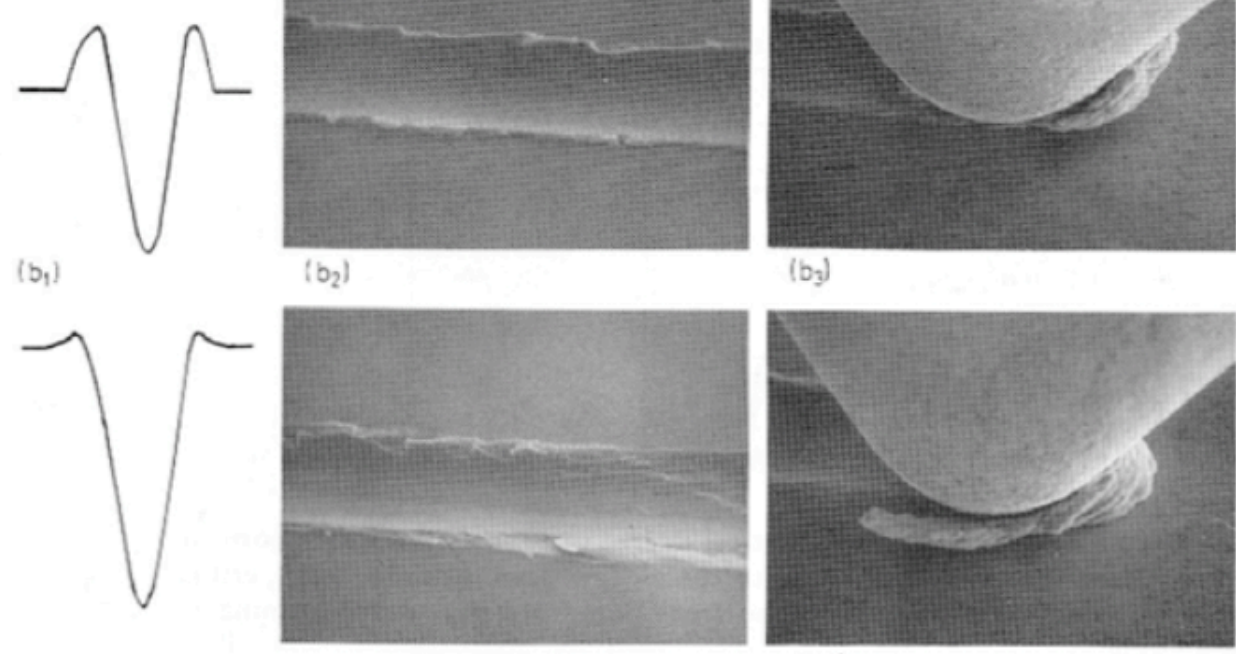

$\left(c_{1}\right)$

$\left(c_{2}\right)$

$\left(c_{3}\right)$

Figura 13 - Mecanismos de desgaste abrasivo por deslizamento da aspereza [39].

O quarto e o quinto mecanismos estão relacionados à fadiga da superfície causada pela carga e movimento da partícula abrasiva [27,28]. A Figura 14 apresenta os dois mecanismos no qual, em (a) há o exemplo de fratura causada pela impressão da aspereza na superfície onde surgem trincas e elas se propagam até a ruptura. Em (b) é mostrado o mecanismo de desplacamento do grão que é causado quando a aspereza encontra um substrato mais duro disperso em uma matriz mais mole e o choque causado pela aspereza remove o grão inteiro da matriz. 


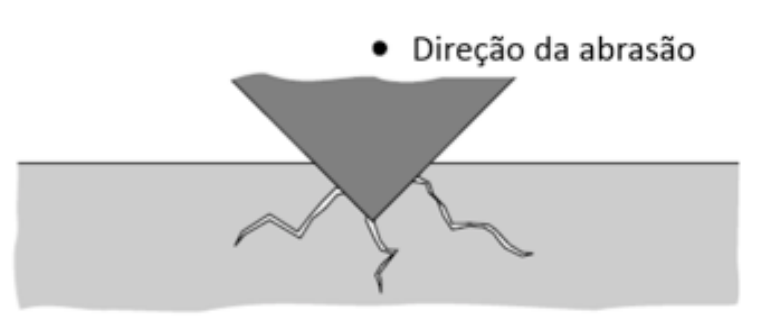

a) Fratura

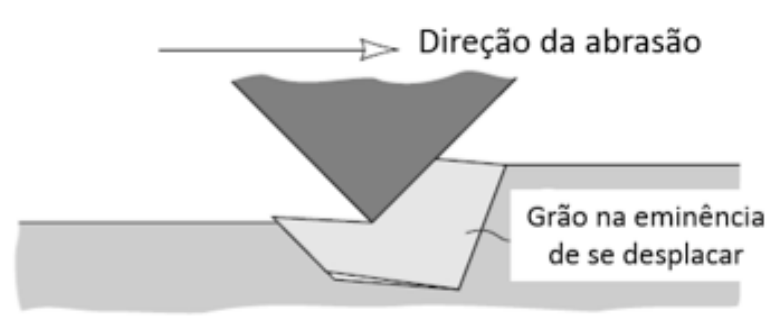

b) Desplacamento

Figura 14 - Mecanismo de desgaste abrasivo (Adaptado de [28]).

\subsubsection{Fadiga mecânica}

A fadiga mecânica é um processo evolutivo que resulta no colapso e perda de integridade de uma determinada geometria. Algumas características do processo de forjamento, como altas cargas aplicadas ciclicamente favorecem a ocorrência deste fenômeno. No entanto é um aspecto que pode ser trabalhado com alterações do projeto da ferramenta e com os materiais utilizados na fabricação $[12,27,28]$.

O processo de evolução da fadiga mecânica envolve a nucleação e a propagação de trincas que, ao longo da vida da ferramenta, pode levar à fratura catastrófica. A Figura 15 apresenta uma trinca que nucleou e se propagou em uma matriz de forjamento a quente no raio de concordância de duas arestas [12].

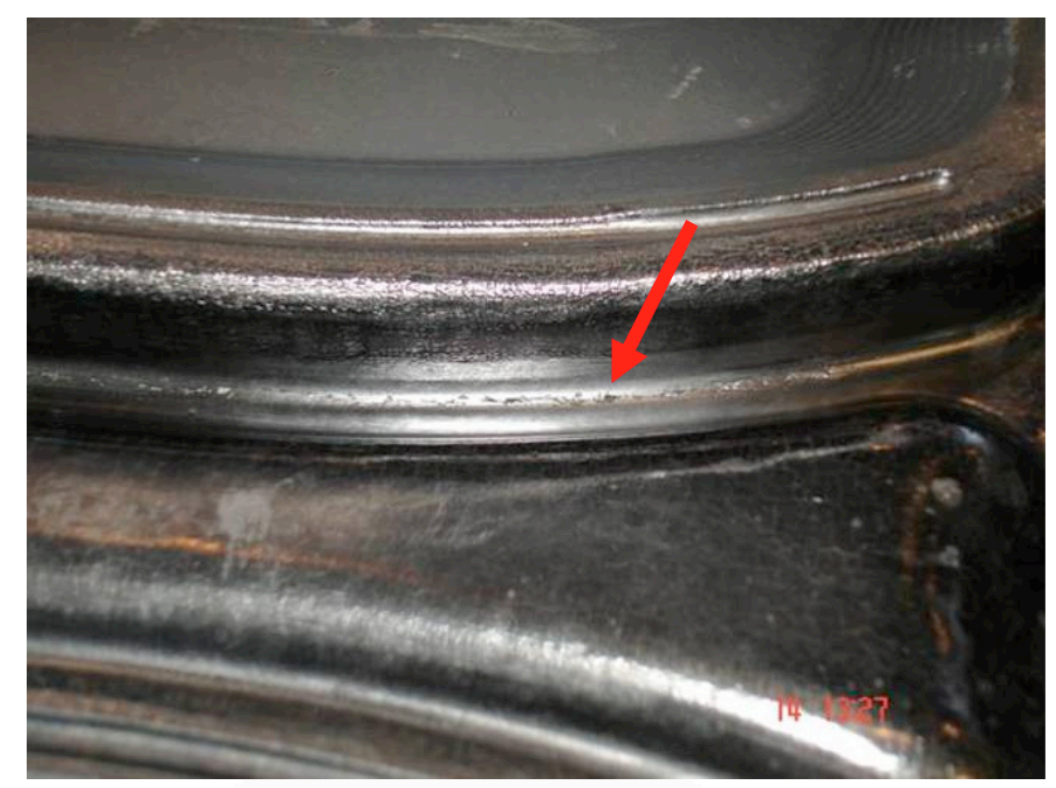

Figura 15 - Trinca proveniente de fadiga mecânica em matriz de forjamento a quente de biela automotiva [12]. 


\subsubsection{Fadiga Térmica}

No forjamento a quente, a temperatura na qual o material será conformado potencializa o surgimento da fadiga térmica nas ferramentas e ela é inerente a este tipo de forjamento. Desde o primeiro contato entre o blank com a ferramenta até a conclusão da operação de forjamento, a temperatura da interface aumenta bruscamente. Quando a operação o forjamento é finalizado e não há mais o contato entre os dois a temperatura da interface volta a diminuir e esta sequência de eventos com variação de temperatura causa o surgimento de um gradiente térmico na ferramenta. No gradiente formado, a maior temperatura é encontrada na superfície das ferramentas e a menor temperatura é encontrada no núcleo [30].

A variação da temperatura causa a expansão e contração da ferramenta, o que consequentemente resulta no surgimento de tensões alternadas de tração e compressão $[30,41]$. As tensões alternadas, ao longo da utilização da ferramenta no forjamento, causam a nucleação de trincas na superfície das ferramentas que se propagam em direção ao núcleo [30,37,39,41].

ENGLUND et FORSSTRÖM [41] propuseram (Figura 16) uma ilustração do comportamento cíclico na microestrutura do aço da ferramenta durante os ciclos de aquecimento e resfriamento ao longo do forjamento a quente. Em (a), durante o aquecimento da ferramenta e durante o forjamento, a ferramenta se dilata e surgem tensões trativas. Em (b), durante o resfriamento e durante a lubrificação, a ferramenta se contrai ocasionando o surgimento de tensões compressivas. 

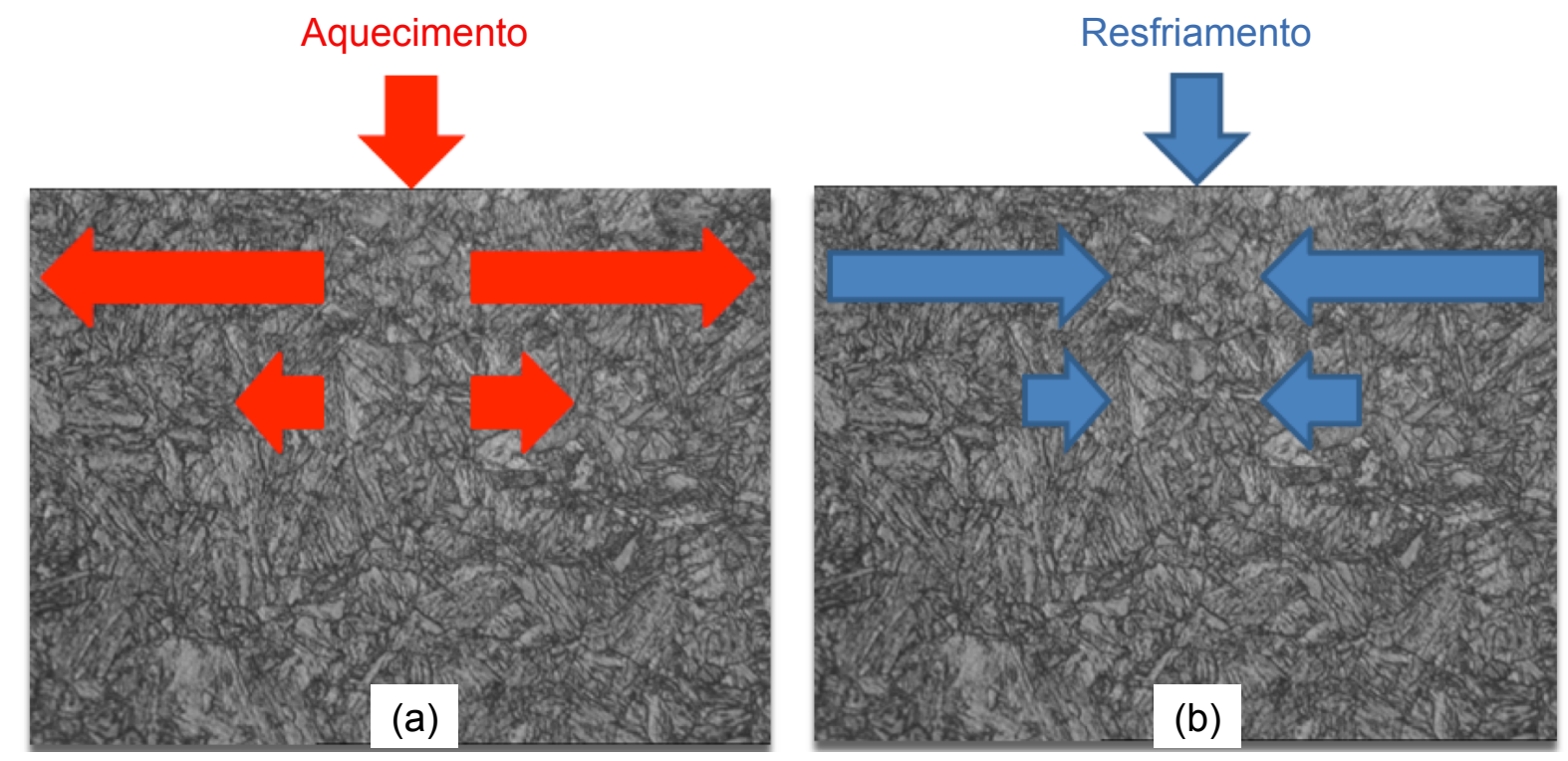

Figura 16 - Conceito esquemático da variação térmica. Em (a), expansão da microestrutura devido ao aquecimento. Em (b), contração devido ao resfriamento (Adaptado de [41]).

Conhecendo-se a mínima e a máxima temperaturas na ferramenta é possível estimar a fatiga de baixo ciclo utilizando a equação 4 [30].

$$
\alpha\left(T_{2}-T_{1}\right)>2 \frac{\left(1-v_{1}\right) \sigma}{E_{1}}+2 \frac{\left(1-v_{2}\right) \sigma}{E_{2}}
$$

Onde:

б: é a tensão;

T: é a temperatura;

a: é o coeficiente de expansão;

v: é o coeficiente de Poisson;

1 e 2: são índices que indicam a mínima e a máxima temperatura;

Já a nucleação de trincas ocorre quando o critério de Coffin-Manson é satisfeito e o número de ciclos para que ela ocorra pode ser estimado pela equação $5[30]$. 
$N_{F}^{n} \varepsilon_{P}=C \varepsilon_{f}$

Onde:

$\mathrm{N}$ : é o número de ciclos para nucleação da trinca;

$\mathrm{n}$ : é constante do material, variando de 0 até 1 ;

$\varepsilon_{\mathrm{p}}$ : é o campo de deformação plástica;

C: é uma constante que varia de 0 até 1 ;

$\varepsilon_{f}$ : é a deformação real para a fratura.

O crescimento da trinca, após a nucleação na superfície das ferramentas pode ser calculado pela equação 6 [30].

$\frac{d a}{d N}=a \rho\left(\varepsilon_{P}\right)^{q}=a \rho\left[\alpha\left(T_{2}-T_{1}\right)-\frac{\left(1-v_{1}\right) \sigma_{1}}{E_{1}}-\frac{\left(1-v_{2}\right) \sigma_{2}}{E_{2}}\right]^{q}$

Onde:

N: é o número de ciclos;

a: é o comprimento da trinca;

$\rho:$ constante função do material;

$\varepsilon_{\mathrm{p}}$ : é o campo de deformação plástica;

a: é o coeficiente de expansão;

T: é a temperatura;

q: constante função do material;

v: é o coeficiente de Poisson

1 e 2: são índices que indicam a mínima e a máxima temperatura 
Em resumo, as trincas são nucleadas, evoluindo da superfície para o interior da microestrutura, e se propagam até que encontrem outras, formando trincas maiores em forma de rede, apresentando um aspecto que se assemelha-se ao do leito de uma represa ou de um rio que secou [7,30,37,39,41,42]. A Figura 17 mostra a consequência da nucleação e propagação das trincas térmicas e compara a superfície da ferramenta com o leito de uma represa seca. Em (a), destacadas pelas setas vermelhas, as trincas causadas pela variação da temperatura e pelo consequente surgimento de tensões alternadas que se propagam até que encontram outras trincas [7]. Em (b) o exemplo da superfície de uma ferramenta de forjamento a quente com danos causados pela propagação de trincas provenientes da fadiga térmica [42]. Em (c), o leito da represa Jaguarí/Jacareí em Vargem/SP após um longo período de estiagem nos anos de 2014 e 2015, o qual se assemelha à superfície de uma ferramenta que sofreu danos térmicos [43].
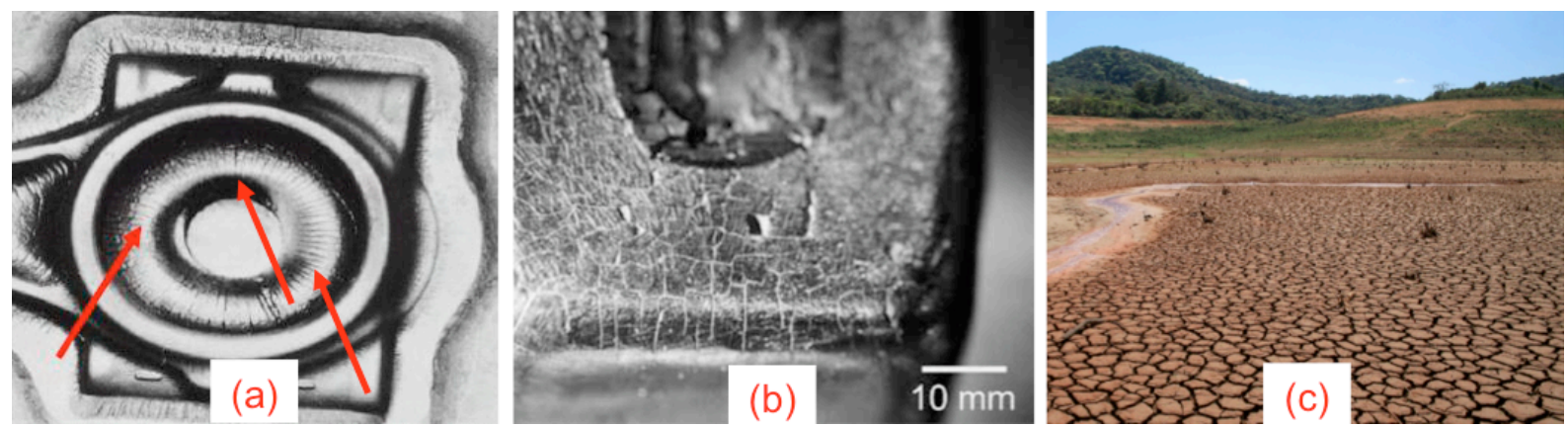

Figura 17 - Superfície da ferramenta afetada pela propagação de trincas térmicas em comparação com o leito de uma represa seca. (a) a superfície de uma matriz de forjamento de bielas automotivas com trincas térmicas [7]. (b), superfície de uma ferramenta de forjamento a quente com danos causados pela propagação de trincas provenientes da fadiga térmica [42]. (c), o leito da represa Jaguarí/Jacareí em Vargem/SP após um longo período de estiagem nos anos de 2014 e 2015 [43]

A temperatura da ferramenta e sua variação são variáveis importantes na determinação da vida da ferramenta devido a falha por fadiga térmica [44]. SJÖSTRÖM et BERGSTRÖM [42] já haviam mostrado influência da variação da temperatura na superfície da ferramenta. Ao longo de testes em corpos de prova ficou evidente que quanto maior a temperatura máxima na superfície, maior a deformação elástica causada pelo gradiente térmico. A Figura 18 mostra a comparação feita pelos autores SJÖSTRÖM et BERGSTRÖM correlacionando a deformação plástica com a temperatura na superfície da ferramenta durante o forjamento a quente [42]. Em (a), a temperatura máxima foi de $600^{\circ} \mathrm{C}$ e a deformação máxima foi de $0,14 \%$. Em (b), a temperatura máxima foi de $700^{\circ} \mathrm{C}$ e a deformação máxima foi de $0,18 \%$. 

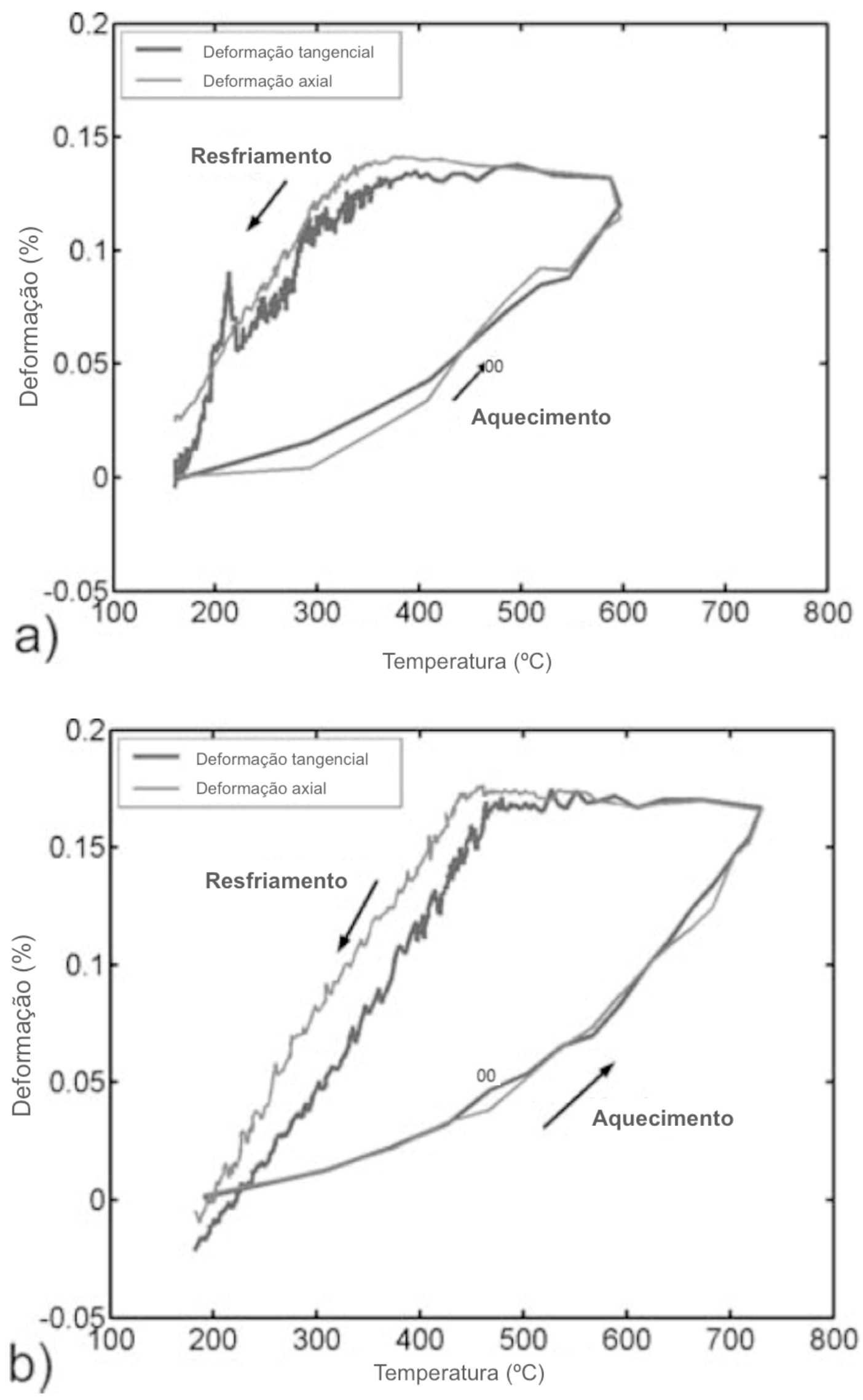

Figura 18 - Comparação da deformação plástica de um corpo de prova devido à máxima temperatura na superfície. (a) temperatura máxima $600^{\circ} \mathrm{C}$ e deformação máxima $0,14 \%$; (b) temperatura máxima $700^{\circ} \mathrm{C}$ e deformação máxima $0,18 \%$ (Adaptado de [42]). 
A observação dos resultados obtidos exclui a expectativa natural de comportamento linear de dependência entre temperatura e deformação. Ou seja, enquanto a temperatura foi até $17 \%$ maior, a deformação foi de 28,5\% [42]. SJÖSTRÖM et BERGSTRÖM ainda afirmam que além de serem os primeiros mecanismos de falha nas ferramentas, as trincas causadas por fadiga térmica surgem com cerca de $1 \%$ da vida útil da ferramenta e é responsável por $80 \%$ das falhas $[42,44]$.

Desta forma, quanto mais alta for a temperatura de forjamento, maior a chance da fadiga térmica causar o surgimento de trincas na microestrutura $[37,39,41,42]$. Em forma de tabela (Tabela 5), estão dispostas as maiores temperaturas necessárias para conformação a quente.

Tabela 5 - Temperaturas típicas de forjamento de materiais metálicos (Adaptado de [10]).

\begin{tabular}{|l|r|}
\hline \multicolumn{1}{|c|}{ Material } & \multicolumn{1}{|c|}{ Temperatura de forjamento $\left({ }^{\circ} \mathbf{C}\right)$} \\
\hline Ligas de magnésio & 370 \\
\hline Ligas de alumínio & 425 \\
\hline Ligas de cobre & 800 \\
\hline Aços ferramenta & 1000 \\
\hline Aços inoxidáveis & 1200 \\
\hline Aços carbono e aços microligados & 1260 \\
\hline
\end{tabular}

O forjamento de aços favorece gradientes térmicos mais altos, visto que a temperatura de forjamento é de cerca de $1260{ }^{\circ} \mathrm{C}$ e a temperatura média da ferramenta é de cerca de $200{ }^{\circ} \mathrm{C}[10,40,42,45]$. Exposta a estas altas temperaturas, a ferramenta está sujeita a uma rápida queda de dureza logo nos primeiros ciclos de forjamento seguida por uma queda gradual no restante da vida útil [46].

Para manter a temperatura das ferramentas muitos processos de forjamento utilizam lubrificantes como refrigerantes e para reduzir os esforços de conformação [3]. Ainda que na média a temperatura seja mantida, na superfície de contato com o blank a temperatura atinge valores bem maiores, podendo ultrapassar duas vezes a temperatura média da ferramenta. Esta lubrificação pode aumentar o gradiente térmico na superfície das ferramentas e potencializar o surgimento de trincas térmicas $[42,45,46]$. Alguns processos de forjamento, além de utilizarem lubrificantes sólidos, utilizam água ou mistura de água com lubrificantes dispersos para a 
refrigeração para as ferramentas, como mostra a Figura 19, onde é apresentada uma imagem da área de forjamento de uma prensa horizontal de múltiplos estágios com refrigeração forçada a base de água [5-8].

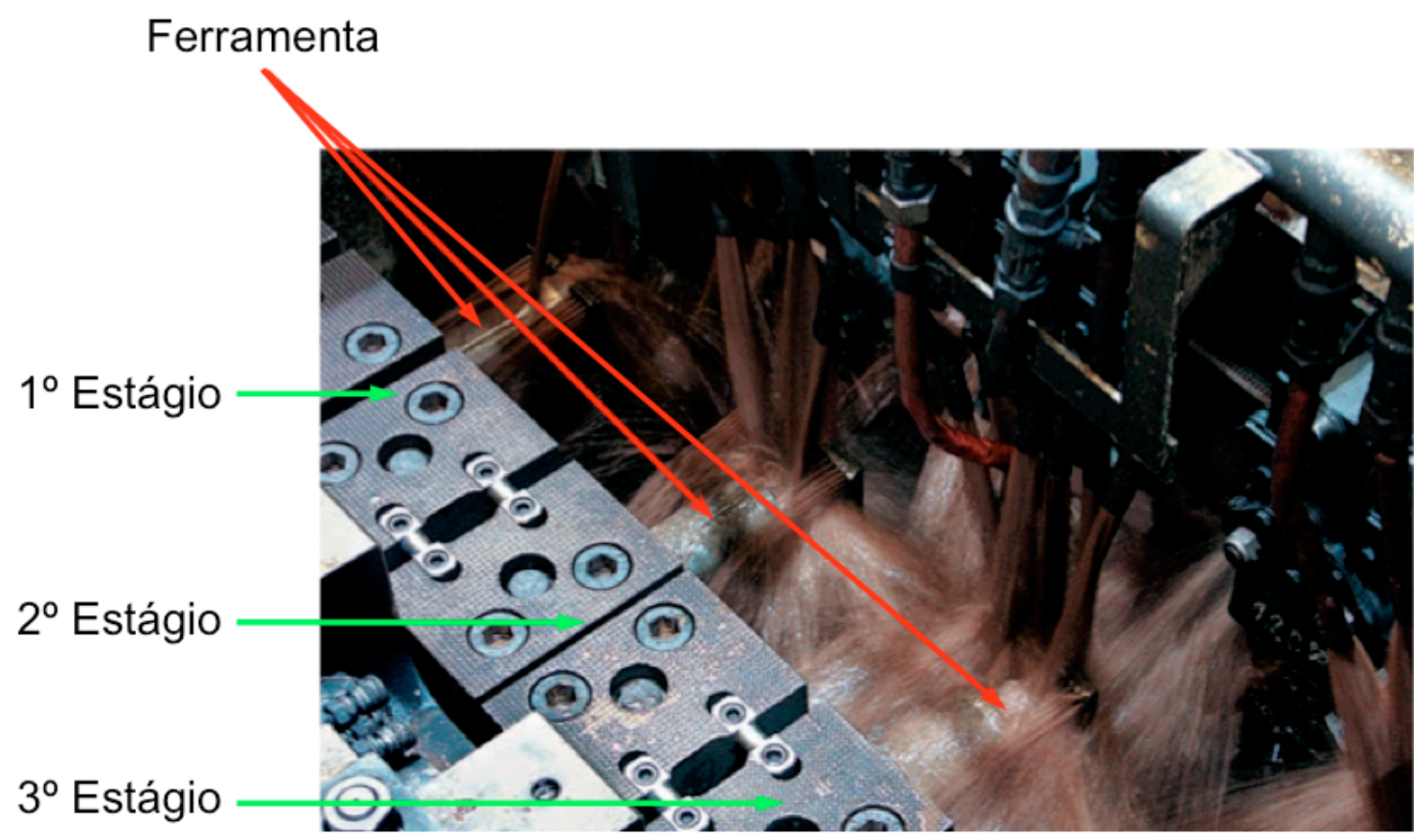

Figura 19 - Refrigeração das ferramentas de forjamento a quente utilizadas na prensa mecânica horizontal de múltiplos estágios modelo Hatebur AMP70 (Adaptado de [8]).

\subsubsection{Tribologia no Forjamento a Quente}

O tribossistema no forjamento a quente é composto por outras variáveis além das gerais definidas pela norma DIN 50320. Dentre elas, as principais são: variáveis de resistência mecânica, variáveis químicas e variáveis térmicas $[6,12,24,30,47]$. As características mecânicas englobam as tensões, os movimentos relativos, as velocidades de deslizamento na superfície das ferramentas, a resistência mecânica da ferramenta e a dureza da ferramenta. Já as características químicas resumem inúmeras variáveis como composição química das superfícies em contato, composição química do meio interfacial e afinidade química entre os elementos do tribossistema. As características térmicas estão relacionadas à faixa de temperatura à qual o tribossistema é submetido, também exercendo influência nas demais características $[5,8,31,40,48,50]$. 
RAHN et SCHRUFF [24] afirmaram que além das variáveis físicas, químicas e tribológicas, as ferramentas ficam suscetíveis a fatores ligados à máquina, ao método, aos operadores e aos materiais.

A Figura 20, proposta por LANGE [6], evidencia a formação típica de um tribossistema do forjamento a quente, com destaque para a interface formada entre a ferramenta e o blank, onde estão destacadas esquematicamente a microestrutura do aço ferramenta, o meio interfacial com as camadas de óxidos e de lubrificante e o material do blank que será forjado. Alguns dos óxidos formados possuem dureza superior à da ferramenta, sendo potenciais partículas abrasivas, e outros óxidos possuem dureza inferior à da ferramenta, podendo agir como lubrificantes sólidos durante o forjamento $[6,31,49,50]$.

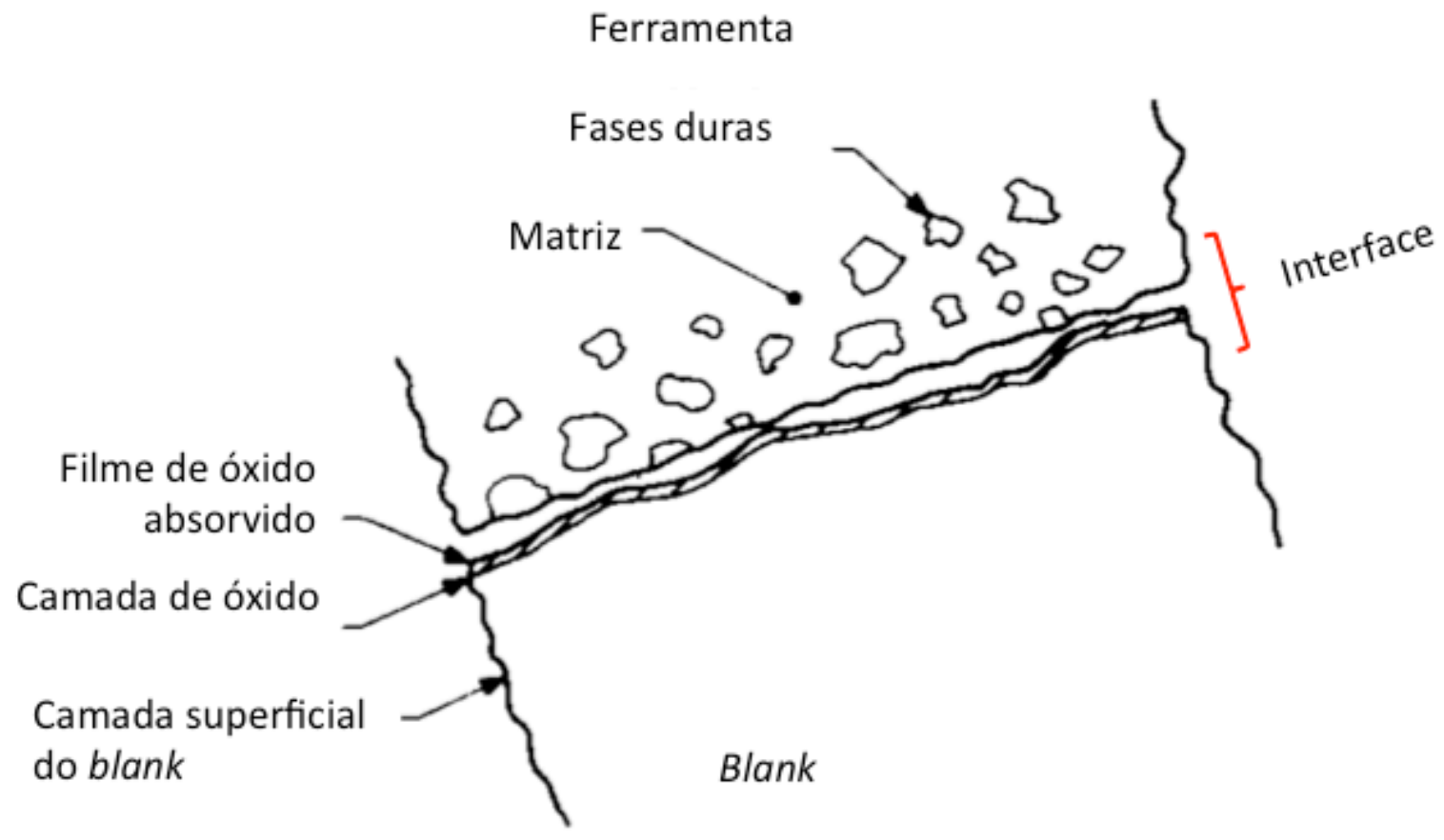

Figura 20 - Tribossistema típico do forjamento a quente (Adaptado de [6]).

No caso de aços, os óxidos formados são predominantemente óxidos de ferro. Esta formação é iniciada naturalmente a partir do momento em que o aço é exposto à atmosfera quando o oxigênio reage com o ferro e é potencializada com o aumento da temperatura e o tempo de exposição. A partir de $200^{\circ} \mathrm{C}$ observa-se com mais intensidade a oxidação, porém a partir de $850^{\circ} \mathrm{C}$ a oxidação é maior $[6,10]$. Os óxidos de ferro formados podem assumir comportamento lubrificante ou abrasivo, 
dependendo da dureza que possuem e em relação à dureza do contra-corpo. Os óxidos com comportamento lubrificante são wustita e magnetita, os quais são diferentes da hematita, que assume o comportamento de partícula abrasiva entre a superfície da ferramenta e o blank $[51,52,49]$. Na Tabela 6 estão descritos os óxidos de ferro formados e as respectivas durezas de cada um deles, medidas na temperatura ambiente. Em (a), os valores de referência mencionados por BARRAU et al. [49], em dureza Vickers e em (b) as durezas dos óxidos de ferro, medidos por nanoindentação e expostos em GPa, evidenciados por TAKEDA et al. [51] e ROZENKRANZ et al. [52].

Tabela 6 - Durezas dos óxidos de ferro medidos à temperatura ambiente (Adaptado de [49,51,52]).

\begin{tabular}{|l|c|c|}
\hline \multicolumn{1}{|c|}{ Óxido de ferro } & (a) Dureza (HV) & (b) Dureza (GPa) \\
\hline Wustita $(\mathrm{FeO})$ & $270-300$ & 3,5 \\
\hline Magnetita $\left(\mathrm{Fe}_{3} \mathrm{O}_{4}\right)$ & $420-500$ & 4,0 \\
\hline Hematita $\left(\mathrm{Fe}_{2} \mathrm{O}_{3}\right)$ & 1030 & 6,7 \\
\hline
\end{tabular}

Além da temperatura e do tempo de exposição, a oxidação é influenciada pelo método de aquecimento do blank que é utilizado no forjamento e, segundo ABACHI [10] existe uma quantia aceitável para cada método de aquecimento para que a formação de óxidos não implique na qualidade do produto forjado, conforme mostrado na Tabela 7

Tabela 7 - Quantidade de oxidação aceitável conforme o forno utilizado para aquecer o blank [10]

\begin{tabular}{|l|c|}
\hline \multicolumn{1}{|c|}{ Tipo de forno } & Oxidação aceitável (\%) \\
\hline Óleo & 4,0 \\
\hline Gás & 3,0 \\
\hline Gás - forno contínuo & 2,5 \\
\hline Elétrico & 1,5 \\
\hline Indutivo & 1,0 \\
\hline
\end{tabular}

No entanto, durante o aquecimento do blank é difícil prevenir a formação de óxidos, porém a remoção da camada formada pode resultar em menos desgaste às 
ferramentas e melhores condições superficiais dos produtos forjados. A remoção desta camada de óxido pode ser mecânica, por jatos de ar comprimido ou por meio de jatos de água pressurizados [5].

Uma das maneiras de reduzir os danos às ferramentas, por exemplo, tentando-se diminuir a ação das partículas abrasivas, é pela introdução de um lubrificante na interface $[3,5,6]$. O fluxo de material na gravura das ferramentas é diretamente influenciado pelas condições da interface ferramenta/material podendo, inclusive, determinar o sucesso da operação. Esta interação determina a qualidade superficial do produto forjado, o desempenho das ferramentas, a força necessária para o forjamento entre outros resultados. Segundo ALTAN [3], no forjamento, a lubrificação pode ser dividida em três tipos [3]:

a) Interface sem lubrificação: não há nenhum componente lubrificante na interface ferramenta/material. Apenas as camadas de oxidação, da ferramenta e do material, estão presentes. Neste caso, o atrito é em geral elevado;

b) Interface com lubrificação hidrodinâmica: na interface ferramenta/material existe uma camada espessa de lubrificante. Neste tipo de lubrificação a condição de atrito é determinada pela viscosidade do lubrificante e pela viscosidade relativa entre a ferramenta e o material;

c) Interface com lubrificação limítrofe: condição de lubrificação mais comum nos processos de conformação de metais. A elevação da temperatura e as pressões altas atingidas durante o processo permitem pouca presença de lubrificante na interface.

A lubrificação atua também como um importante mecanismo de retirada de calor, contribuindo para diminuir o desgaste das ferramentas durante o forjamento [5]. 


\subsection{Desgaste de ferramentas}

Desgaste é o volume de material removido de uma superfície devido ao movimento relativo entre duas ou mais superfícies que estão em contato [27,28]. Existem muitos modelos físicos que tentam definir o desgaste, no entanto, nenhum modelo é universal, único e absoluto, podendo ser aplicado para todas as situações de desgaste [26]. SOUZA [19] fez uma síntese dos principais enunciados que definem o desgaste:

a) A perda de material que ocorre em uma superfície quando ela rola, desliza ou colide contra outra superfície;

b) Mudanças indesejadas e acumulativas em dimensões, pela remoção gradual de partículas devido ao contato entre as superfícies em movimento relativo;

c) O dano progressivo, associado à perda de material que ocorre sobre a superfície de um componente, resultado do movimento relativo a um contra-corpo.

Em resumo, o desgaste encontrado nas ferramentas é o dano progressivo e irreversível em superfícies, que resulta na perda das características originais da geometria, da topografia e das dimensões, comprometendo o desempenho da ferramenta durante o processo de forjamento $[6,9,27,28]$.

SOUZA [19], utilizando a imagem apresentada na Figura 21, mostrou a ação do desgaste em diferentes tipos de superfície encontradas em situações do dia a dia, onde o par tribológico é distinto e bastante variado. 


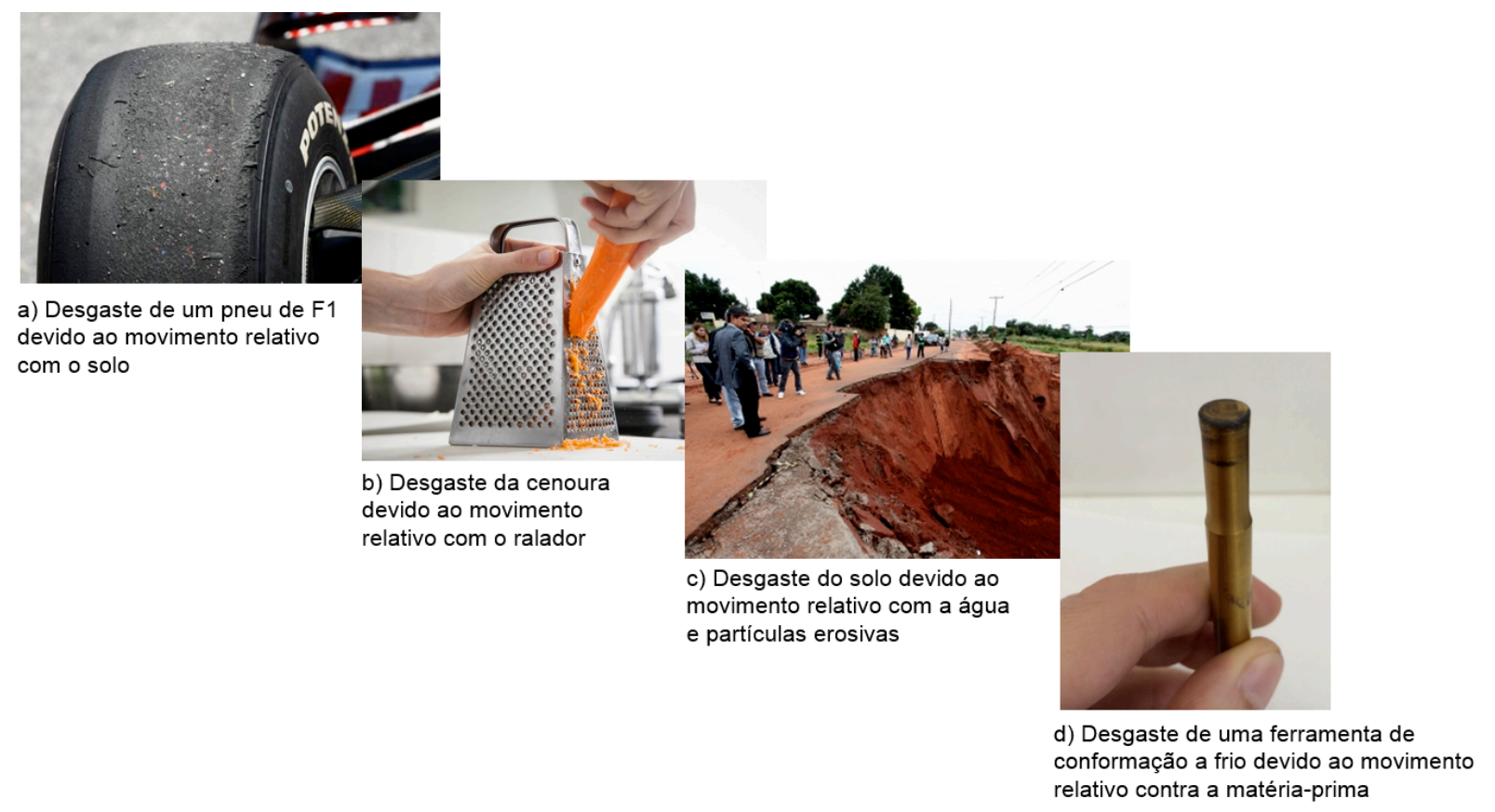

Figura 21 - Exemplos de diferentes superfícies desgastadas [19].

Diversas variáveis influenciam diretamente a durabilidade das ferramentas, desde o projeto até a utilização correta do ferramental. Muitos autores conduziram estudos e pesquisas para determinar as influências das variáveis na vida útil das ferramentas, conforme ilustração da Figura 22 [5,6,10,12,47,53]. 


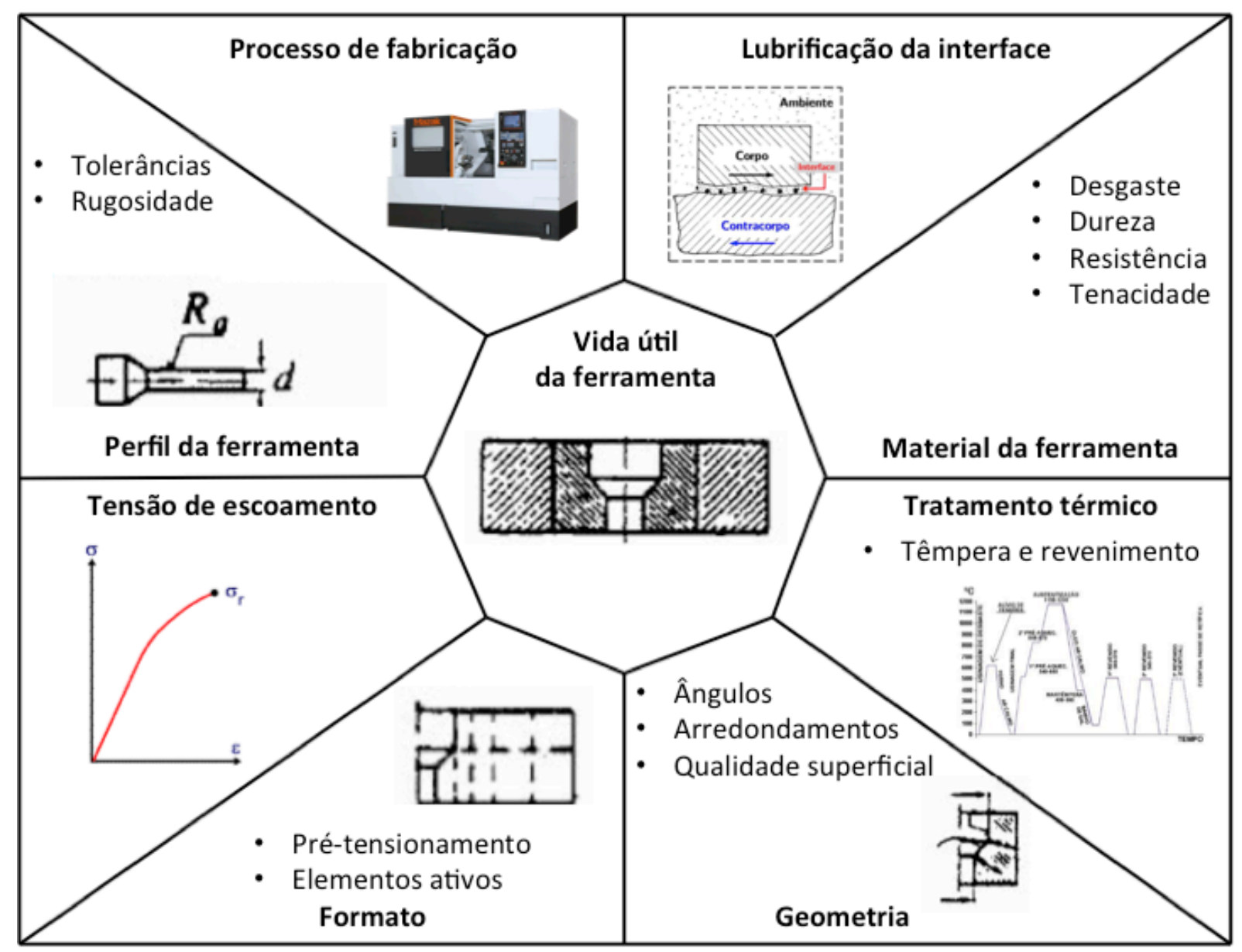

Figura 22 - Variáveis que influenciam o desempenho das ferramentas (Adaptado de [47]).

Diversos autores mostram que o principal modo de falha do ferramental de forjamento a quente é o desgaste, superando aspectos como deformação plástica, fadiga mecânica e fadiga térmica $[9,12,47,53,54]$. Após diversos estudos e trabalhos de investigação do desgaste no forjamento a quente, vários autores corroboram que regiões distintas da mesma ferramenta podem apresentar desgaste diferente [9,26,30,47,53-55]. A Figura 23 mostra o levantamento feito para os principais modos de falha observados no forjamento a morno, nos quais o desgaste das ferramentas representa $70 \%$ das ocorrências $[9,47,55]$. 


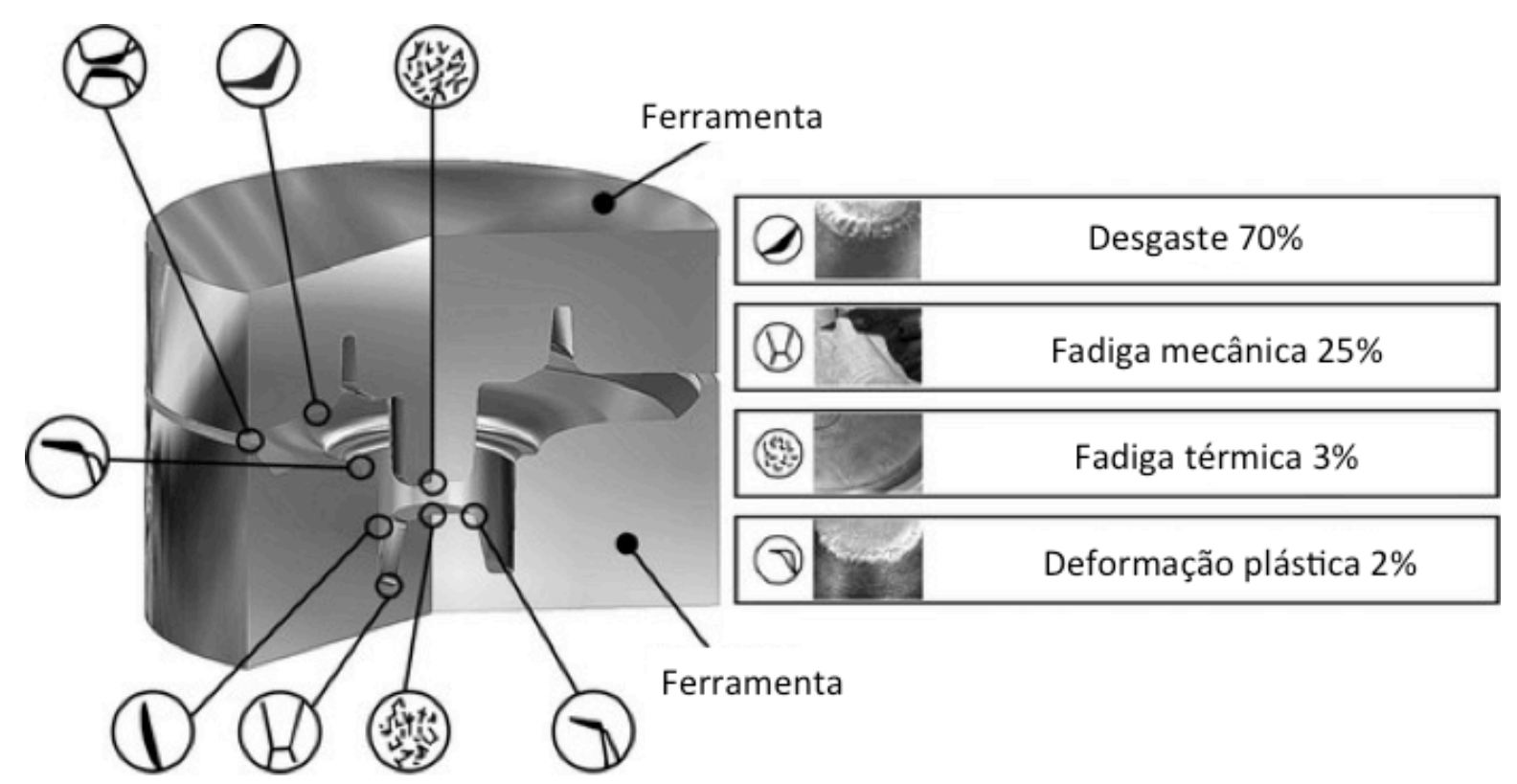

Figura 23 - Desgaste em ferramentas de forjamento a quente (Adaptado de [55]).

Os estudos de SUMMERVILLE et al. [9], mostraram o desgaste como a maior fonte de danos às ferramentas utilizadas na conformação a morno. Logo, pela proximidade de temperaturas, cria-se uma expectativa natural de frequência de falhas por desgaste próxima ou até superior nos processos de forjamento a quente.

Estudos mais recentes apontam para resultados diferentes de desgaste. BERGSTRÖM et al. [56] concluíram que a fadiga térmica é a maior fonte de danos às ferramentas contrapondo-se à opinião de outros autores $[9,49]$. Tal afirmação vai na direção da observação de que a alteração dos mecanismos de desgaste influencia na intensidade do desgaste observado [27,57]. Usando um teste de forjamento a quente, SINGH et al [40] mostraram a influência da temperatura no desgaste de ferramentas e apontaram a fadiga térmica como umas das causas do desgaste em ferramentas de forjamento. Por consequência, foi sugerido o estudo da oxidação do aço nas condições de trabalho, uma vez que as altas temperaturas favorecem a oxidação do aço ferramenta e do material que será forjado [6,30,40].

HUTCHINGS [27], mostrou a influência dos mecanismos responsáveis pela degradação da superfície e a intensidade de desgaste. O resultado de um ensaio pino-disco, ao longo do qual um pino de aço médio carbono é submetido a uma velocidade de deslocamento de $1 \mathrm{~m} / \mathrm{s}^{2}$, em relação a um disco de aço-ferramenta, 
mostrou a transição da intensidade do desgaste com a variação da carga. No estudo, em baixas cargas observou-se a formação de uma camada de óxido no pino, alojando-se na interface entre o pino e o disco e mantendo o desgaste moderado. A medida que a carga foi aumentada, a camada de óxido danificou-se, gerando debris e uma repentina alteração no regime de desgaste ocorreu [27].

Como sugerido acima, a alteração na intensidade do desgaste motivou a classificação do desgaste em dois grupos: em desgaste moderado e desgaste severo. Feito por observação e sem nenhum modelo matemático definido, são classificações que levam em consideração a pressão normal, velocidade de deslizamento e a temperatura do tribossistema, resultando numa mudança de aspecto superficial bem definida $[10,26]$. A comparação entre desgaste moderado e desgaste severo pode ser feita usando-se a Tabela 8, onde estão descritas as principais características destas duas classificações.

Tabela 8 - Classificação do desgaste: (a) moderado; (b) severo (Adaptado de [10])

\begin{tabular}{|l|l|}
\hline \multicolumn{1}{|c|}{ (a) Desgaste moderado } & \multicolumn{1}{|c|}{ (b) Desgaste severo } \\
\hline Superfície lisa, baixa rugosidade & Superfície muito desgastada, elevada rugosidade \\
\hline Superfícies menos rugosas que a original & Superfícies mais rugosas que as originais \\
\hline $\begin{array}{l}\text { Partículas abrasivas pequenas. Usualmente menores que } \\
100 \text { nm de diâmetro }\end{array}$ & $\begin{array}{l}\text { Partículas abrasivas grandes. Usualmente até } 0,01 \text { mm de } \\
\text { diâmetro }\end{array}$ \\
\hline $\begin{array}{l}\text { Elevada resistência de contato elétrico, baixo contato } \\
\text { metálico }\end{array}$ & Baixa resistência de contato, ligações metálicas \\
\hline
\end{tabular}

A intensidade do desgaste está diretamente ligada aos tipos de desgaste: adesão, abrasão, fadiga mecânica e fadiga térmica. Estes tipos de desgaste são os mais comuns nos processos de forjamento a quente $[6,10,31,54]$.

Para quantificar o desgaste, Holm e Archard propuseram um modelo matemático para equacionar a quantidade de material removido em função da carga normal aplicada e da dureza da superfície desgasta [27,28]. Este modelo ficou conhecido como modelo de Archard, está descrito na equação 1. 
$Q=\frac{K \cdot W}{H}$

Onde:

Q: Desgaste

W: Carga normal aplicada [N]

$\mathrm{H}$ : Dureza da superfície [Pa]

$\mathrm{K}$ : Coeficiente de desgaste

O coeficiente de desgaste " $K$ " foi pesquisado e definido empiricamente em inúmeros trabalhos científicos. Os ensaios para determinar os valores de "K" muitas vezes consistem em um ensaio pino disco, onde os pinos dos materiais que se deseja obter o valor de "K" deslizam, sem lubrificação, contra um disco construído em aço ferramenta que gira $[3,40]$. Os valores que "K" pode assumir variam de acordo com o tribossistema formado. Na Tabela 9, estão descritos alguns dos valores do coeficiente "K", calculados, utilizando-se a equação de Archard para o ensaio pino-disco, sendo disco de aço ferramenta e a interface sem lubrificação [40].

Tabela 9 - Coeficientes de desgaste "K" obtidos em ensaios pino disco (Adaptado de [40]).

\begin{tabular}{|l|r|}
\hline \multicolumn{1}{|c|}{ Material } & \multicolumn{1}{c|}{ K (adimensional) } \\
\hline Aço carbono & $7 \times 10^{-3}$ \\
\hline Latão & $6 \times 10^{-4}$ \\
\hline PTFE & $2,5 \times 10^{-5}$ \\
\hline Cobre-berílio & $3,4 \times 10^{-5}$ \\
\hline Aço ferramenta & $1,3 \times 10^{-4}$ \\
\hline Aço inoxidável ferrítico & $1,7 \times 10^{-5}$ \\
\hline Polietileno & $1,3 \times 10^{-3}$ \\
\hline PMMA & $7 \times 10^{-6}$ \\
\hline
\end{tabular}

A Figura 24 exemplifica o modelo matemático proposto por Holm e Archard para definir o volume de material removido por uma única partícula abrasiva quando descreve movimento relativo em relação ao contra-corpo. Nesta representação, além das variáveis da equação 1, a distância percorrida pela partícula, "I", a 
profundidade penetrada na superfície, "d", e o ângulo da ponta da partícula abrasiva, " $\alpha$ ", combinam-se e são utilizadas na quantificação do material removido da superfície [28,31].

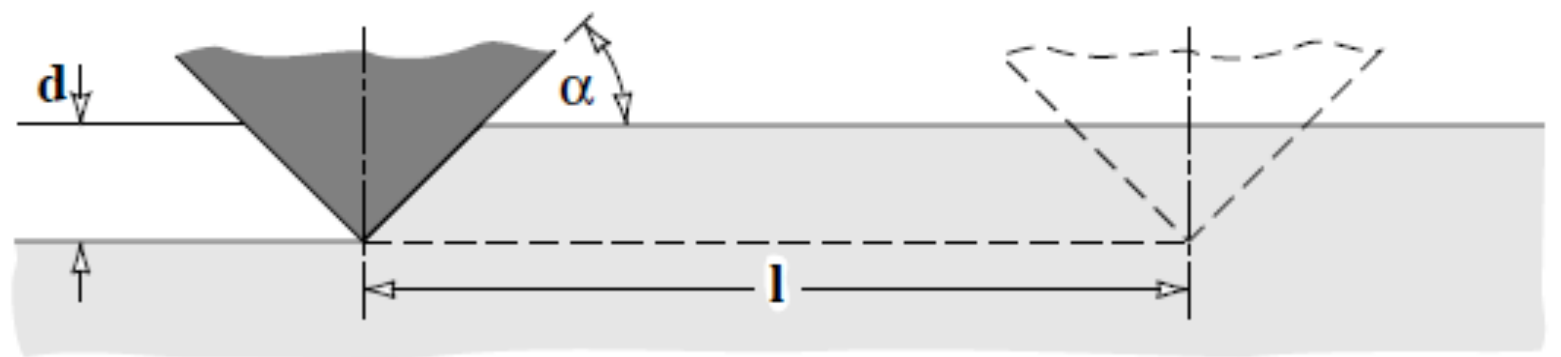

Figura 24 - Modelo representativo da fórmula de Archard para determinar o volume de material removido por uma partícula abrasiva [28].

A correlação entre as variáveis resulta na equação 2, que avalia a carga aplicada à partícula abrasiva:

$W g=0,5 \cdot \pi \cdot(d \cdot \cot \alpha)^{2} \cdot H$

Onde:

$\mathrm{W}_{\mathrm{g}}$ : é a carga aplicada na partícula abrasiva $[\mathrm{N}]$;

d: é a profundidade da impressão causada pela partícula [m];

a: é o ângulo formado entre a superfície e o cone da partícula abrasiva;

H: a dureza da superfície [Pa].

O volume de material removido pela partícula abrasiva é, então, função da distância percorrida "l", da profundidade da impressão e da seção transversal da partícula abrasiva, conforme a equação 3. 
$V g=l \cdot d^{2} \cot \alpha$

Onde:

$\mathrm{V}_{\mathrm{g}}$ : é o volume de material removido pelo cone da partícula abrasiva $\left[\mathrm{m}^{3}\right]$. 


\section{MATERIAIS E MÉTODOS}

Este trabalho foi conduzido nas instalações da empresa Neumayer Tekfor Automotive Brasil Ltda (NTA), em Jundiaí - SP e nas instalações da Escola Politécnica da USP (EPUSP), em São Paulo. A Neumayer Tekfor é uma empresa parceira da indústria automobilística e fornece produtos e soluções inovadoras para diversas aplicações automotivas. A produção das ferramentas e o acompanhamento do forjamento ocorreu entre abril de 2014 e agosto de 2016. No Laboratório de Fenômenos de Superfície (LFS) da EPUSP, foram conduzidos os ensaios de laboratório: preparação de amostras e as análises, de microscopia eletrônica de varredura e nanodureza.

\subsection{Forjamento}

Por meio da avaliação do histórico de informações de produção, vendas e conforme a estratégia da empresa, foi escolhida a porca de roda com arruela integrada como base deste trabalho. Este produto é utilizado na fixação das rodas de veículos comerciais pesados e foras de estrada ${ }^{6}$, como mostra a Figura 25.

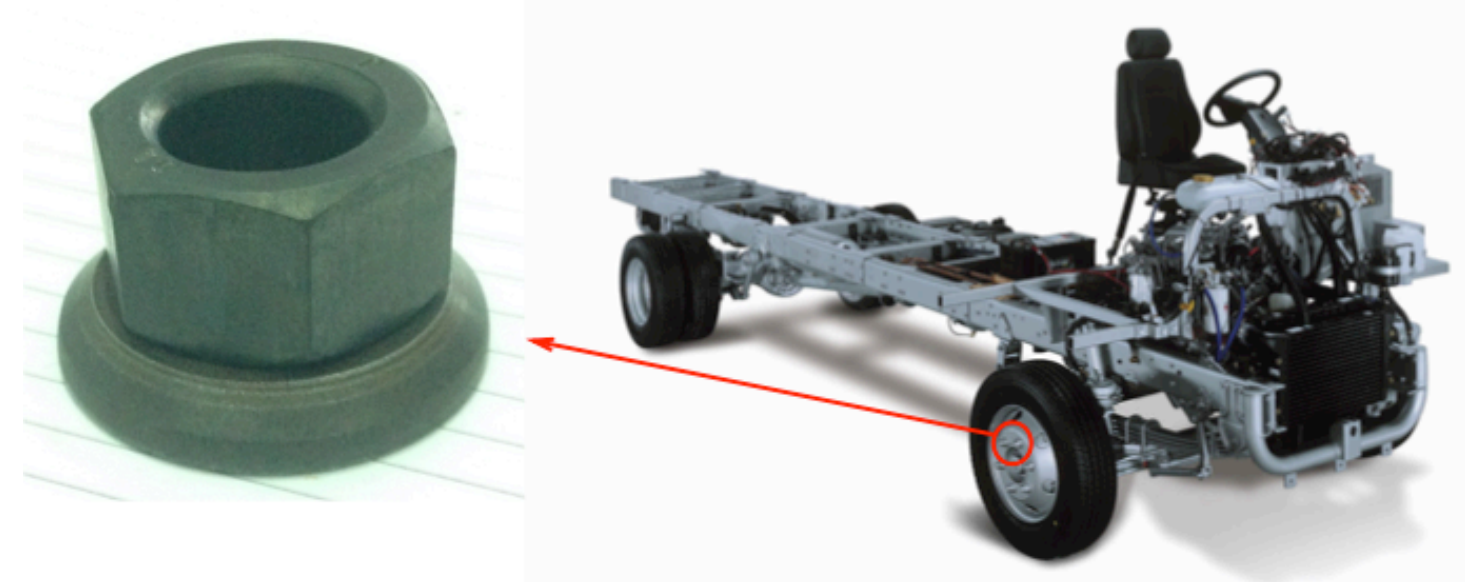

Figura 25 - Porca de roda ${ }^{7}$ para veículos pesados - caminhões e ônibus.

\footnotetext{
${ }^{6}$ Veículos for a de Estrada, do inglês "off-road", são veículos que não circulam por vias urbanas convencionais e são destinados aos trabalhos agrícolas, à mineração e às aplicações militares.

${ }^{7}$ Imagem da porca de roda é uma cortesia da Neumayer Tekfor Automotive Brasil Ltda.
} 
Este produto é forjado em aço SAE 1045, o qual apresenta a composição química da Tabela 10 conforme a norma SAE J403:2001. Devido a especificações de resistência mecânica, a porca passa pelo tratamento térmico de têmpera e revenimento, para atender a especificação de dureza e também às solicitações da aplicação de força tensora e torque de aperto.

Tabela 10 - Composição química do aço SAE1045 utilizado no forjamento [58].

\begin{tabular}{|c|c|c|c|c|c|}
\cline { 2 - 6 } \multicolumn{1}{c|}{} & $\mathbf{C}$ & $\mathbf{M n}$ & $\mathbf{P}$ & $\mathbf{S}$ & $\mathbf{S i}$ \\
\hline Mínimo & 0,43 & 0,6 & 0 & 0 & 0,15 \\
\hline Máximo & 0,5 & 0,9 & 0,03 & 0,05 & 0,35 \\
\hline
\end{tabular}

A porca de roda é um conjunto montado com uma porca e uma arruela. Neste trabalho, o produto forjado escolhido como base foi a porca que está apresentada na Figura 26, na qual é possível observar a sua geometria em duas vistas. Em (a), a porca é mostrada de planta. Em (b), a porca é observada em elevação, onde é possível observar a transição do sextavado para o diâmetro do colar. É no colar que a arruela é montada para formar o conjunto da porca de roda.

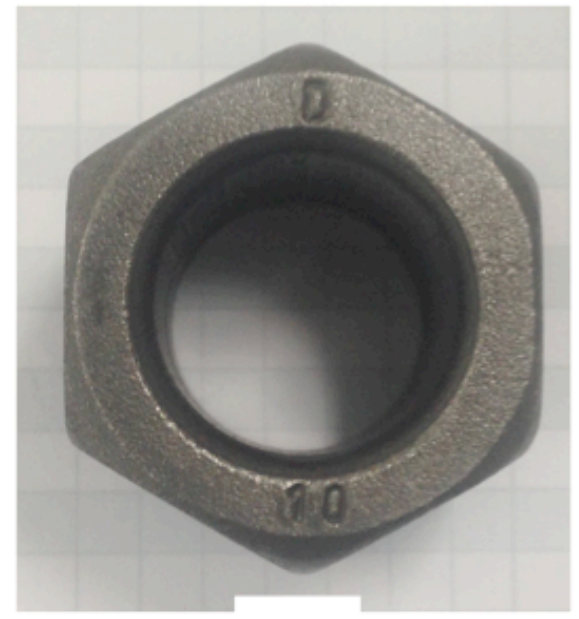

(a)

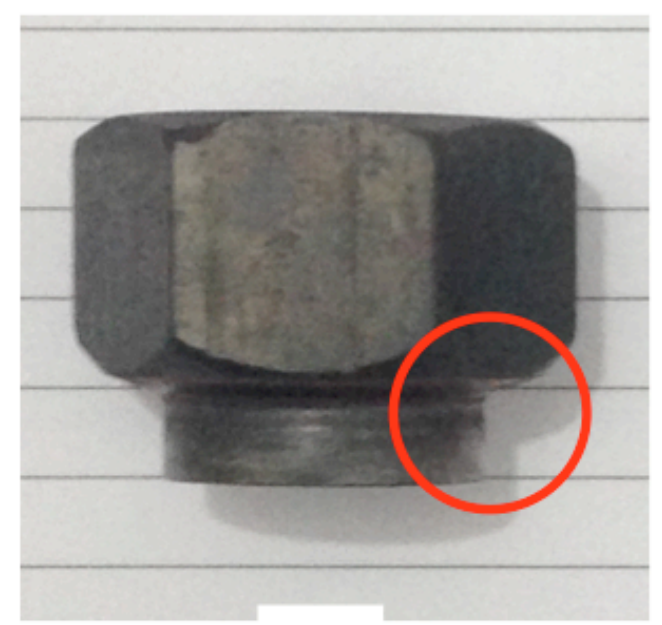

(b)

Figura 26 - Porca forjada em aço SAE 1045. (a) Vista superior; (b) Perfil da porca com destaque para a transição do corpo sextavado para o corpo cilíndrico.

Para ser fabricada, a porca é submetida a uma sequência de operações de forjamento, conforme apresentado na Figura 27. Em (a), verifica-se o material de entrada, o qual é aquecido por indução, cisalhado e alimentado na prensa, automaticamente e sem a intervenção de operadores. Em (b), a operação de 
recalque, a qual é realizada para eliminar a camada de óxidos ${ }^{8}$ da superfícies do blank gerada durante o aquecimento da barra. Em (c), a porca forjada sem o estágio de furação.

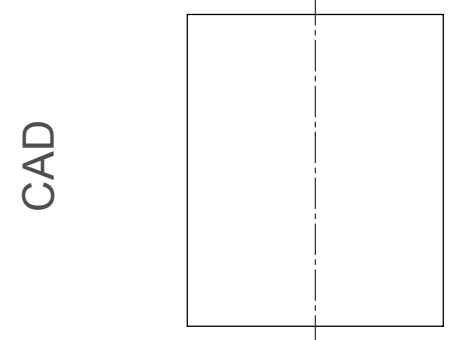

(a)

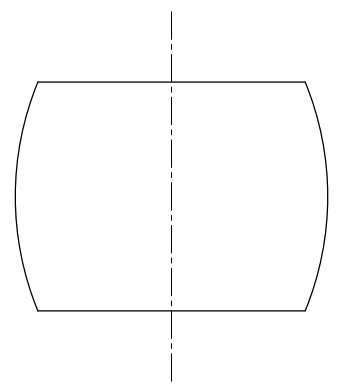

(b)

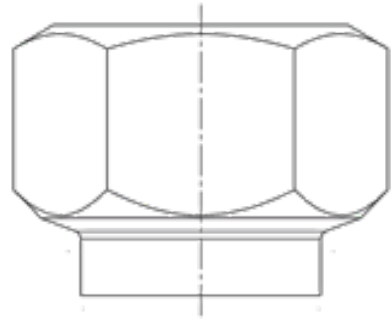

(c)

Figura 27 - Sequência de forjamento da porca de roda: a) blank de aço SAE 1045 cisalhado; b) operação de recalque; c) pré-forma final da porca.

O forjamento desta porca foi feito em uma prensa mecânica automática, modelo Hatebur® AMP $-20^{9}$, de acionamento excêntrico horizontal e com múltiplos estágios $^{10}$. Dependendo das características geométricas do produto e da massa, esta prensa é capaz de produzir até 6000 peças por hora de produção [13]. Neste forjamento foi utilizada a velocidade correspondente a uma produção de 4500 peças por hora. Nesta cadência de forjamento, a taxa de deformação é aproximadamente $90 \mathrm{~s}^{-1}[8,13]$. A Figura 28 apresenta uma visão geral da prensa.

\footnotetext{
${ }^{8} \mathrm{~A}$ formação de óxidos no blank é inerente ao processo de forjamento a quente e é potencializado à medida que a temperatura de forjamento é elevada. No ambiente fabril, a oxidação formada durante o aquecimento é conhecida como "carepa".

${ }^{9}$ Hatebur® AMP-20 é uma prensa mecânica excêntrica horizontal de múltiplos estágios utilizada no forjamento a quente de diversos produtos. É um equipamento dedicado a produção seriada de produtos, na sua grande maioria, para a indústria automobilística.

${ }^{10}$ Múltiplos estágios significa que a prensa possui várias estações de forjamento e, em um mesmo golpe do martelo, realiza todas as operações ao mesmo tempo.
} 


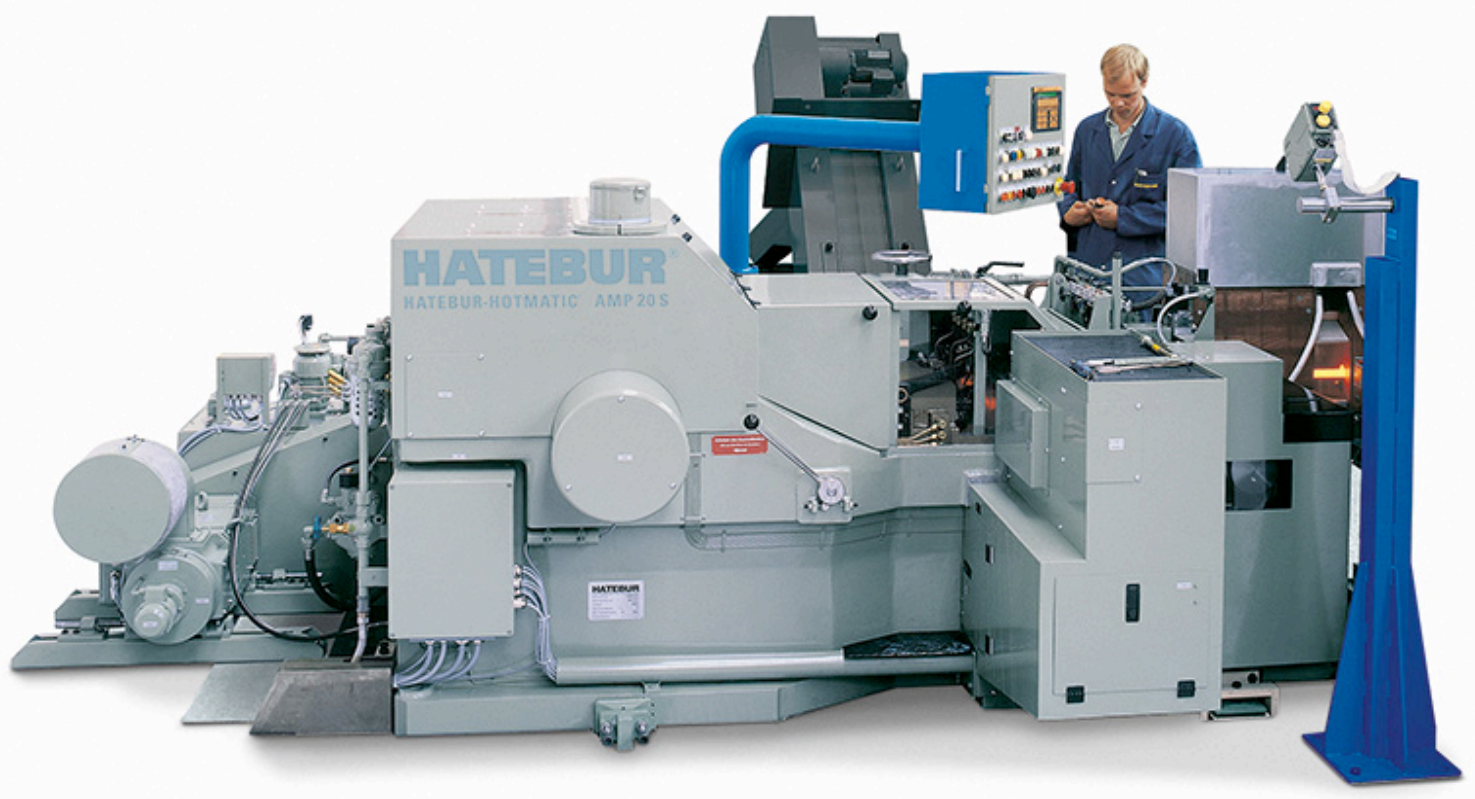

Figura 28 - Visão geral da prensa Hatebur® AMP20 [13].

A Figura 29 apresenta o interior da prensa, onde é possível observar o mecanismo de acionamento e, em destaque, a área de forjamento. Nesta área estão os punções e as matrizes que são utilizadas para forjar a quente os produtos.

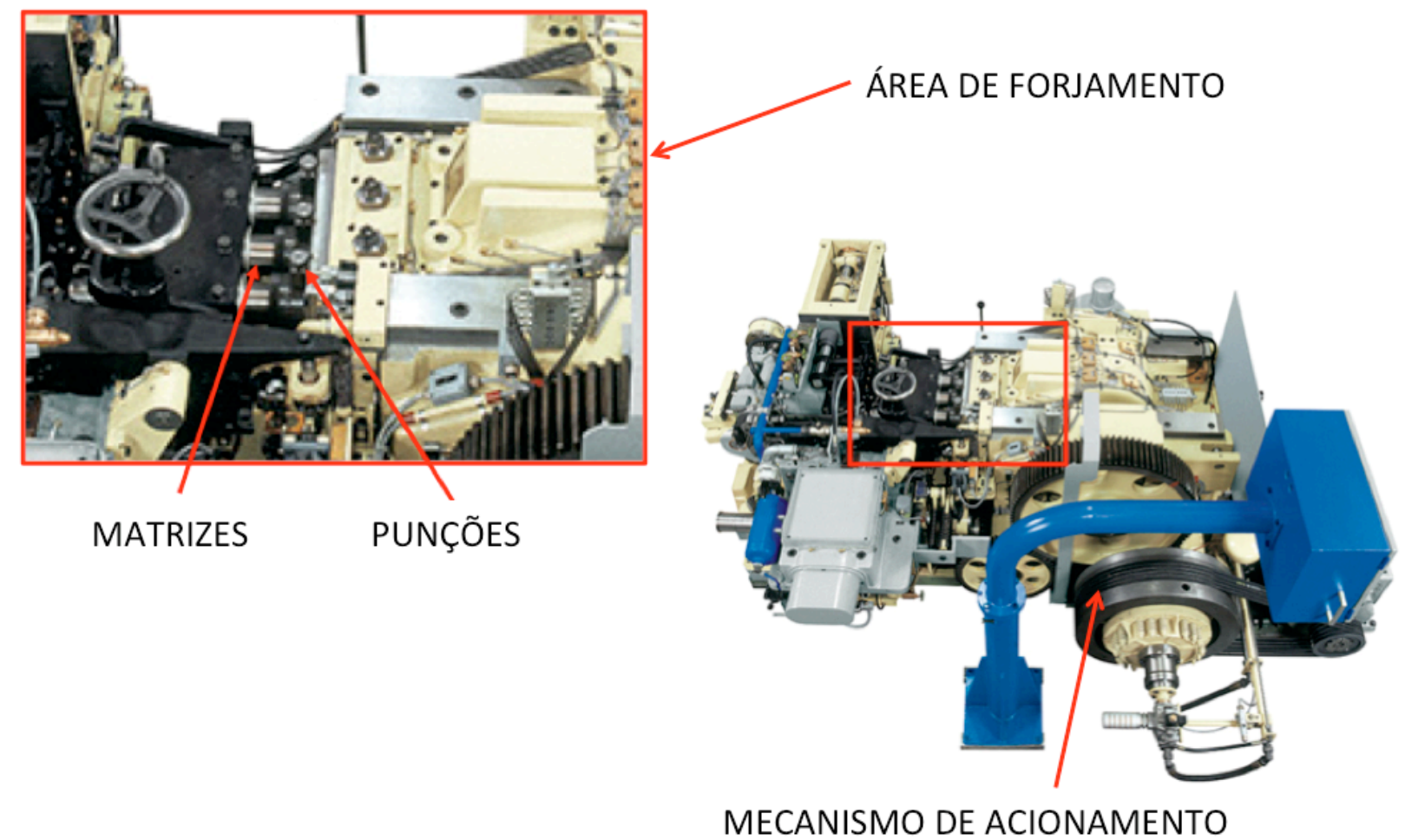

Figura 29 - Detalhes da prensa Hatebur® AMP20.(Adaptado de [13]). 


\subsection{Ferramenta - Punção de Pré-furação}

A ferramenta utilizada no desenvolvimento deste estudo recebe o nome de punção de pré-furação. Esta ferramenta é responsável por preparar a geometria interna da porca para que na operação seguinte ela seja furada. No conjunto de ferramentas, o punção de pré-furação é inserido em um punção maior, o qual é responsável por garantir o preenchimento total da cavidade da matriz e conferir à porca a altura especificada. Utilizando a sequência de fabricação apresentada na Figura 30, foram construídos seis punções de pré-furação, sendo cinco para serem utilizados no forjamento e um como corpo de prova de referência.

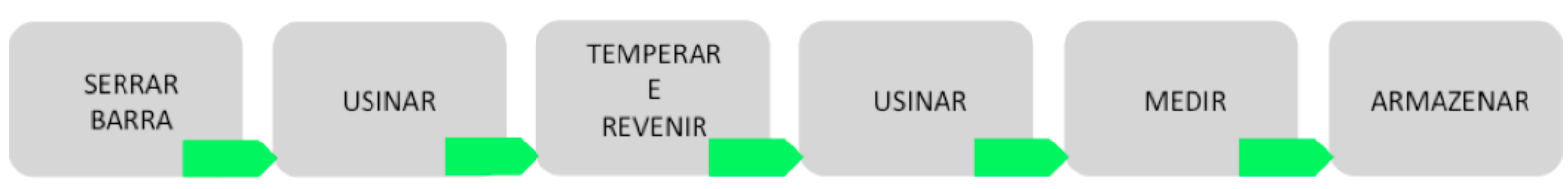

Figura 30 - Fluxograma de fabricação do punção de pré-furação.

Os punções foram fabricados a partir de barras de aço ferramenta $\mathrm{H}-10$ com diâmetro $25,4 \mathrm{~mm}$, o qual possui composição química, em porcentagem de massa, conforme a Tabela $11[20]$.

Tabela 11 - Composição química do aço da H-10 utilizado nos punções [20].

\begin{tabular}{|c|c|c|c|c|c|c|c|c|}
\hline Aço & $\mathbf{C}$ & $\mathbf{M n}$ & $\mathbf{S i}$ & $\mathbf{C r}$ & $\mathbf{M o}$ & $\mathbf{N i}$ & $\mathbf{V}$ & $\mathbf{W}$ \\
\hline $\mathrm{H}-10$ & 0,4 & 0,4 & 1 & 3,3 & 2,5 & - & 0,5 & - \\
\hline
\end{tabular}

Para evitar variações abruptas na composição química do aço ferramenta, uma mesma barra foi utilizada para obter-se os tarugos que seriam usinados. A usinagem foi realizada para obter-se dimensões próximas das medidas finais, deixando apenas sobremetal para a usinagem de acabamento. Foi utilizado o mesmo programa de comando numérico computadorizado - $\mathrm{CNC}^{11}$ para usinar todas as ferramentas.

\footnotetext{
${ }^{11}$ Comando Numérico Computadorizado - CNC são linhas de programação que após serem alimentadas em um software de máquina de usinagem são reproduzidas pelo microprocessador das máquinas-ferramenta possibilitando a repetição da estratégia e dos parâmetros de usinagem escolhidos.
} 
Em seguida realizou-se o tratamento térmico de têmpera e revenimento para obter-se a dureza desejada. Nesta etapa, todos os punções foram conduzidos simultaneamente ao tratamento térmico para evitar variações na microestrutura, visando resultados de dureza semelhantes. A microestrutura desejada é $100 \%$ martensítica com dureza entre 512-545 HV, cerca de 50-52 HRC.

Após o tratamento térmico, os punções foram levados para o segundo processo de usinagem. Nesta segunda etapa, usinaram-se os punções para eliminar as distorções causadas no tratamento térmico e para obter o acabamento superficial desejado. Após a fabricação dos punções, mediram-se as dimensões que sofreriam alteração ao longo dos ciclos de forjamento. Além disso, realizaram-se as medições das massas dos punções antes e depois do forjamento. Para obter estas informações foi utilizado o perfilômetro de contato Mahr com ponta de raio 2,5 mm e uma balança digital Toledo com precisão de 0,1 g. A Figura 31 mostra: Em (a) o punção após o tratamento térmico, e em (b), o desenho 2D com as cotas dimensionadas e controladas, antes e após o forjamento. 


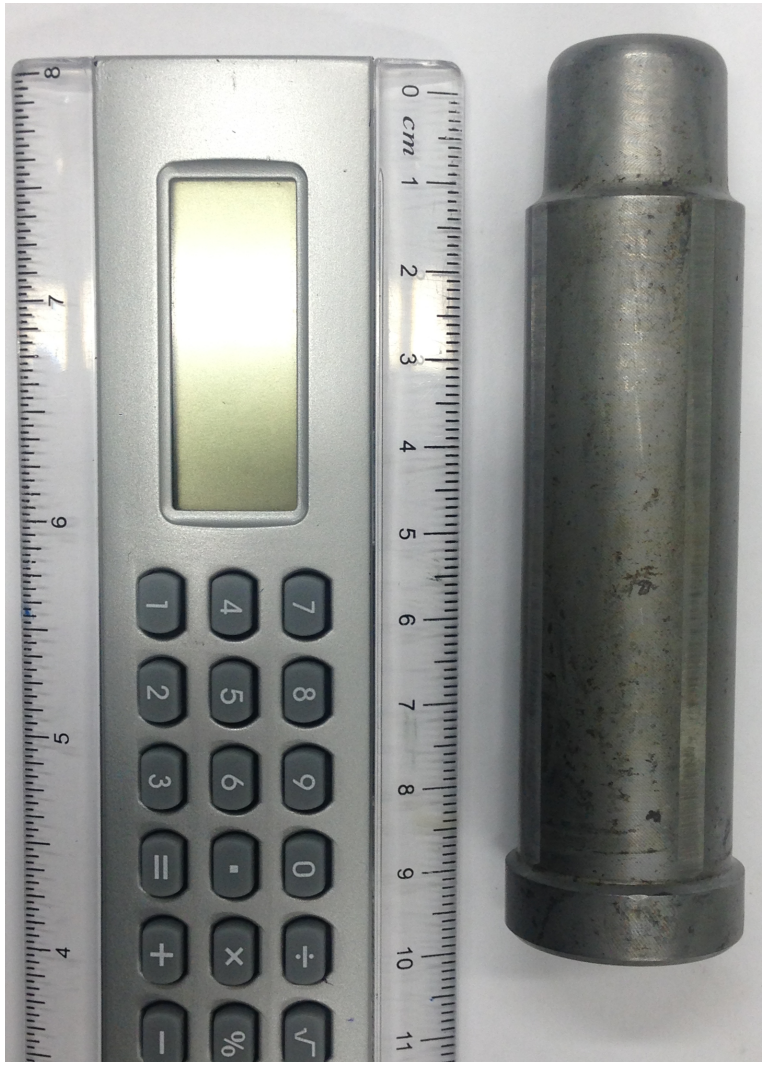

(a)

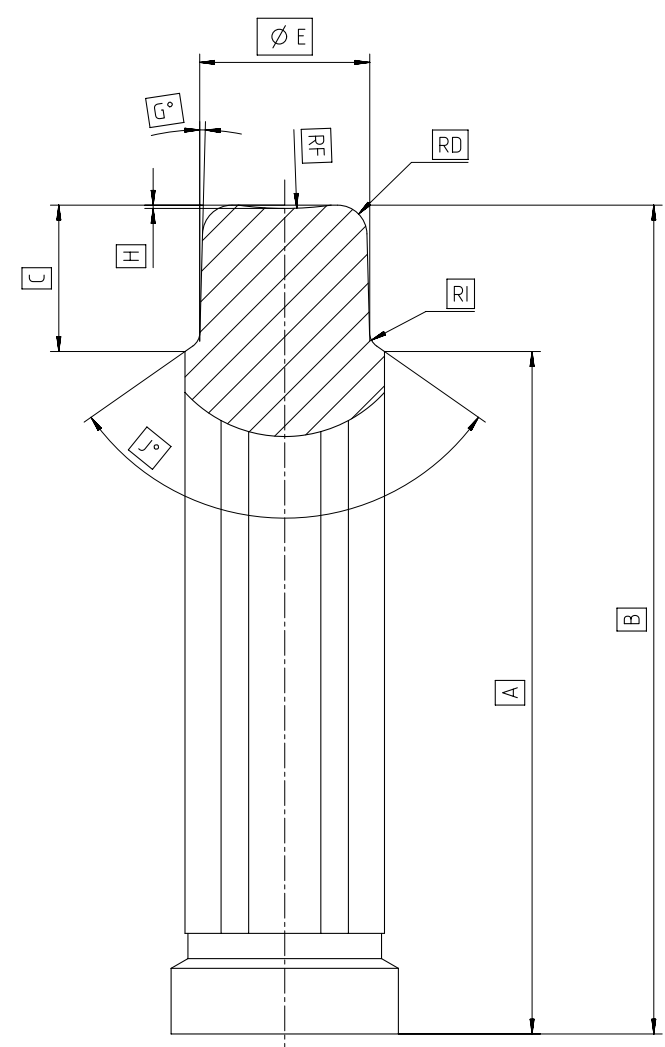

(b)

Figura 31 - Punção PCP: (a) antes da medição; (b) desenho com cotas para serem dimensionadas ${ }^{12}$.

\subsection{Medição da rugosidade}

Com o objetivo de verificar e avaliar a alteração da rugosidade na superfície de contato dos punções, foi estabelecida a medição em parâmetro Ra e Rz de todos os punções, antes e após o forjamento.

Para medir a rugosidade da superfície dos punções, utilizou-se um rugosímetro linear de contato Mitutoyo SJ-310. As medições foram realizadas em quatro pontos diferentes das pontas dos punções, distantes $45^{\circ}$. O comprimento de aquisição da rugosidade utilizado foi de $5 \mathrm{~mm}$, conforme apresentado na Figura 32.

\footnotetext{
${ }^{12}$ As imagens CAD e a ferramenta são cortesia da Neumayer Tekfor Automotive Brasil Ltda.
} 

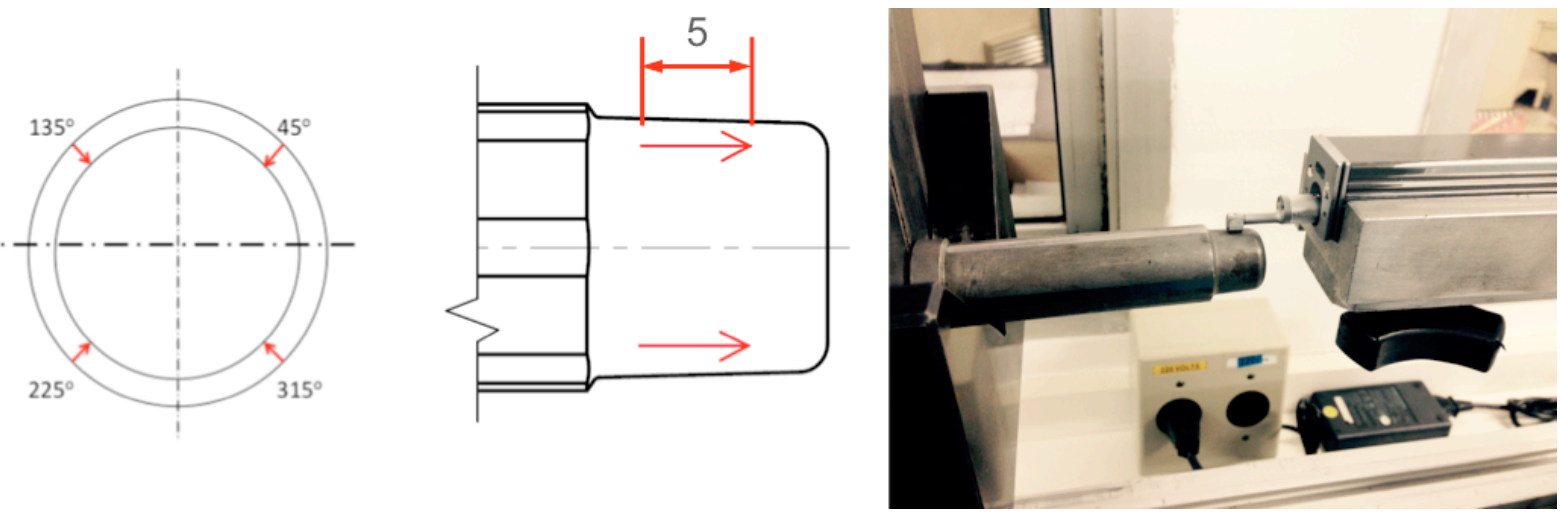

Figura 32 - Medição da rugosidade na ponta dos punções.

\subsection{Estratégia de Forjamento}

De acordo com o histórico de dados e as informações dos operadores da prensa, as ferramentas utilizadas em operações similares a do punção de préfuração têm sua vida útil estipulada em cerca de 10.000 peças. Com base nesta informação, a evolução do desgaste foi estudada para punções com 100, 500, 1000, 2000 e 10000 ciclos de forjamento. A Figura 33 mostra a imagem das ferramentas e a designação utilizada para identificar os cinco punções utilizados no forjamento.

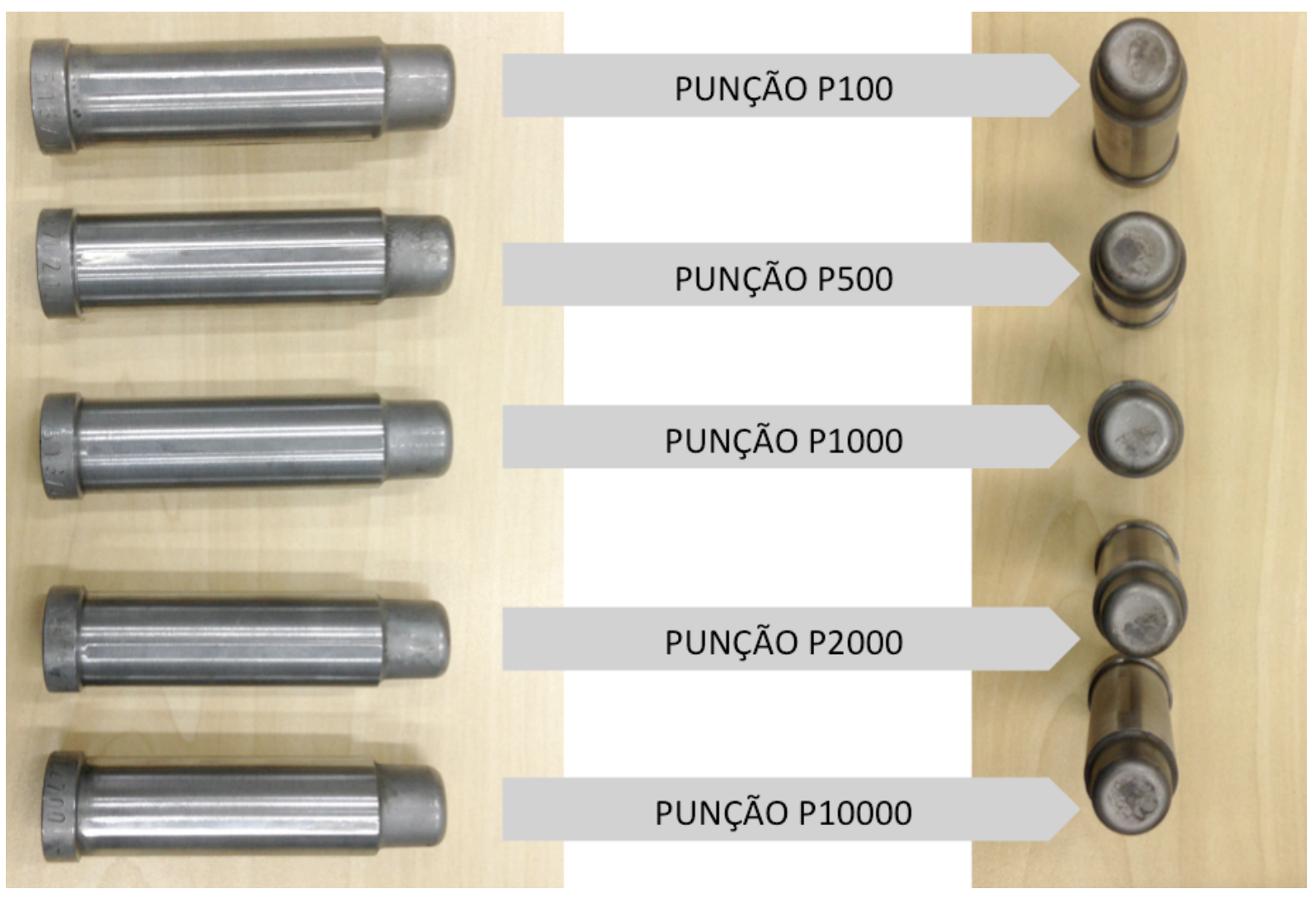

Figura 33 - Punções de pré-furação utilizados no forjamento. 
O sexto punção foi utilizado como corpo de prova de referência, para obterse as informações inicias de dureza, microestrutura, rugosidade e seção transversal. Os resultados obtidos para o sexto punção foram adotados como condição inicial para os demais punções. Este procedimento foi escolhido porque deveriam ser realizadas análises destrutivas nos punções usados no forjamento. O punção utilizado como corpo de prova será nomeado daqui para frente como PCP.

Após o forjamento da respectiva quantidade de peças com cada punção, a sequência de forjamento foi separada para ser analisada posteriormente. A sequência de forjamento consiste nas operações de preparação para obtenção do produto forjado. No caso da porca de roda são três etapas, conforme apresentado na Figura 27, sendo elas: blank cisalhado, recalque e pré-forma. A sequência foi nomeada com as inicias da palavra porca, Po, seguido da respectiva quantidade de peças forjadas.

\subsection{Preparação das Amostras para Análises}

As ferramentas utilizadas neste trabalho foram preparadas e analisadas no LFS. Foram feitos dois tipos de preparação:

a) Preparação das amostras dos punções para que a superfície das pontas do punções fossem analisadas;

b) Preparação das amostras dos punções para que a seção transversal das pontas dos punções fossem analisadas.

A preparação das amostras para análise da superfície foi conduzida de maneira mais simples, porém sem que houvesse prejuízo à região que seria analisada. Foi feito o corte, a limpeza e as análises necessárias no LFS. 
As amostras para análise das seções transversais foram submetidas à uma preparação mais longa. A preparação consistiu em cortar os punções, embutir as seções transversais, lixar, polir, atacar com nital e, por último, limpar.

\subsubsection{Corte}

O corte dos punções foi necessário por não ser possível posicionar o punção na câmara de análise do microscópio eletrônico de varredura (MEV) devido à limitação de espaço. Todos os 6 punções (PCP, P100, P500, P1000, P2000 e P10000) foram cortados na serra circular Struers Discotom do LFS mostrada na Figura 34.

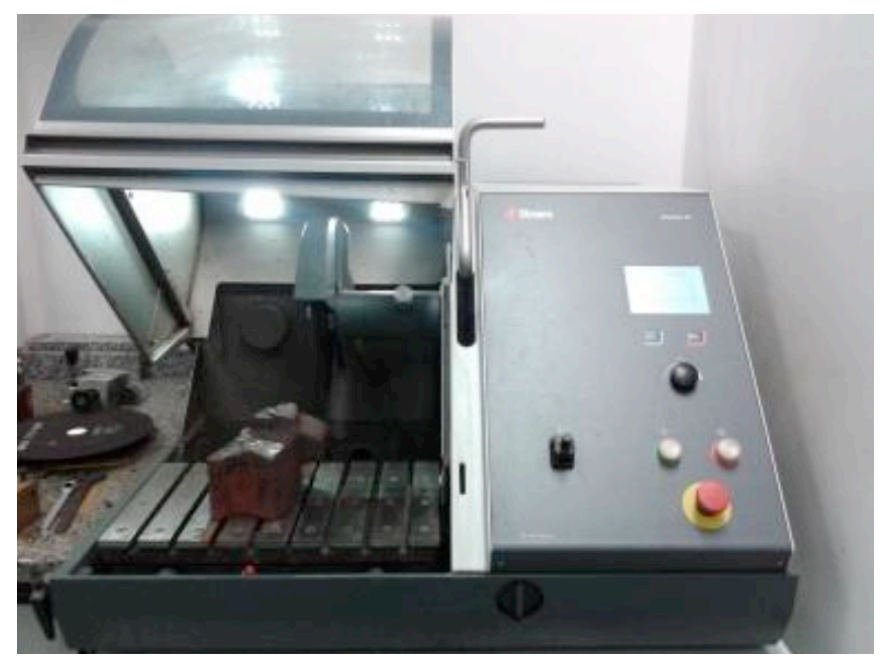

Figura 34 - Serra circular Struers Discotom automática do LFS utilizada no corte dos punções.

O corte na serra circular foi realizado com um disco de corte de $300 \mathrm{~mm}$ de diâmetro e com 3.100 rpm de rotação. O corte foi conduzido em duas etapas, conforme indicado na Figura 35. Em (a), a primeira seção foi realizada para obter-se as pontas dos punções em dimensões que coubessem na câmara do MEV. Em (b), a segunda seção foi realizada na ponta de maneira longitudinal obtendo-se duas metades da ponta dos punções, o que possibilitou a análise da seção transversal. 

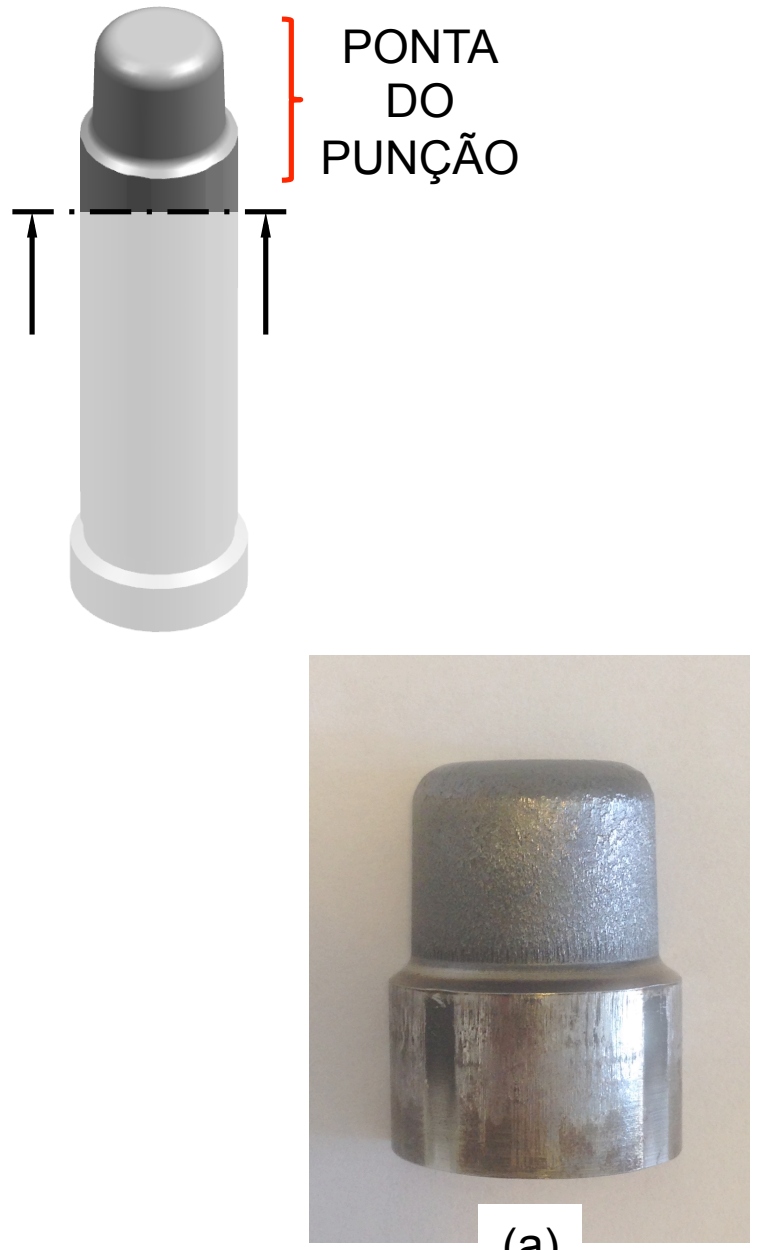

(a)
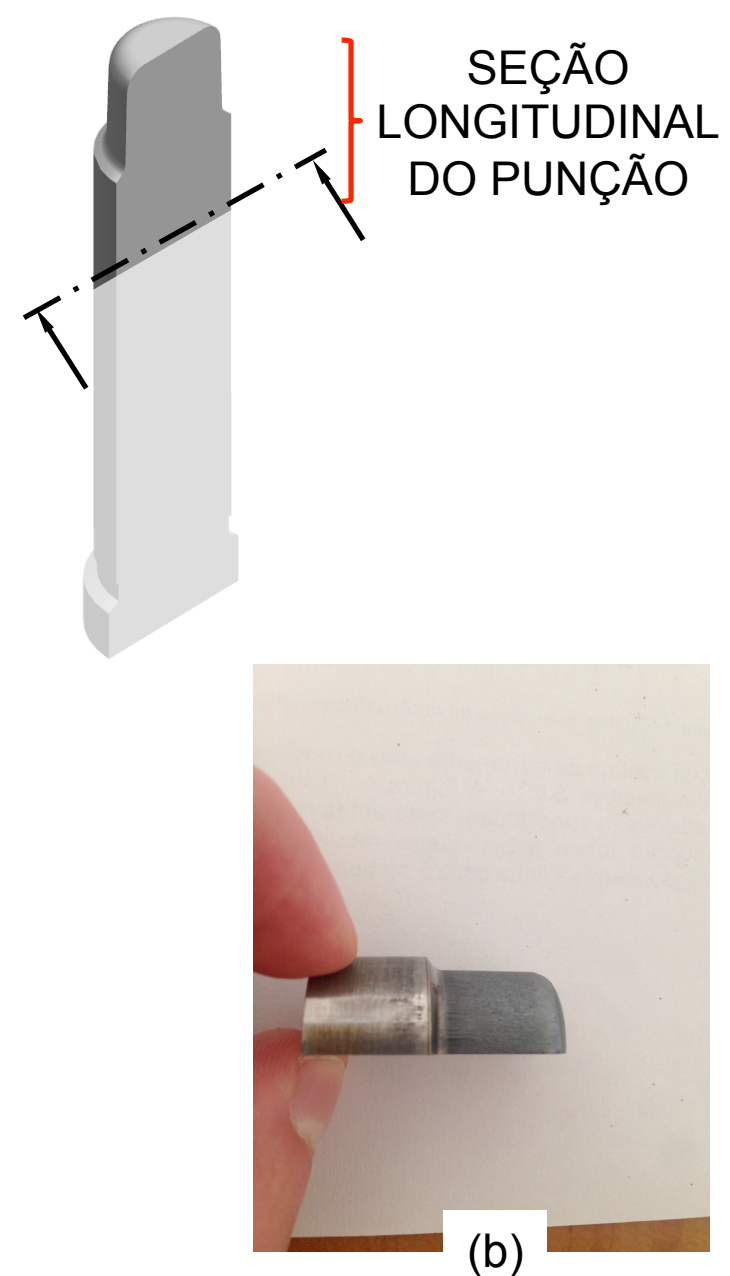

(b)

Figura 35 - Corte dos punções: (a) corte da ponta do punção; (b) corte da seção longitudinal.

Durante o segundo corte, foi utilizado um fluído refrigerante para evitar o aquecimento da região que seria analisada.

Semelhante aos punções, as sequências de forjamento correspondentes aos respectivos punções, foram cortadas exatamente ao meio. Desta forma, foram obtidas seções transversais que pudessem ser analisadas no microscópio para verificar a presença ou não de óxidos nas regiões de contato com as ferramentas.

\subsubsection{Limpeza}

Todos os punções foram limpos para eliminar qualquer resíduo oleoso ou sólido que pudesse estar na superfície dos punções e das sequências de forjamento. As amostras foram posicionadas em um Becker de vidro e em seguida 
foi acrescentado álcool isopropílico até que as amostras ficassem totalmente cobertas. O Becker foi posicionado na lavadora por ultrassom.

No ultrassom, os punções e as sequências de forjamento permaneceram 15 minutos submersos em álcool isopropílico. Após este tempo, as ferramentas foram retiradas do Becker e lavadas com água corrente. O recipiente foi lavado e novamente preenchido com álcool isopropílico, de forma a repetir o mesmo procedimento por mais 15 minutos.

Após o segundo ciclo de limpeza por ultrassom, foi utilizado um secador, com sopro de ar quente durante 5 minutos para secagem os corpos de prova.

\subsubsection{Embutimento}

O embutimento foi feito nas pontas dos punções e nas sequências de forjamento em que as seções transversais seriam analisadas no MEV. Foram feitos 6 corpos de provas embutidos (PCP, P100, P500, P1000, P2000 e P10000) e 3 corpos de prova da sequência de forjamento na embutidora Buehler SimpliMet 30 do LFS, apresentada na Figura 36.

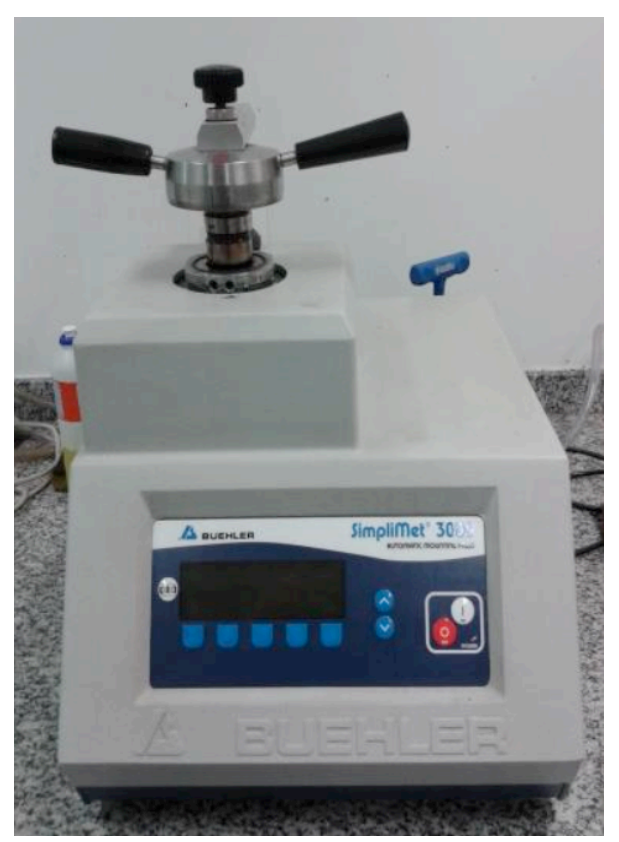

Figura 36 - Embutidora Buehler SimpliMet 30 do LFS. 
O embutimento foi feito com resina fenólica ${ }^{13}$ Multifast Green reforçado para melhorar a região limítrofe entre a ferramenta e o polímero. Assim, procurou-se evitar o efeito de borda ${ }^{14}$ durante as análises no MEV. Este cuidado também proporciona uma melhor preparação do corpo de provas durante o lixamento evitando que ocorresse o desnível ou abaulamento entre a superfície da ferramenta e a do baquelite devido à diferença de dureza entre os materiais.

\subsubsection{Lixamento e polimento automático}

As amostras foram lixadas de modo a preparar a superfície para o polimento. Todas as amostras foram lixadas manualmente com lixas d'água com granulometrias de 320, 400, 600 e 1200 Mesh. Cada lixa foi utilizada até obter-se uma superfície homogênea e com os riscos provenientes do lixamento alinhados em um único sentido, no mesmo sentido de giro da lixa.

Após todas as lixas terem sidos utilizadas, posicionou-se os corpos de prova na politriz automática Struers TegraPol-25, apresentada na Figura 37 junto com os corpos de prova polidos. A politriz automática utiliza um sistema magnético de fixação dos panos de polimento. Nos panos de polimento, foram utilizadas pastas diamantadas com granulometrias de $9 \mu \mathrm{m}, 3 \mu \mathrm{m}$ e $1 \mu \mathrm{m}$. Cada corpo de prova foi polido durante 10 minutos com cada pano, até a total eliminação dos riscos.

\footnotetext{
${ }^{13}$ Resina fenólica é popularmente conhecida como baquelite.

${ }^{14}$ Efeito de borda é causado pela difração dos raios $\mathrm{x}$ de maneira desorientada durante as análises no $\mathrm{MEV}$, dificultando a recepção dos raios $\mathrm{x}$ pelo filtro do microscópio eletrônico. Este efeito é causado pelo arredondamento da região limítrofe da superfície objeto de estudo com a resina, baquelite, utilizada no embutimento.
} 

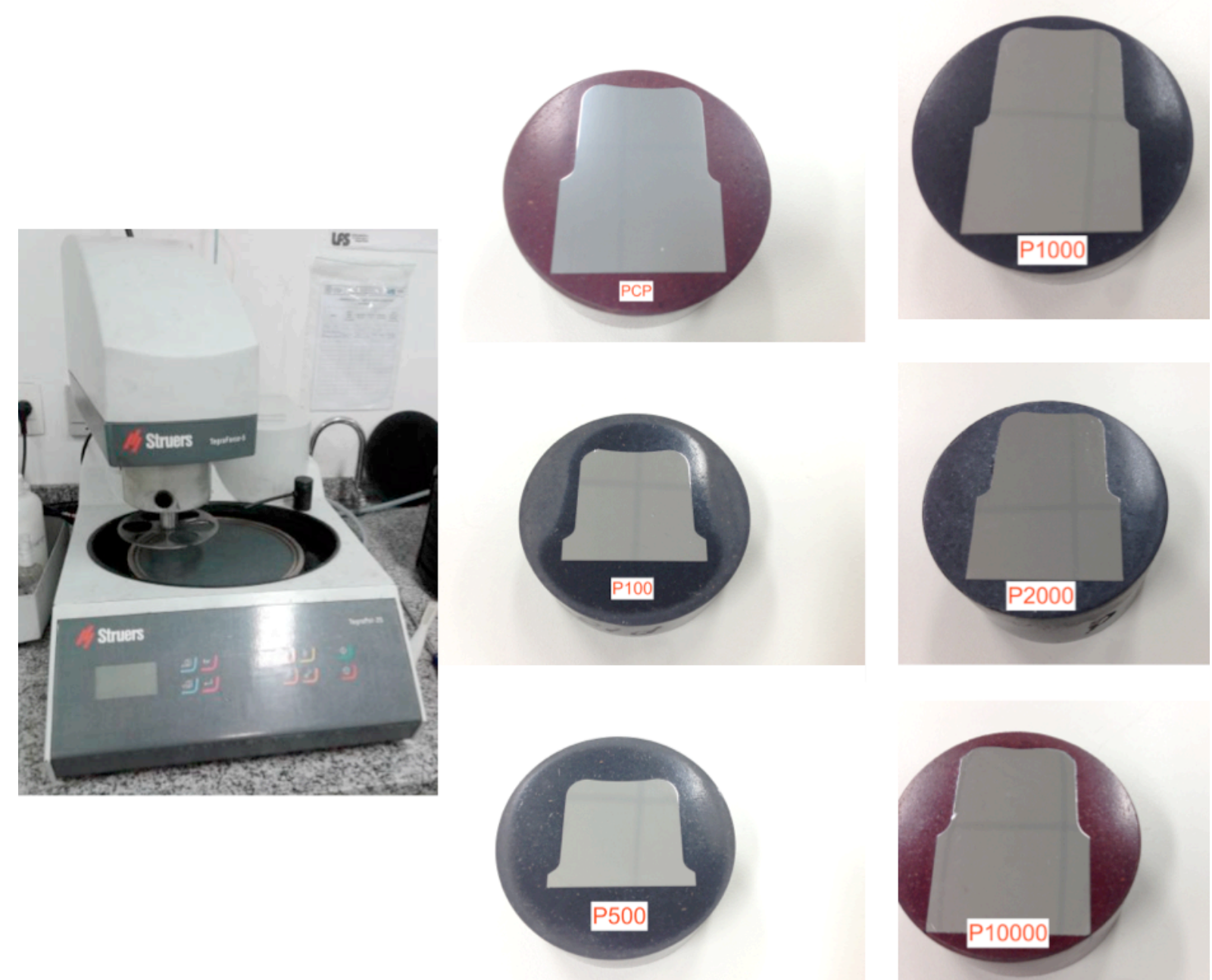

Figura 37 - Politriz automática Struers do LFS utilizada na preparação das amostras dos punções.

O mesmo procedimento foi repetido para a sequência de forjamento que seria analisada no MEV.

\subsubsection{Ataque químico}

As amostras embutidas que seriam utilizadas no MEV, foram atacadas com nital $5 \%$ por 15 segundos. Este ataque foi realizado para obter-se o contraste entre os carbonetos e a matriz martensítica do aço ferramenta. A Figura 38 apresenta a amostra PCP. Em (a), antes o ataque, e em (b), após o ataque. 

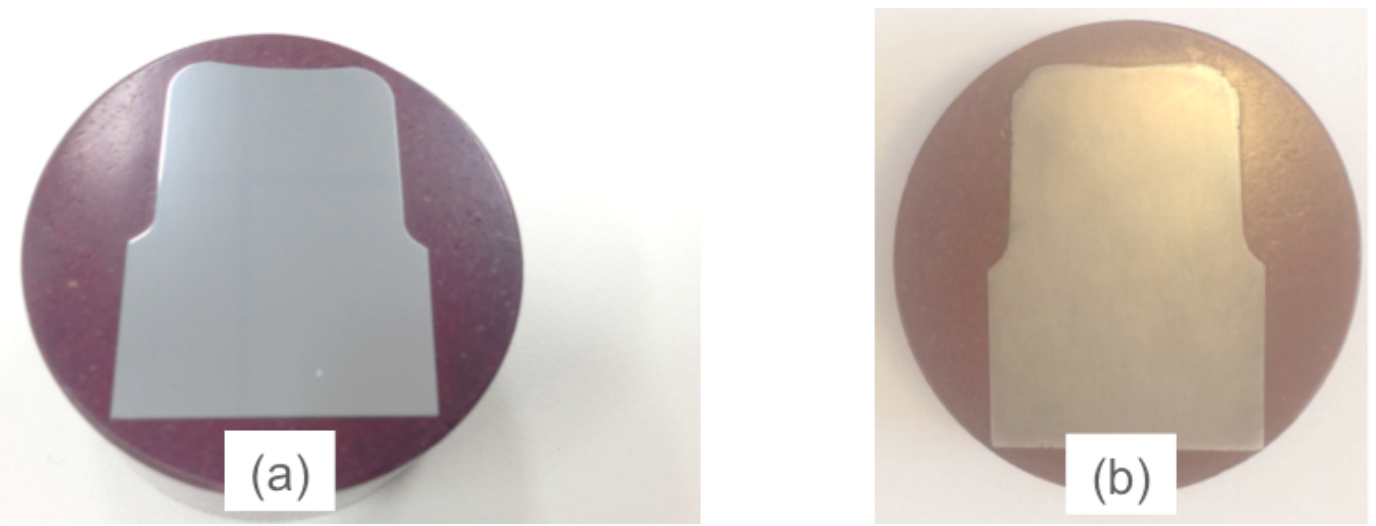

Figura 38 - Amostra submetida ao ataque químico com nital 5\%. Em (a) amostras polida sem ataque químico. Em (b), amostra polida com ataque químico.

Logo após o ataque, os copos de provas foram lavados em água corrente durante 10 segundos e secos com secador, com sopro de ar quente durante 1 minuto, para que nenhum resíduo líquido ou sólido ficasse nas amostras e prejudicasse as análises no MEV.

O mesmo procedimento foi seguido para o ataque químico das seções transversais das sequências de forjamento.

\subsubsection{Microscopia eletrônica de varredura}

As doze amostras dos seis punções foram analisadas no MEV, sendo seis amostras das superfícies e seis para análise da seção transversal. Nas amostras, analisou-se a microestrutura, além de vestígios de material aderido, riscos sulcos e trincas. O MEV utilizado nas análises, foi da marca Jeol, modelo JSM6010, apresentado na Figura 39, instalado no LFS da EPUSP. 


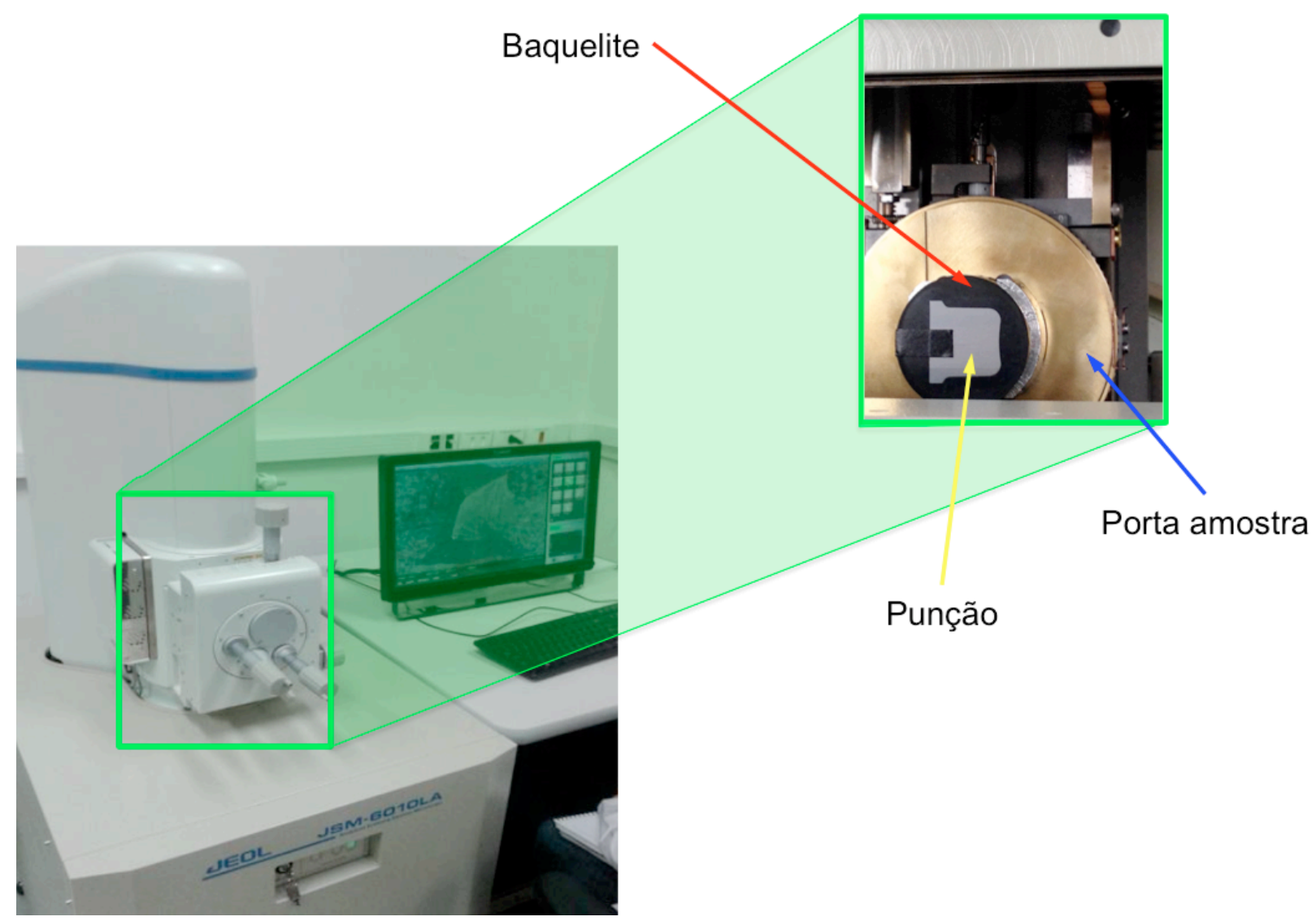

Figura 39 - Microscópio eletrônico de varredura - MEV JEOL JSM6010 instalado no LFS.

No MEV foram utilizados dois tipos de detetores destinados à captação de elétrons: detetor para elétrons retro espalhados (BSE) e o detetor para elétrons secundários (SE).

O sensor para detecção dos elétrons retroespalhados, foi utilizado para obter imagens cuja a tonalidade está associada ao peso atômico dos materiais presentes na superfície e nas seções transversais das amostras. Com o sensor para detecção dos elétrons secundários foi possível observar a topografia da superfície e caracterizar os modos de desgaste existentes na região da análise.

Análises de espectroscopia por dispersão de energia de raios $\times$ (EDS) foram igualmente feitas, para análise semi-quantitativa dos elementos químicos presentes em algumas regiões das amostras. 


\subsubsection{Medição da nanodureza}

A nanoindentação foi feita no equipamento Tribolndenter-TI 950, fabricado pela empresa Hysitron. A geometria da ponta utilizada para realizar as impressões nos corpos de prova foi do tipo Berkovich $[59,60]$. As medições de nanodureza foram feitas nas amostras preparadas com as seções transversais dos punções utilizados no forjamento. A Figura 40 apresenta: Em (a) a visão geral do nanoindentador; em (b), a área interna do equipamento onde são feitas as impressões e em (c) a mesa onde as amostras foram posicionadas e coladas com cola Super Bonder evitar que se deslocassem no momento de realizar as impressões, gerando leituras equivocadas e imprecisas.

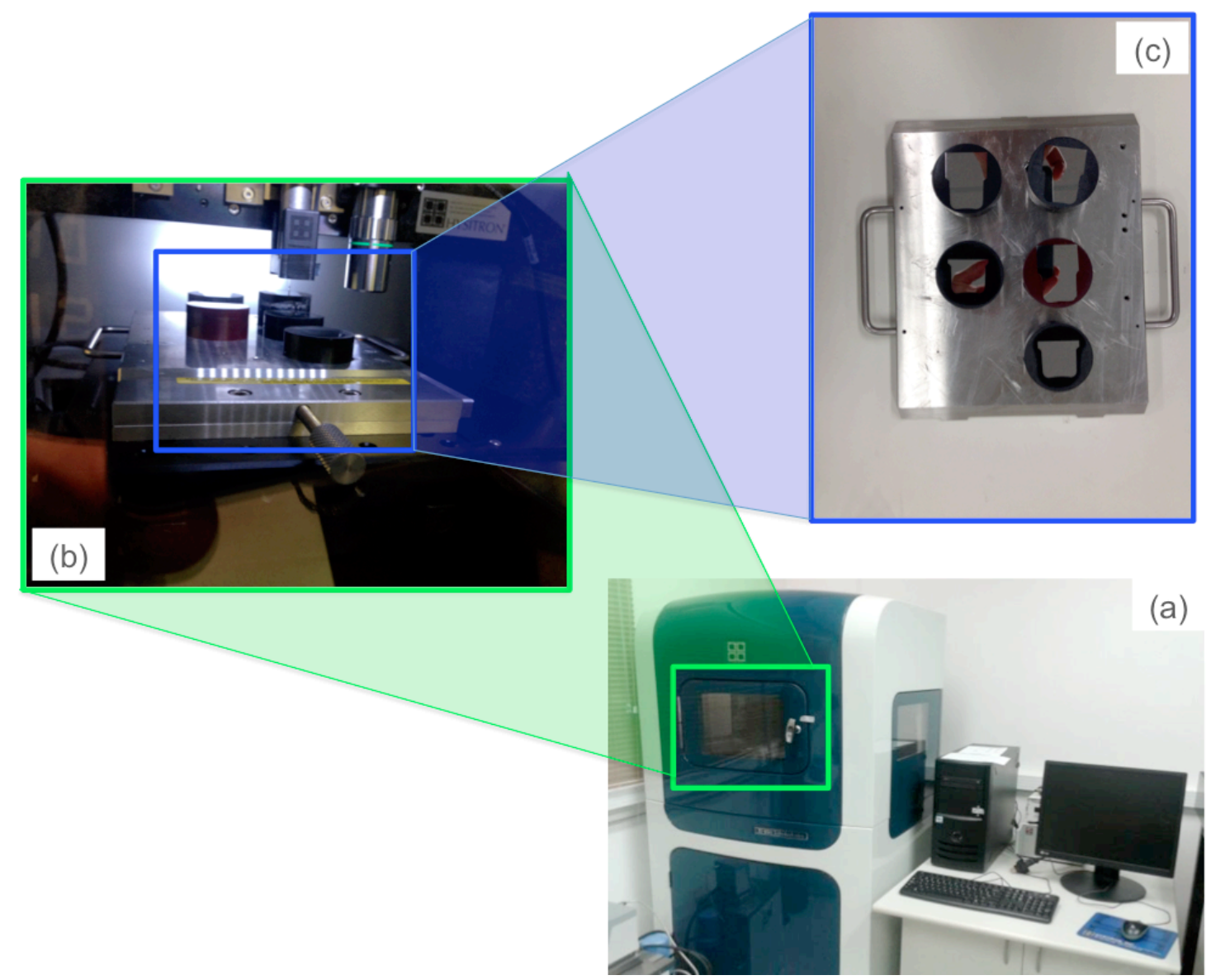

Figura 40 - Triboindentador Hisytron TI950 do LFS: (a) Visão geral do equipamento. (b) Detalhe da área interna onde são feitas as impressões. (c) detalhe da mesa com as amostras posicionadas.

Para realizar as impressões, nas seções transversais, foi utilizada a carga de $5000 \mu \mathrm{N}$ com o ciclo de: tempo carregamento de 10 segundos, tempo de 
impressão de 10 segundos e tempo de descarregamento em 10 segundos, conforme diagrama apresentado na Figura 41.

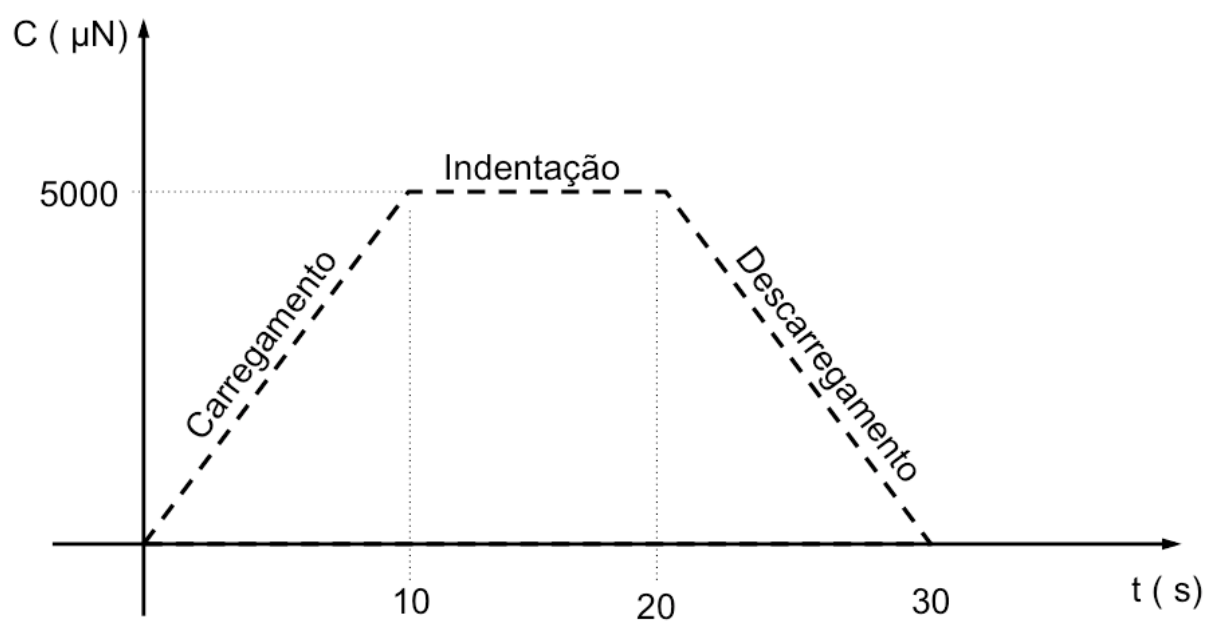

Figura 41 - Diagrama do ciclo de impressão utilizado no Triboindentador Hisytron TI950. 


\section{RESULTADOS E DISCUSSÕES}

O acompanhamento do forjamento das porcas abrangeu cerca de 13600 peças produzidas com a mesma corrida de matéria prima.

O resultado deste acompanhamento está descrito nos tópicos seguintes e evidencia a presença de diferentes modos de desgaste em uma mesma ferramenta de forjamento a quente utilizada em prensa mecânica automática horizontal de múltiplos estágios de conformação.

\subsection{Análise Dimensional dos Punções}

A medição das dimensões da ponta dos punções serviu de base de comparação e constatação do desgaste em cada uma das ferramentas. Com o resultado das medições verificou-se, conforme afirmação de SOUZA, que ocorreu a perda de massa, a mudança indesejada na geometria da ferramenta e um dano acumulativo ao longo do tempo de utilização [19].

Após medir os punções, antes e após o forjamento, foi feita a comparação dimensional por meio de um gráfico com o resultado das variações das medidas $C$, $\mathrm{RD}, \mathrm{E}, \mathrm{RF}, \mathrm{H}$ e I dos cinco punções utilizados no forjamento (Figura 42). Os únicos punções que não sofreram mudança dimensional foram os punções P100 e P500. Nos demais punções, todas as dimensões controladas sofreram alteração dimensional. A dimensão $\mathrm{RD}$, que é o raio de concordância entre a lateral e o topo do punção, aumentou gradativamente entre o P1000 e P2000, porém abruptamente entre os P2000 e o P10000. A dimensão $C$ aumentou, diminuiu e voltou a aumentar nos punções P1000, P2000 e P10000, respectivamente. A dimensão RF foi a que apresentou a maior variação. Evidenciada no punção P1000, sua medida após o forjamento foi maior que a obtida originalmente antes do forjamento. No P2000, diminuiu em relação ao P1000, apesar de ainda estar acima da medida original da ferramenta. No punção P10000, houve uma diminuição brusca, tanto em relação aos punções P1000 e P2000, quanto em relação ao próprio punção P10000 antes de ser 
utilizado no forjamento. A medida $\mathrm{H}$, que é a diferença de altura na parte superior do punção, ficou estável entre os punções P1000 e P2000, porém menor que as dimensões originais encontradas. No P10000, atingiu o menor valor, reduzindo de $0,496 \mathrm{~mm}$ para $0,373 \mathrm{~mm}$. 


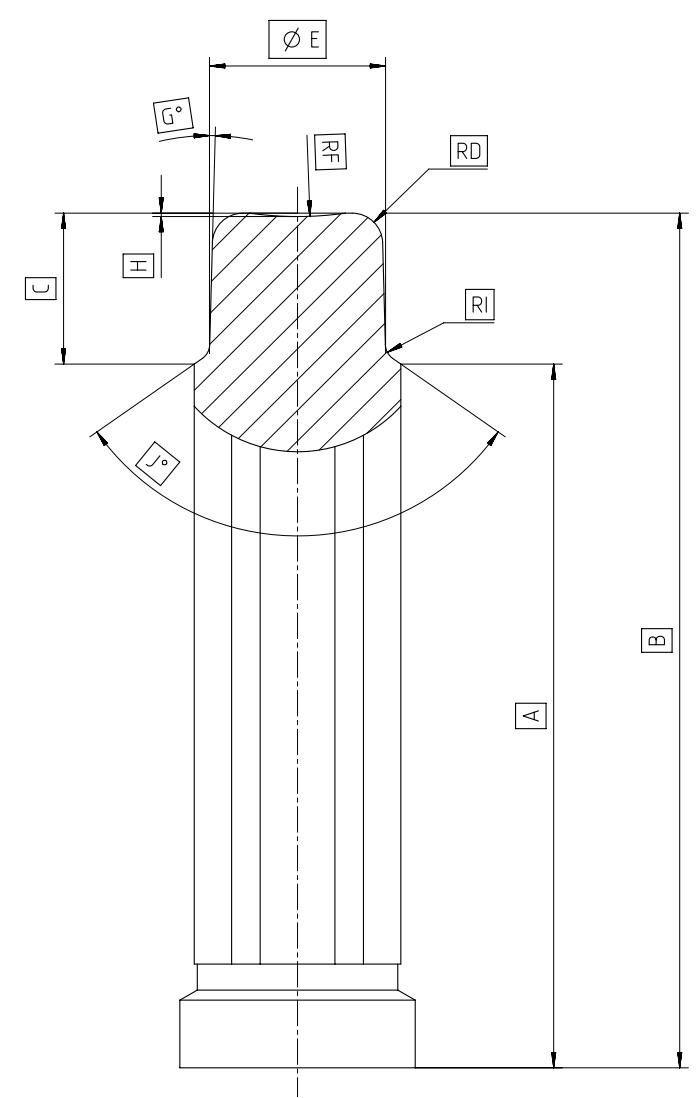

COMPARAÇÃO DAS DIMENSÕES DOS PUNÇÕES ANTES E DEPOIS DO FORJAMENTO

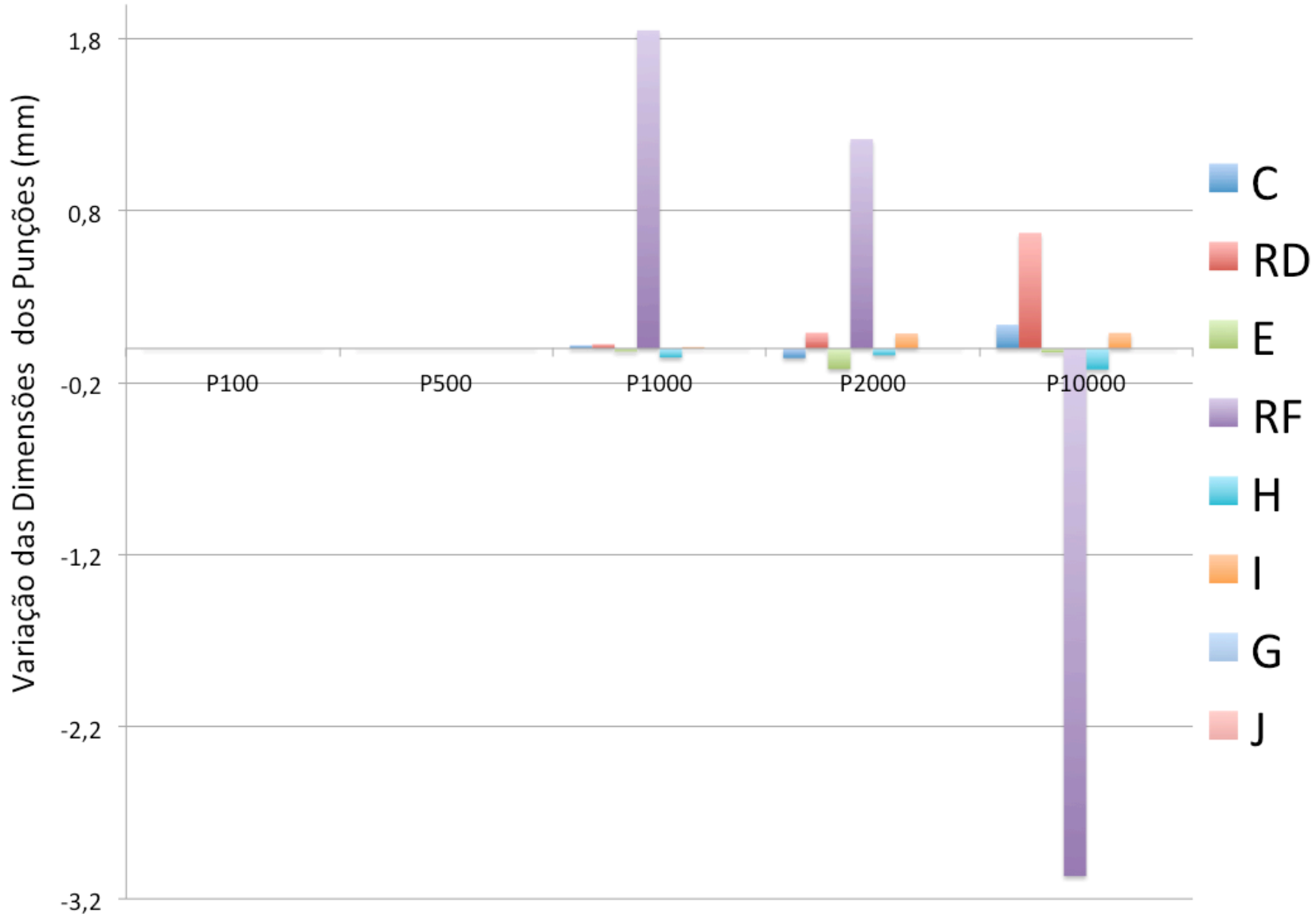

Figura 42 - Resultado da variação dimensional dos punções após o forjamento. 
A variação da massa também é uma constatação do desgaste. Comparando-se a massa dos punções, percebe-se que os punções P100 e P500 não sofreram alteração significativa, nem positiva, nem negativa de massa. $O$ punção P1000, sofreu um acréscimo de $0,0002 \mathrm{~kg}$ em relação a sua massa original. Já o punções P2000 e P10000, perderam material, representado uma perda de massa de 0,0002 kg e 0,0005 kg, respectivamente, em comparação com as massas originais de cada um, conforme apresentado no gráfico de perda de massa dos punções na Figura 43.

RESULTADO DA VARIAÇÃO DE MASSA PUNÇÕES

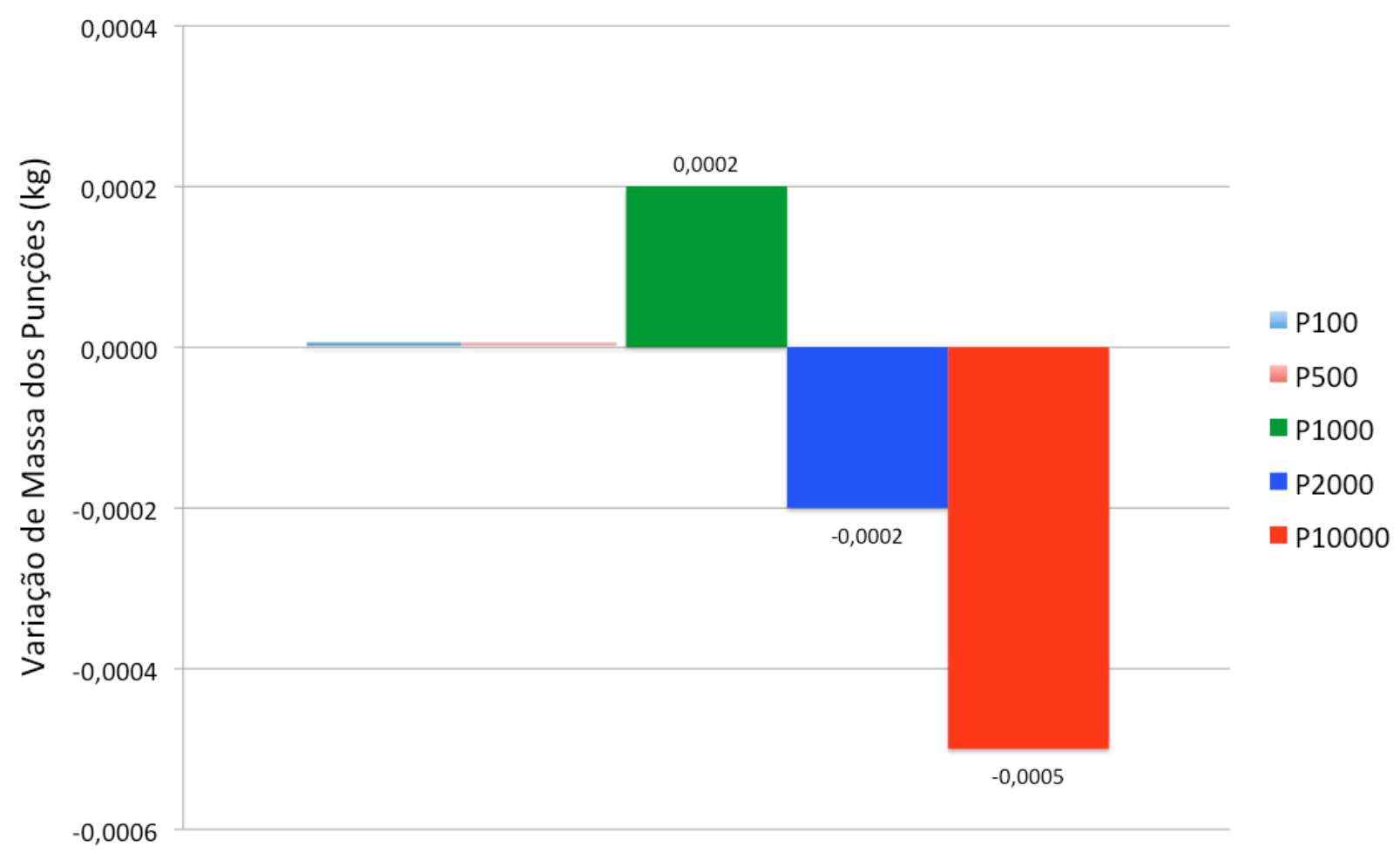

Figura 43 - Comparação da variação da massa dos punções.

\section{2. $\quad$ Aspecto das Superfícies dos Punções}

As ferramentas foram fotografadas antes e após o forjamento. Elas foram dispostas lado a lado para serem comparadas umas com as outras e com elas mesmas, de forma a viabilizar o estudo da evolução do desgaste (Figura 44). 
A comparação das pontas dos punções permitiu afirmar que houve uma mudança significativa no aspecto geral das superfícies devido aos danos gerados no forjamento.

Ao analisar os punções P100, P500, P1000, P2000 e P10000, observa-se que o dano causado em cada um deles foi acumulativo e progressivo, ou seja, quanto mais peças forjadas com um punção, maior foi o dano aparente na superfície, conforme a revisão sobre desgaste feita por SOUZA [19]. A coloração das superfícies sofreu alteração perceptível a olho nu. Deixou de apresentar coloração cinza clara para adquirir coloração cinza escura, o que pode ter sido causado pela exposição às temperaturas elevadas utilizadas no forjamento das porcas.

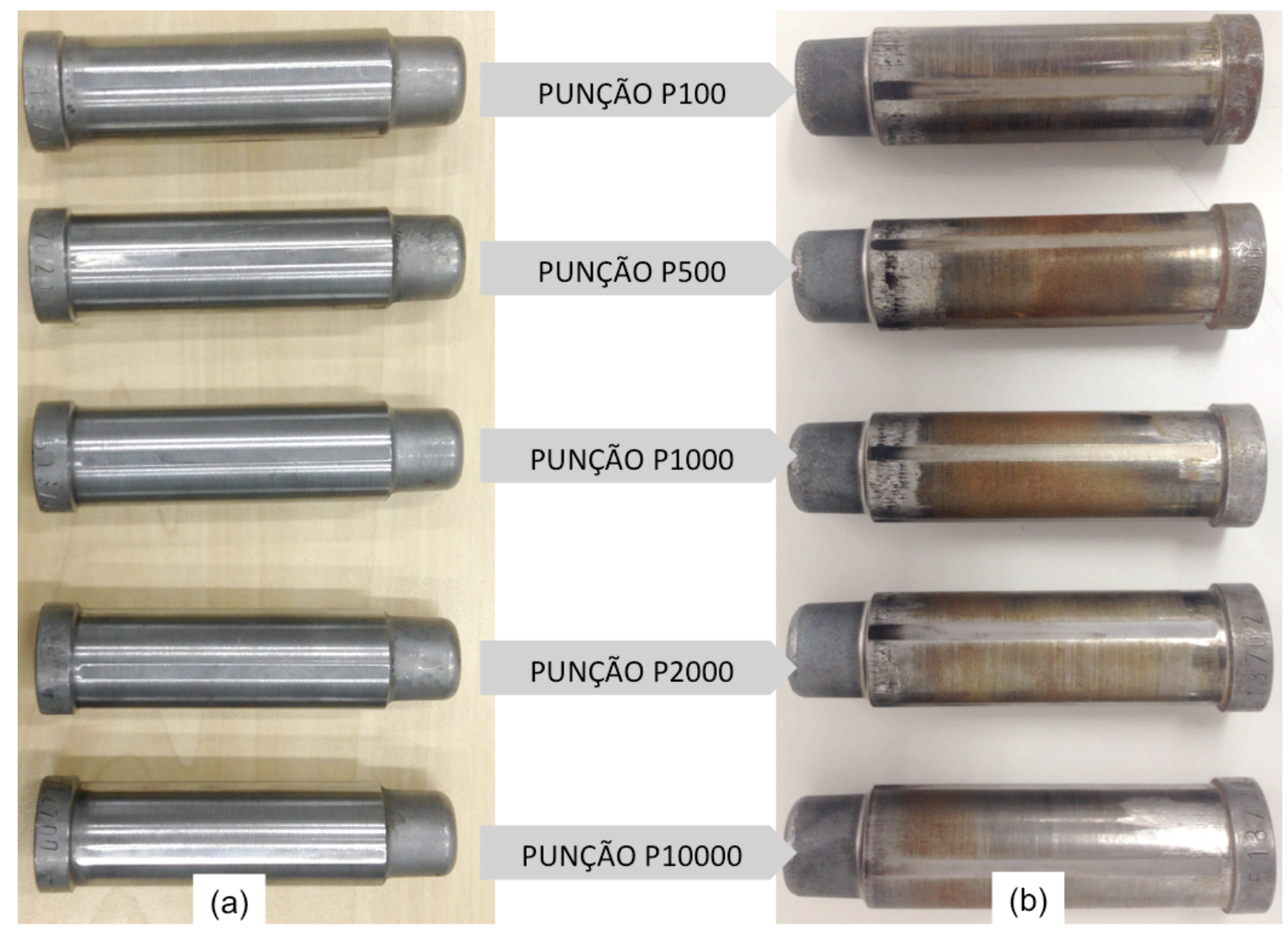

Figura 44 - Punções utilizados nos forjamentos: (a) punções antes do forjamento; (b) os punções após a utilização no forjamento. 
Os corpos dos punções apresentaram uma oxidação em determinadas regiões devido à exposição da ferramenta ao sistema de refrigeração da prensa utilizada.

Observando mais de perto a superfície de contato dos punções com o blank, percebeu-se a presença de características de desgaste a quente em ferramentas, tanto no topo das pontas dos punções quanto nas laterais.

$\mathrm{Na}$ Figura 45, as seções transversais dos punções foram dispostas de tal forma a possibilitar a observação do topo das pontas dos punções, na vista superior e a lateral deles, na vista lateral. Em (a), o punção P100 já apresenta pequenas trincas na parte superior e marcas de desgaste que sugerem abrasão e adesão na lateral da ferramenta, porém existe uma região superior que não apresenta degradação. Em (b), o punção P500 já apresenta uma evolução da degradação na parte superior com pequenas trincas em toda superfície. A lateral apresenta o mesmo padrão com assinatura de desgaste abrasivo e adesivo. Em (c), o punção P1000 já apresenta um padrão superficial característico de ferramentas que sofreram fadiga térmica devido a propagação de trincas térmicas. Na lateral do punção, observa-se mais características de adesão e uma diminuição do padrão de desgaste abrasivo com riscos e sulcos. Em (d), o punção P2000 evidencia a evolução da fadiga térmica em determinadas regiões da parte superior e poucos riscos devido à abrasão. Na lateral, observa-se adesão na maior extensão junto com abrasão localizada na parte mais inferior superfície de contato. Em (e), o punção P10000 já está com a parte superior da ferramenta com aspecto característico de desgaste devido à fadiga térmica, apresentando aspecto de leito de rio seco e certas regiões com adesão. A região de concordância do raio apresenta riscos evidentes na direção de avanço do punção contra o blank, no sentido de forjamento. A lateral do punção apresenta mais característica de material aderido com acúmulos em determinadas regiões e quase nenhuma característica de desgaste abrasivo. 


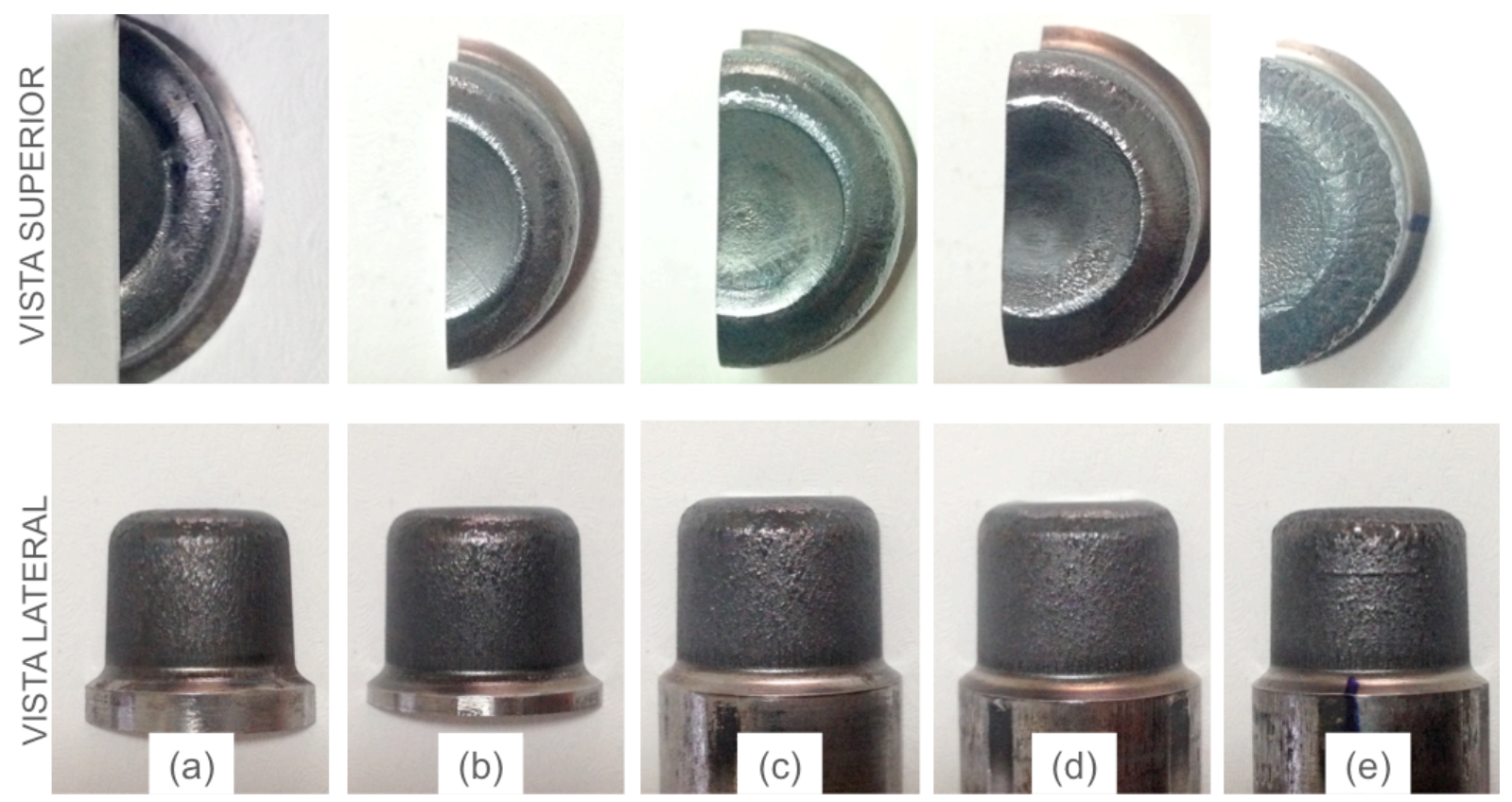

Figura 45 - Avaliação das superfícies dos punções após o forjamento: (a) P100; (b) P500; (c) P1000; (d) P2000; (e) P10000.

Ainda que a superfície dos punções tenha sofrido, desde o P100 até o P10000, uma notória alteração, é difícil precisar qual foi o modo de desgaste responsável pelo dano presente em cada das seções transversais. Inclusive, há amostras que certamente desgastaram-se por mais de um modo de desgaste. É possível observar, ainda, que houve uma diferença de modos de desgaste diferentes em regiões distintas das pontas dos punções e o aspecto da superfície assemelhase a adesão e abrasão.

\subsection{Análise da Superfície do Punção}

Com alteração perceptível na superfície dos punções, esperava-se a alteração da rugosidade, criando uma diferença entre o punção novo em relação ao punção usado. Foram utilizados os parâmetros de rugosidade $R_{a}$ e $R_{z}$ para medir e comparar os resultados encontrados em cada um dos punções.

A comparação das rugosidades revelou uma alteração na superfície dos punções, tendo sido encontrados valores superiores nos punções usados, tanto para valores $R_{\mathrm{a}}$, quanto para valores $R_{z}$. Esta alteração foi gradual ao longo do tempo até o punção P1000. Os resultados dos punções P2000 e P10000 mostraram-se 
ligeiramente menores, com tendência de diminuírem, se comparados com os outros três punções.

A Tabela 12 mostra os valores de rugosidade dos seis punções, PCP, P100, P500, P1000, P2000 e P10000.

Tabela 12 - Comparação da rugosidade nos punções usados em comparação com o punção PCP.

\begin{tabular}{|c|c|c|c|c|c|c|c|c|}
\cline { 2 - 9 } \multicolumn{1}{c|}{} & \multicolumn{2}{c|}{$\mathbf{4 5}^{\mathbf{0}}$} & \multicolumn{2}{c|}{$\mathbf{1 3 5}^{\mathbf{2}}$} & \multicolumn{2}{c|}{$\mathbf{2 2 5}^{\mathbf{2}}$} & \multicolumn{2}{c|}{$\mathbf{3 1 5}^{\mathbf{0}}$} \\
\cline { 2 - 9 } & $\mathbf{R a}(\mu \mathrm{m})$ & $\mathbf{R z}(\mu \mathrm{m})$ & $\mathbf{R a}(\mu \mathrm{m})$ & $\mathbf{R z}(\mu \mathrm{m})$ & $\mathbf{R a}(\mu \mathrm{m})$ & $\mathbf{R z}(\mu \mathrm{m})$ & $\mathbf{R a}(\mu \mathrm{m})$ & $\mathbf{R z}(\mu \mathrm{m})$ \\
\hline PCP & 2,02 & 10,59 & 1,88 & 9,45 & 1,93 & 9,88 & 1,95 & 10,54 \\
\hline P100 & 5,06 & 36,35 & 5,25 & 31,3 & 7,69 & 39,9 & 5,53 & 38,31 \\
\hline P500 & 5,43 & 35,74 & 5,76 & 36,29 & 7,73 & 38,99 & 5,11 & 31,77 \\
\hline P1000 & 3,35 & 34,9 & 7,65 & 45,88 & 5,05 & 31,34 & 5,93 & 46,74 \\
\hline P2000 & 5,46 & 31,17 & 8,37 & 45,62 & 4,61 & 29,63 & 5,3 & 32,87 \\
\hline P10000 & 4,98 & 22,64 & 7,48 & 34,89 & 4,14 & 18,64 & 6,8 & 31,62 \\
\hline
\end{tabular}

A alteração na superfície dos punções, comprovada pelos resultados de rugosidade, $\mathrm{Ra}$ e $\mathrm{Rz}$, em conjunto com as imagens, ganha força quando as superfícies dos punções foram observadas no MEV. No entanto, quando avaliadas isoladamente, as alterações na rugosidade da superfície de contato não transmitem informações completas do desgaste sofrido.

A Figura 46 compara a superfície dos seis punções, PCP, P100, P500, P1000, P2000 e P10000, utilizando o detector BSE, onde é possível acompanhar a evolução da degradação na superfície a medida que o número de peças forjadas aumenta. Em (a), observa-se as marcas de usinagem na superfície do punção PCP, características do avanço e da profundidade de corte da pastilha de usinagem. Em (b), a superfície do punção $\mathrm{P} 100$ já apresenta alteração significativa e as marcas de usinagem já não fazem mais parte da topografia do punção. Existe, na superfície do punção $\mathrm{P} 100$, regiões destacadas com a tonalidade cinza claro, indicadas pelas setas vermelhas, o que evidencia a diferença do peso atômico dos materiais presentes na superfície. Em (c), na superfície do punção P500 é possível notar a presença de trincas, indicadas pelas setas azuis, e regiões da superfície com peso atômico distinto são menores e aparecem menor quantidade, tendendo a ter uma coloração homogênea e, possivelmente composta por um material apenas. Em (d), 
aparentemente, as trincas se propagaram pela superfície do punção P1000 aparentando ter aumentado a quantidade de trincas. A concentração de trincas é maior e obedecem uma formação de retângulos, definidos por quatro trincas que se cruzam. Já as regiões destacadas por terem peso atômico diferentes diminuíram significativamente. Em (e), a quantidade de trincas no punção P2000 aumentou ligeiramente em relação ao punção P1000. As regiões destacadas com pesos atômicos diferentes reduziram-se a duas bem destacadas, sugerindo uma superfície quase totalmente composta pelo mesmo material. Em (f), a superfície do punção P10000 não apresenta o mesmo aspecto que as dos punções anteriores. Nela, a quantidade de trincas diminuiu e surgiram sulcos e deformações na direção de avanço do punção contra o blank, ou seja, na direção do forjamento. A tonalidade é a mesma para toda a superfície analisada do punção. 

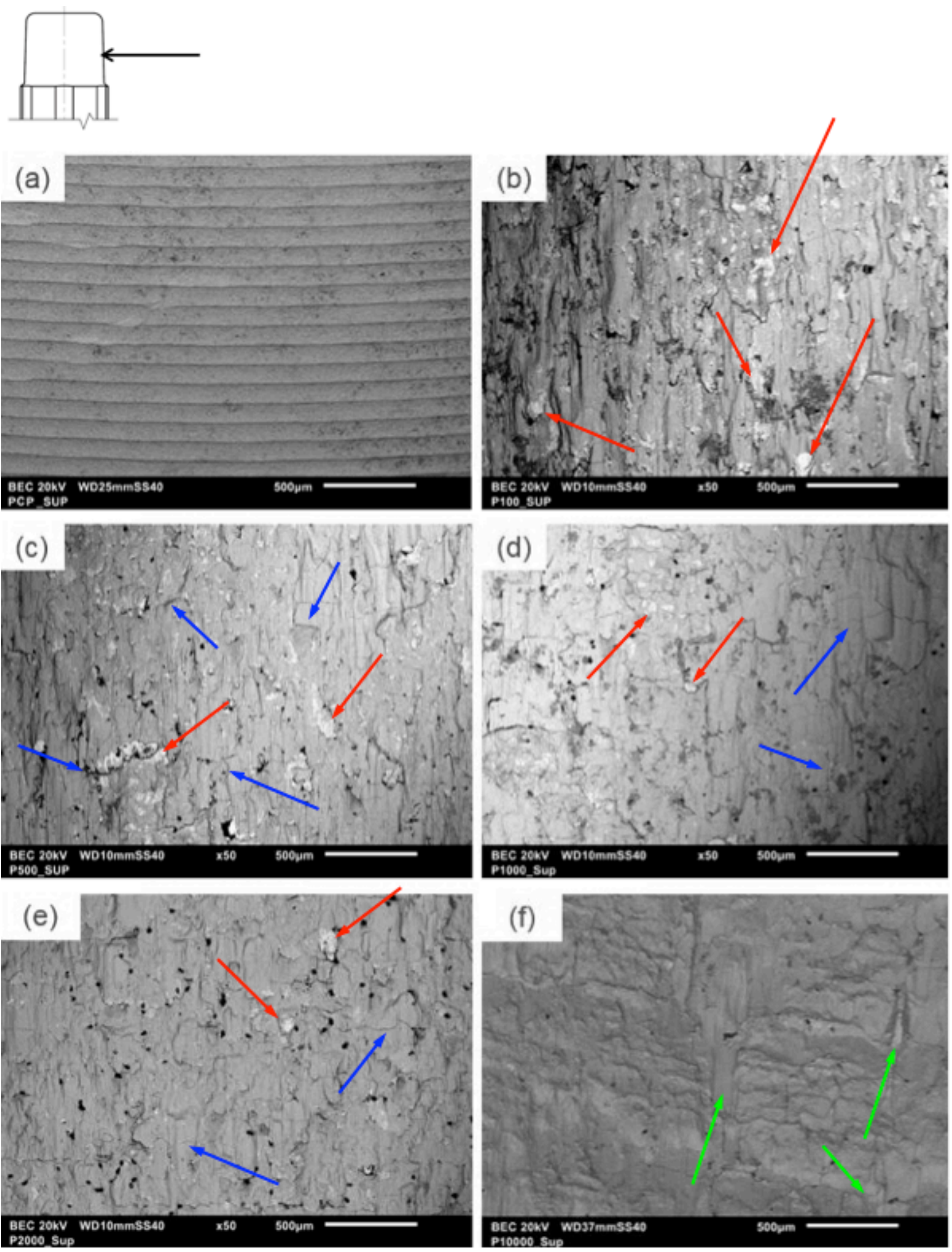

Figura 46 - Análise das superfícies dos punções, detector BSE com aumento 50x: (a) Punção PCP: (b) Punção P100; (c) Punção P500; (d) Punção P1000; (e) Punção P2000; (f) Punção P10000. 
Para avaliar a topografia da superfície dos punções, foi utilizado o detector para a captação dos elétrons secundários - SE, proporcionando imagens das mesmas superfícies dos punções que serviram de base de comparação entre os punções utilizados no forjamento com o punção PCP.

De uma maneira geral, o padrão superficial alterou-se em todos os punções utilizados no forjamento quando comparados com o punção PCP. A Figura 47 apresenta a comparação da topografia das superfícies dos punções, PCP, P100, P500, P1000, P2000 e P10000. Em (a) a topografia da superfície do punção PCP evidencia as marcas de usinagem e duas regiões com deformações nas franjas de usinagem, que podem indicar batidas na ferramenta. Em (b), a topografia do punção P100 não segue o perfil da superfície do punção PCP. As marcas de usinagem foram totalmente removidas e inicia-se um padrão topográfico na direção de avanço do punção. Em (c), a superfície do punção P500 apresenta-se com regiões que aparentam ser patamares. Em (d), o punção P1000 apresenta uma superfície semelhante ao punção P500 porém com patamares menores Em (e), a topografia do punção P2000 se assemelha ao perfil encontrado no P1000. No entanto, a quantidade de sulcos mais profundos e deformações é maior e os patamares praticamente foram eliminados. Em (f), existem sulcos alinhados na direção de avanço do punção e há regiões que se comparam com superfícies que sofreram adesão. 

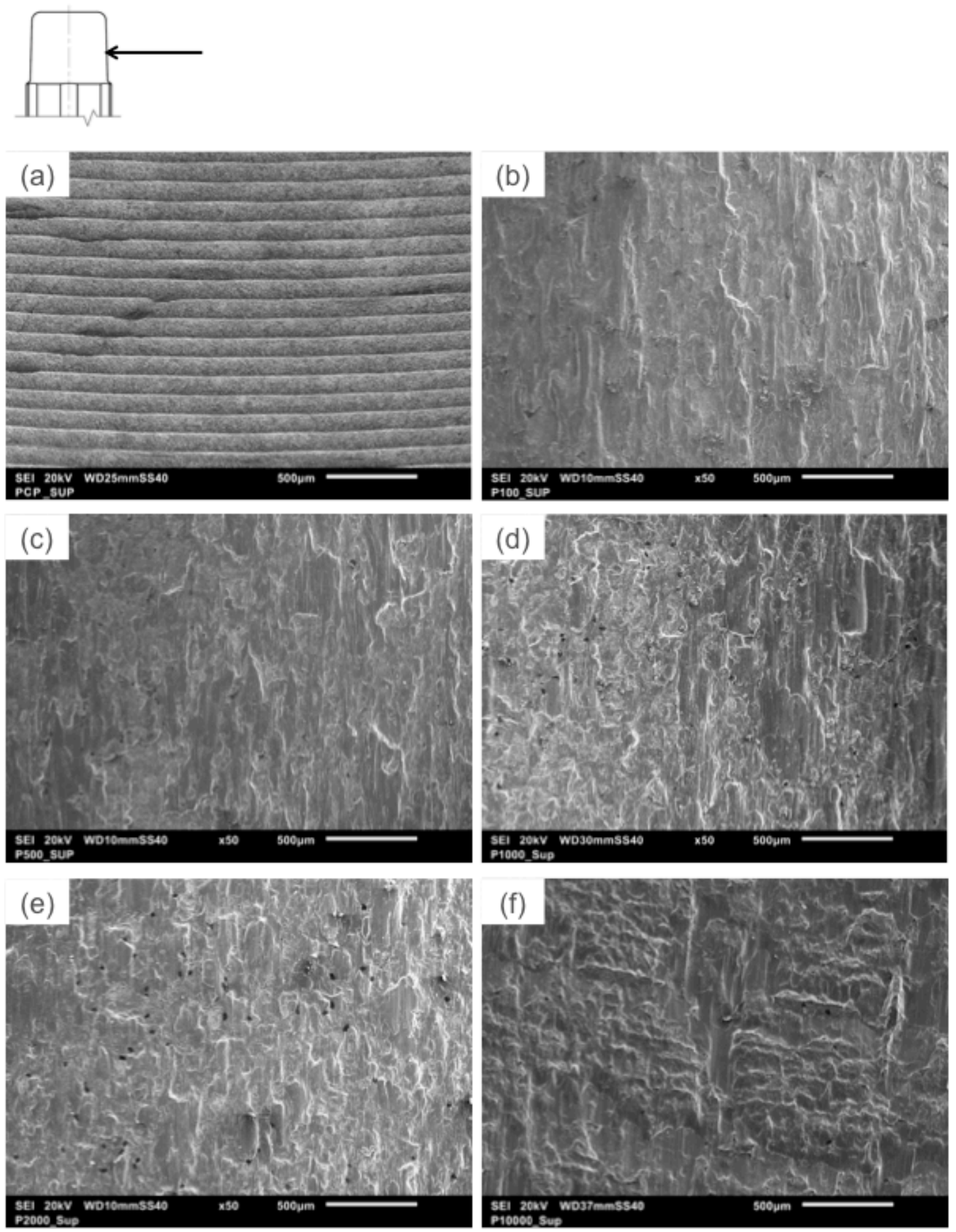

Figura 47 - Análise da topografia da lateral dos punções. Detector SE com aumento 50x: (a) PCP; (b) P100; (c) P500; (d) P1000; (e) P2000; (f) P10000. 
Com aumento maior, utilizando-se as mesmas superfícies, buscou-se encontrar evidências da presença dos mecanismos de desgaste responsáveis pelos danos encontrados na superfície dos punções. Nesta análise utilizou-se o detector BSE com aumento de 500x. Com este aumento foi possível encontrar diferentes modos de desgaste na mesma região da ferramenta, variando de acordo com a quantidade de peças forjadas com o punção. Foram encontrados riscos e sulcos, que podem ter sido causados por partículas abrasivas soltas, ou debris, na interface, além de trincas observadas antes. Os riscos e os sulcos presentes na superfície dos punções apresentaram-se alinhados com o sentido de deslocamento da ferramenta, no sentido do forjamento. Em determinadas regiões onde foram encontrados sulcos, encontrou-se trincas perpendiculares ao sentido de deslocamento da ferramenta indicando o surgimento de tensões trativas na superfície, possivelmente ligadas à abrasão a dois corpos (Figura 10).

A Figura 48, apresenta a sequência de imagens feitas para cada punção. Em (a), tem-se uma imagem obtida com o punção PCP, onde mais uma vez é possível observar as marcas de usinagem, indicadas pelo contraste das duas linhas horizontais escuras. Em (b), na superfície do punção P100, observa-se a presença de trincas pequenas, indicadas pelas setas azuis. Em (c), a superfície do punção P500 apresenta mais trincas e regiões onde a diferença de peso atômico é evidenciada pela tonalidade mais clara, indicadas pelas setas vermelhas, peso atômico maior. Em (d), observa-se uma fotografia obtida com o punção P1000 onde as regiões de coloração distinta são menores. Em (e), tem-se informações referentes ao punção P2000, onde observa-se, também, uma região com tonalidade mais clara, indicada pela seta vermelha, além da presença de riscos e sulcos, indicados pelas setas verdes, alinhados na direção de avanço do punção contra o blank. Em (f), o punção P10000 apresenta um sulco central profundo. Com largura entre $100 \mu \mathrm{m}$ e $110 \mu \mathrm{m}$ de largura, o sulco está alinhado com o movimento de avanço do punção contra o blank e dentro do sulco existem riscos e sulcos também alinhados com o movimento do punção, que estão indicados pelas setas verdes e ainda algumas trincas, indicadas pelas setas azuis. 

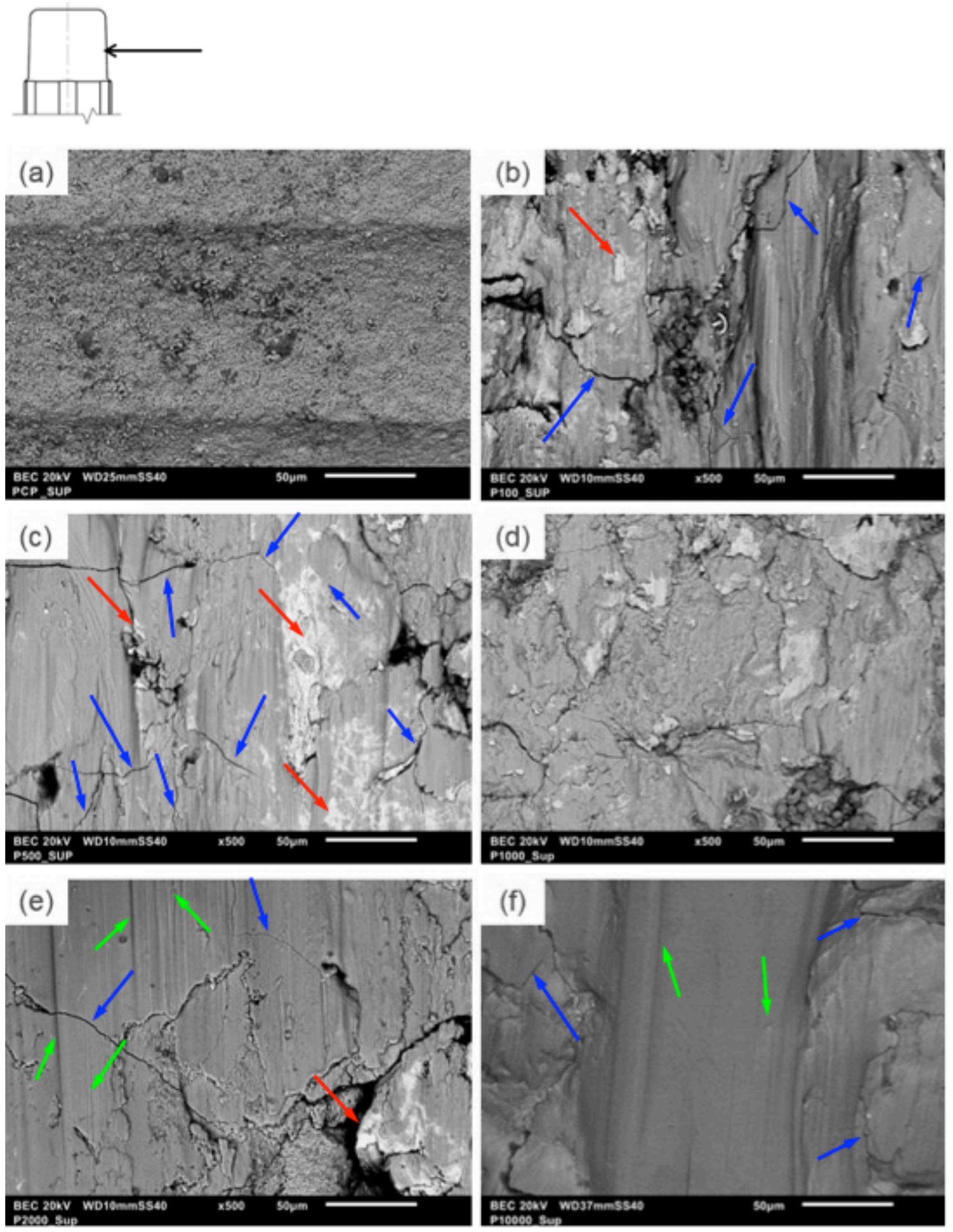

Figura 48 - Análise da topografia da lateral dos punções. Detector BSE com aumento 500x. (a) PCP; (b) P100; (c) P500; (d) P1000; (e) P2000; (f) P10000. 
A técnica de EDS foi usada para avaliar a diferença de coloração presente em algumas regiões dos punções, o que poderia indicar a presença de diferentes materiais na superfície dos punções.

Foram feitas três análises sobre a superfície dos punções: PCP, P1000 e P10000. Primeira análise foi feita na superfície do punção PCP. Nela foram escolhidos quatro pontos espalhados pela superfície do punção, conforme mostrado na Figura 49.

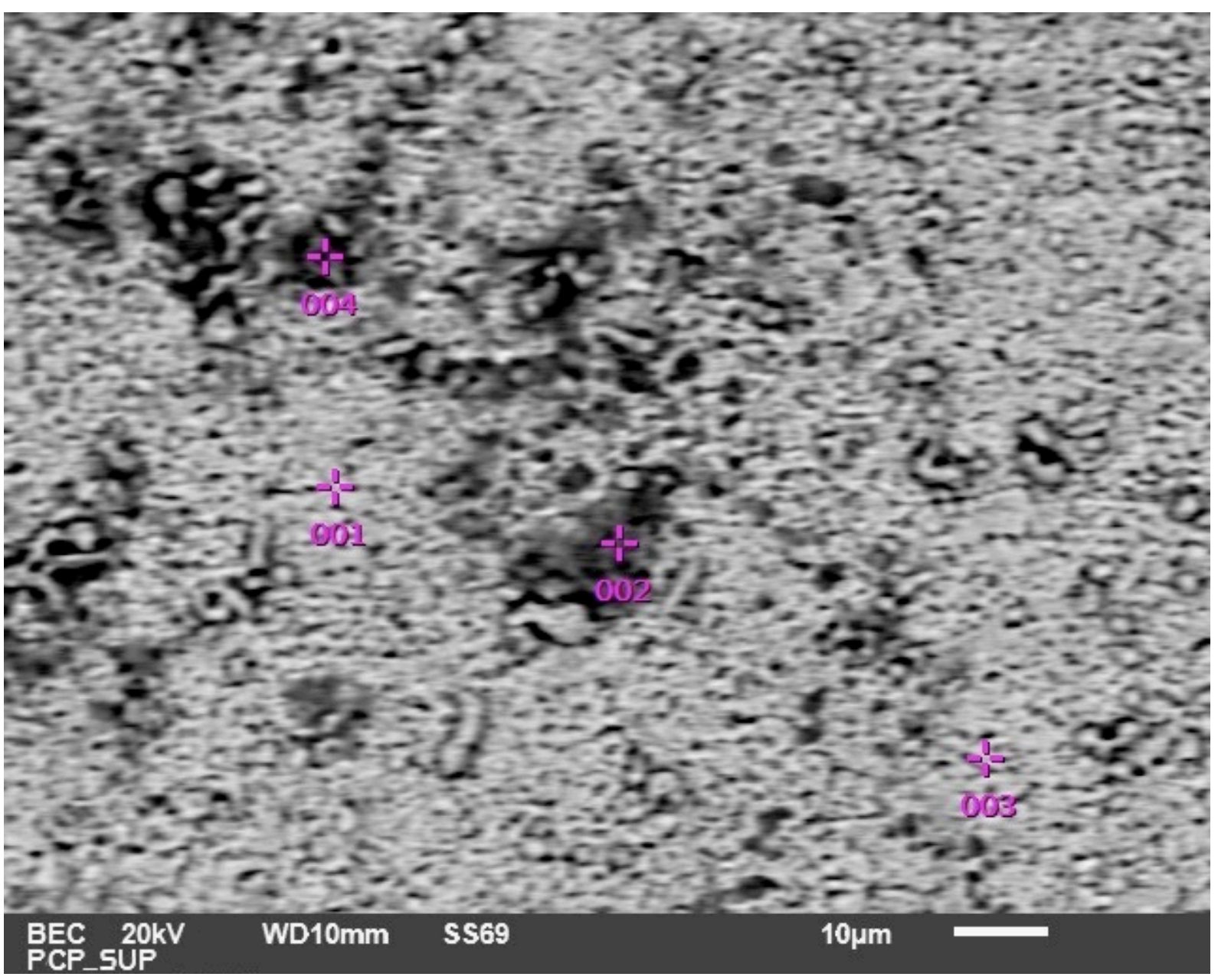

Figura 49 - Análise EDS da superfície do punção PCP

$\mathrm{Na}$ tabela 13, foram expostos os resultados das composições químicas encontrada em cada ponto escolhido. 
Tabela 13 - Composição química da superfície do punção PCP obtida por EDS

\begin{tabular}{|c|c|c|c|c|c|c|c|c|c|c|c|c|c|}
\cline { 2 - 14 } \multicolumn{1}{c|}{} & Fe & K & O & Na & Mg & Al & Si & S & Cl & Ca & V & Cr & Mo \\
\hline 001 & 95.97 & - & - & - & 0.15 & - & 0.09 & 0.03 & - & - & 0.20 & 3.54 & 0.02 \\
\hline 002 & 77.30 & 0.19 & 17.86 & 0.39 & 0.16 & - & 0.26 & 0.08 & 1.53 & 0.12 & 0.16 & 1.68 & 0.27 \\
\hline 003 & 91.96 & - & 1.77 & - & 0.33 & - & 0.24 & 0.02 & - & - & 0.46 & 5.05 & 0.18 \\
\hline 004 & 80.13 & 0.14 & 13.53 & 0.42 & 0.47 & 0.11 & 0.44 & 0.10 & 0.68 & 0.14 & 0.29 & 3.38 & 0.17 \\
\hline
\end{tabular}

Apesar do resultado obtido de concentração química em cada ponto não ser exatamente que o esperado para o aço $\mathrm{H} 10$, as concentrações dos elementos de liga $\mathrm{Cr}$ e V estão coerentes com o aço H10 [20]. Já o Mo foi encontrado na superfície do punção, porém com concentração menor que o esperado. Com exceção do ponto 001, os demais indicaram a presença de óxido na superfície do punção PCP.

Nas duas avaliações seguintes esperava-se encontrar composição química coerente com a do aço $\mathrm{H}-10$, utilizado na fabricação dos punções, em todos os pontos escolhidos. No entanto verificaram-se algumas discrepâncias em relação à composição esperada.

A escolha do punção P1000 foi baseada na presença de regiões com pesos atômico diferentes, sugerindo a existência de diferentes materiais. A Figura 50 apresenta o posicionamento dos seis pontos utilizados para ser feita a análise EDS. 


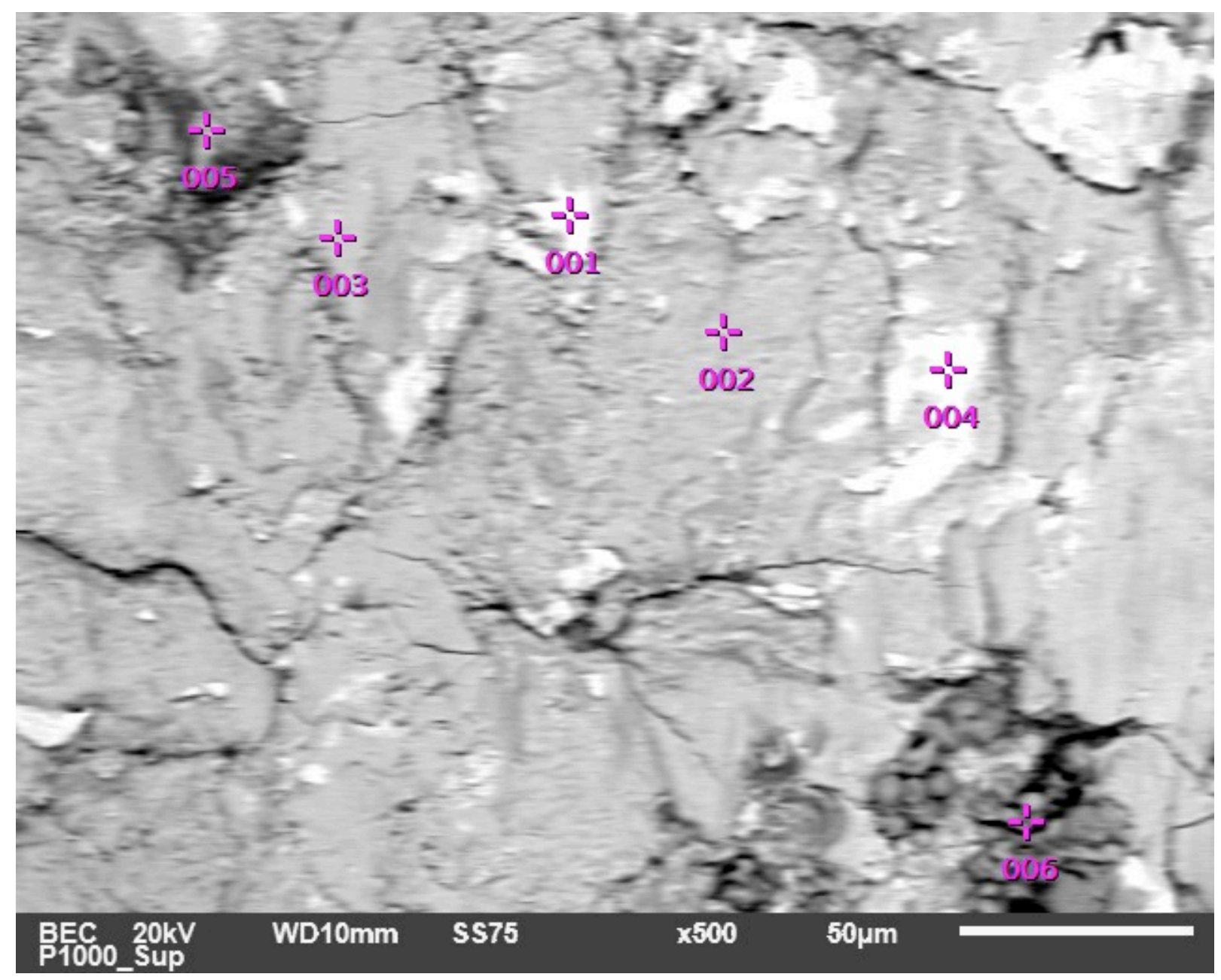

Figura 50 - Análise EDS da superfície do punção P1000.

$\mathrm{Na}$ Tabela 14, foram expostos os resultados da composição química encontrada em cada um dos seis pontos analisados por EDS.

Tabela 14 - Composição química da superfície do punção P1000 obtida por EDS

\begin{tabular}{|c|c|c|c|c|c|c|c|c|c|c|c|c|c|c|c|}
\cline { 2 - 18 } \multicolumn{1}{c|}{} & $\mathbf{P}$ & $\mathbf{F e}$ & $\mathbf{K}$ & $\mathbf{O}$ & $\mathbf{N a}$ & $\mathbf{M g}$ & $\mathrm{Al}$ & $\mathbf{S i}$ & $\mathbf{S}$ & $\mathbf{C l}$ & $\mathbf{C a}$ & $\mathbf{V}$ & $\mathbf{C r}$ & $\mathbf{M n}$ & Mo \\
\hline 001 & - & 97,29 & - & 1,12 & - & - & - & 0,17 & - & - & - & - & 0,44 & 0,97 & - \\
\hline 002 & 0,48 & 80,5 & - & 15,88 & - & 0,17 & - & 0,53 & - & - & 0,8 & - & 0,46 & 1,2 & - \\
\hline 003 & 0,22 & 80,21 & - & 16,54 & - & - & - & 0,57 & - & - & 0,31 & - & 0,58 & 1,58 & - \\
\hline 004 & - & 87,16 & - & 5,8 & - & 0,49 & - & 0,98 & - & - & 0,8 & 0,26 & 2,09 & 0,44 & 1,98 \\
\hline 005 & 1,71 & 71,98 & 0,08 & 17,04 & 0,56 & 1,6 & - & 2,27 & - & - & 3,62 & - & 0,35 & 0,79 & - \\
\hline 006 & 0,23 & 64,71 & 0,53 & 28,71 & 1,16 & 0,13 & 0,11 & 0,46 & 0,18 & 0,41 & 2,32 & - & 0,33 & 0,71 & - \\
\hline
\end{tabular}

Com exceção do ponto 004, que apresentou uma concentração de cromo maior, porém abaixo da especificação do aço $\mathrm{H}-10$, os demais pontos apresentaram pouca, ou quase nenhuma, concentração dos elementos de liga, $\mathrm{Cr}, \mathrm{V}$ e $\mathrm{Mo}$, em alguns pontos, cerca de $90 \%$ menor do que a especificação de cromo. 
Adicionalmente, observa-se que a porcentagem de oxigênio foi menor nos pontos 001 e 004, que correspondem justamente às regiões mais claras da amostra.

O punção P10000 foi utilizado na segunda análise de EDS, porque a imagem obtida com o detector BSE mostrou uma cor homogênea em toda a superfície. Os seis pontos escolhidos para serem analisados estão destacados na Figura 51 e as composições químicas correspondentes estão dispostas na Tabela 15, que podem ser comparadas com a composição química do aço $\mathrm{H}-10$ (Tabela 11) utilizado na fabricação dos punções [20].

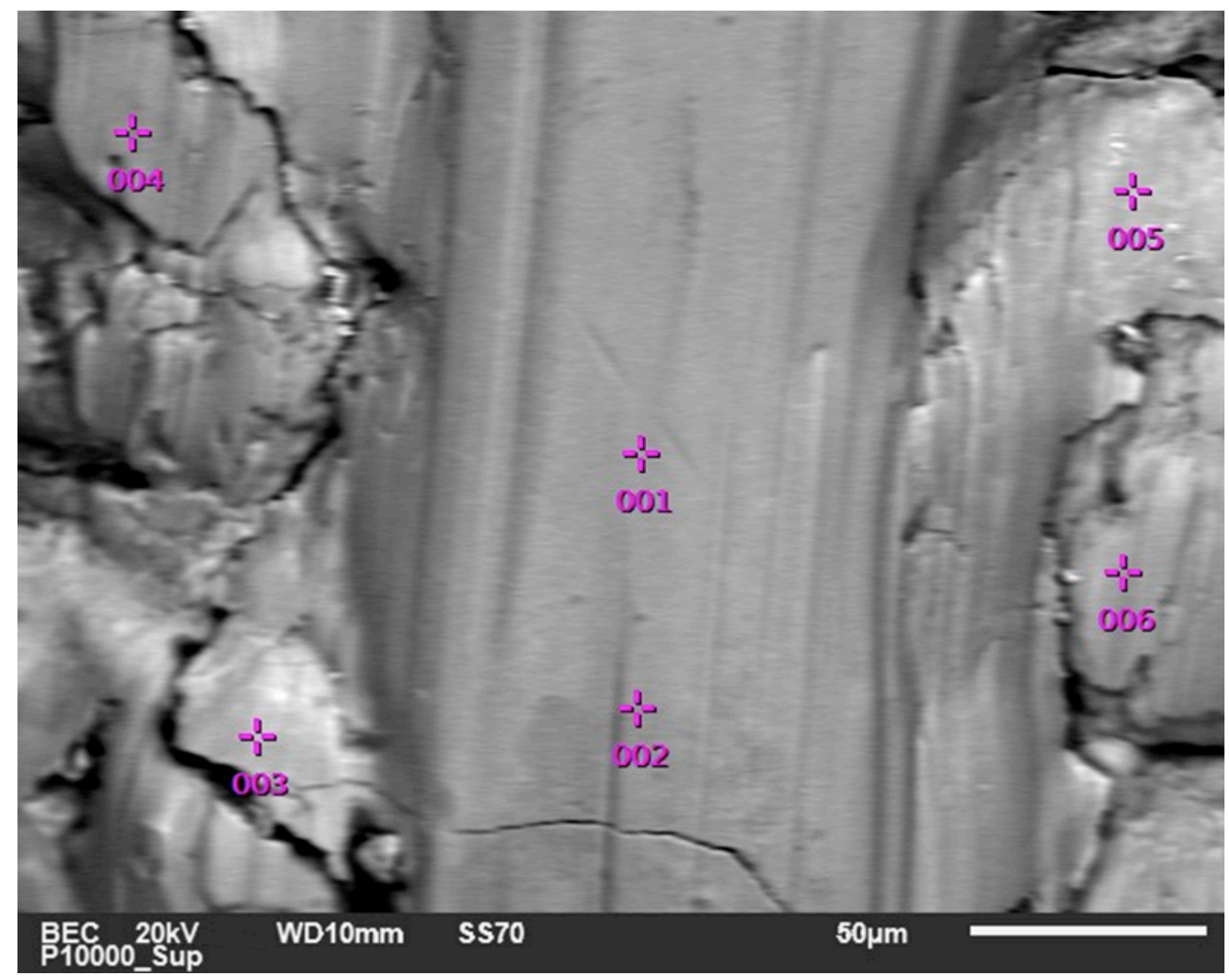

Figura 51 - Análise EDS da superfície do punção P10000.

Abaixo seguem os resultados da composição química aproximada da região analisada do punção P10000. 
Tabela 15 - Composição química da superfície do punção P10000 obtida por EDS.

\begin{tabular}{|c|c|c|c|c|c|c|c|c|c|c|c|c|c|}
\cline { 2 - 16 } \multicolumn{1}{c|}{} & P & Fe & O & Na & Mg & Al & Si & S & Ca & V & Cr & Mn & Mo \\
\hline 001 & 0,24 & 76,46 & 19,77 & 0,16 & - & 0,12 & 0,49 & - & 0,18 & 0 & 0,46 & 2,02 & 0,09 \\
\hline 002 & 0,14 & 76,99 & 20,18 & 0,37 & - & 0,08 & 0,39 & - & - & 0,03 & 0,29 & 1,46 & 0,06 \\
\hline 003 & 0,19 & 77,14 & 18,1 & 0,12 & - & 0,16 & 1,37 & - & - & 0,01 & 0,68 & 2,19 & 0,04 \\
\hline 004 & 2,44 & 63,98 & 22,96 & 0,44 & 0,55 & 0,27 & 2,39 & - & 2,72 & - & 0,91 & 3,72 & 0,22 \\
\hline 005 & 0,4 & 79,97 & 16,4 & 0,19 & 0,15 & - & 0,4 & - & 0,66 & 0,04 & 0,43 & 1,29 & 0,06 \\
\hline 006 & 0,93 & 75,11 & 19,3 & 0,21 & 0,28 & 0,1 & 0,85 & - & 1,19 & 0,06 & 0,45 & 1,47 & 0,04 \\
\hline
\end{tabular}

Mesmo a imagem mostrando materiais distintos na superfície da ferramenta, o resultado da espectrometria indicou que aquela superfície não possuía a mesma composição química esperada para uma aço-ferramenta $\mathrm{H}-10$. Este tipo de aço é da série de aços que possuem cromo na composição química, componente químico responsável pela formação de carbonetos durante o tratamento térmico.

O resultado da análise da superfície do punção P1000 foi semelhante ao resultado encontrado na análise do punção P10000. Os resultados dos pontos escolhidos apresentaram baixa fração dos elementos $\mathrm{Cr}$, Mo e V. Esta concentração baixa, indica que nas regiões analisadas a composição química da superfície não se assemelha com a especificação do aço-ferramenta $\mathrm{H}-10$.

\subsection{Análise da Seção Transversal dos Punções}

Possivelmente existindo uma camada sobre a superfície dos punções, a análise da seção transversal seria capaz de identificá-la, auxiliando a comprovar os resultados obtidos anteriormente, particularmente quanto à natureza do material aderido à superfície ferramentas.

A análise da seção transversal foi feita com o sensor BSE do MEV, com aumento de 500x. Nestas imagens observou-se que o punção PCP não apresentava camada significativamente espessa sobre a superfície. Observou-se, também, a presença de dois picos e um vale, provenientes do processo de usinagem. $\mathrm{Na}$ sequência de análises dos punções P100, P500, P1000, P2000 e P10000, verificouse a presença de camadas, que variaram de espessura conforme o número de 
peças forjadas e possivelmente podem ter sido resultado do processo de adesão sobre a superfície da ferramenta.

A Figura 52 apresenta o resultado da análise em MEV das seções transversais dos punções. Em (a), o punção PCP apresenta um perfil curvilíneo, na lateral direita da foto. Em (b), o punção P100 possui uma camada homogênea de material sobre a superfície da ferramenta e nela há uma trinca que a atravessa até encontrar a superfície do punção. Em (c), a camada de material sobre a superfície do punção P500 é mais espessa e homogênea, com mais trincas. Nitidamente, duas delas ultrapassaram a camada aderida e propagaram-se em direção ao núcleo da ferramenta. Em (d), a camada aderida na superfície do punção P1000 foi reduzida a uma espessura menor, sendo quase totalmente removida, localizada bem ao centro da imagem. Nesta imagem verificou-se, também, que a quantidade de trincas na camada aumentou sem que o comprimento delas aumentasse. Em (e), a camada sobre a superfície do punção P2000 voltou a aumentar, atingindo valores próximos a $50 \mu \mathrm{m}$. Nesta camada volta-se a observar a presença de uma trinca bem destacada que atravessa toda a camada, e algumas trincas se propagaram pela a microestrutura, em direção ao núcleo do punção. Em (f), a espessura da camada sobre a superfície do punção P10000, aparentemente, manteve-se estável. No entanto, a camada que antes era homogênea passou a ser uma camada fragmentada, composta por partículas menores. Uma trinca propagada, bem ao centro da imagem, manteve o mesmo comprimento, cerca de $60 \mu \mathrm{m}$, porém a sua largura aumentou, para cerca de $20 \mu \mathrm{m}$, e o vazio da trinca foi preenchido por material que se assemelha ao presente na superfície do punção. 

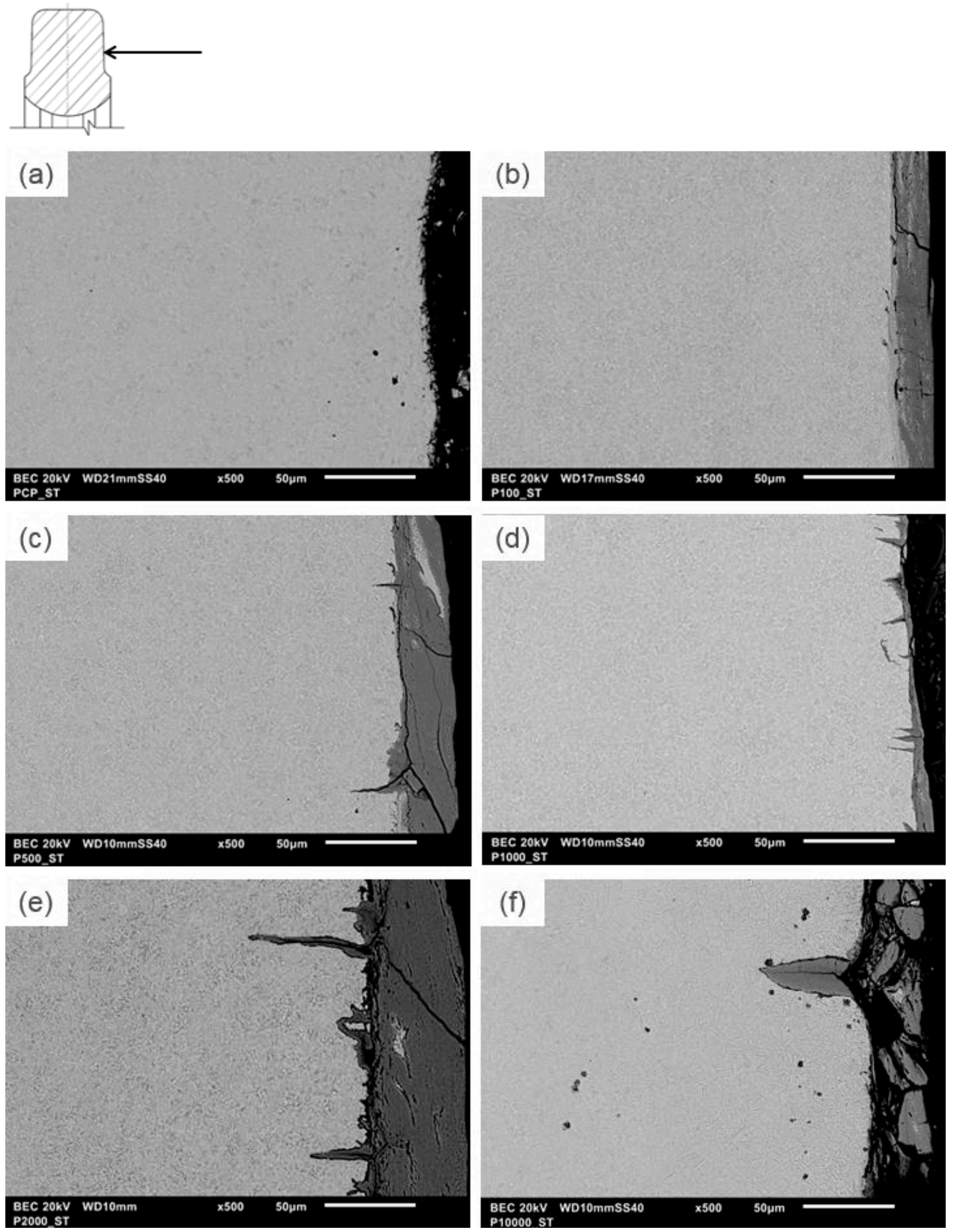

Figura 52 - Análise MEV da seção transversal dos punções utilizando detector para BSE com aumento de 500x. (a) PCP; (b) P100; (c) P500; (d) P1000; (e) P2000; (f) P10000.

Observando a sequência de imagens (Figura 52), de (b) até (f), supõem-se que houve adesão na superfície dos punções ao longo de todo os forjamentos 
devido a presença da camada observada sobre o punção. A exceção ficou para a imagem (a) que é do punção PCP, onde não observar-se nenhuma indicação de material sobre a superfície da ferramenta. As imagens (b), (c) e (e), quando comparadas com a literatura, se assemelham ao padrão de adesão onde existe sobreposição dos materiais do corpo e do contra-corpo, assemelhando-se ao que SUMMERVILLE et al. observaram e que os autores STACHOVIAK e BATCHELOR mostraram, utilizando uma gravura (Figura 9) [9,28]. A observação da presença de trincas na camada sobre a superfície do punção, que possivelmente foram causadas por fadiga térmica, no punção P100 corresponde à afirmação de SJÖSTRÖM et BERGSTRÖM, de que a nucleação de trincas térmicas ocorre com cerca de $1 \%$ da vida útil da ferramenta [42].

Os resultados das medições da espessura das camadas observadas em cada punção foi disposta em forma de gráfico e apresentado na Figura 53.

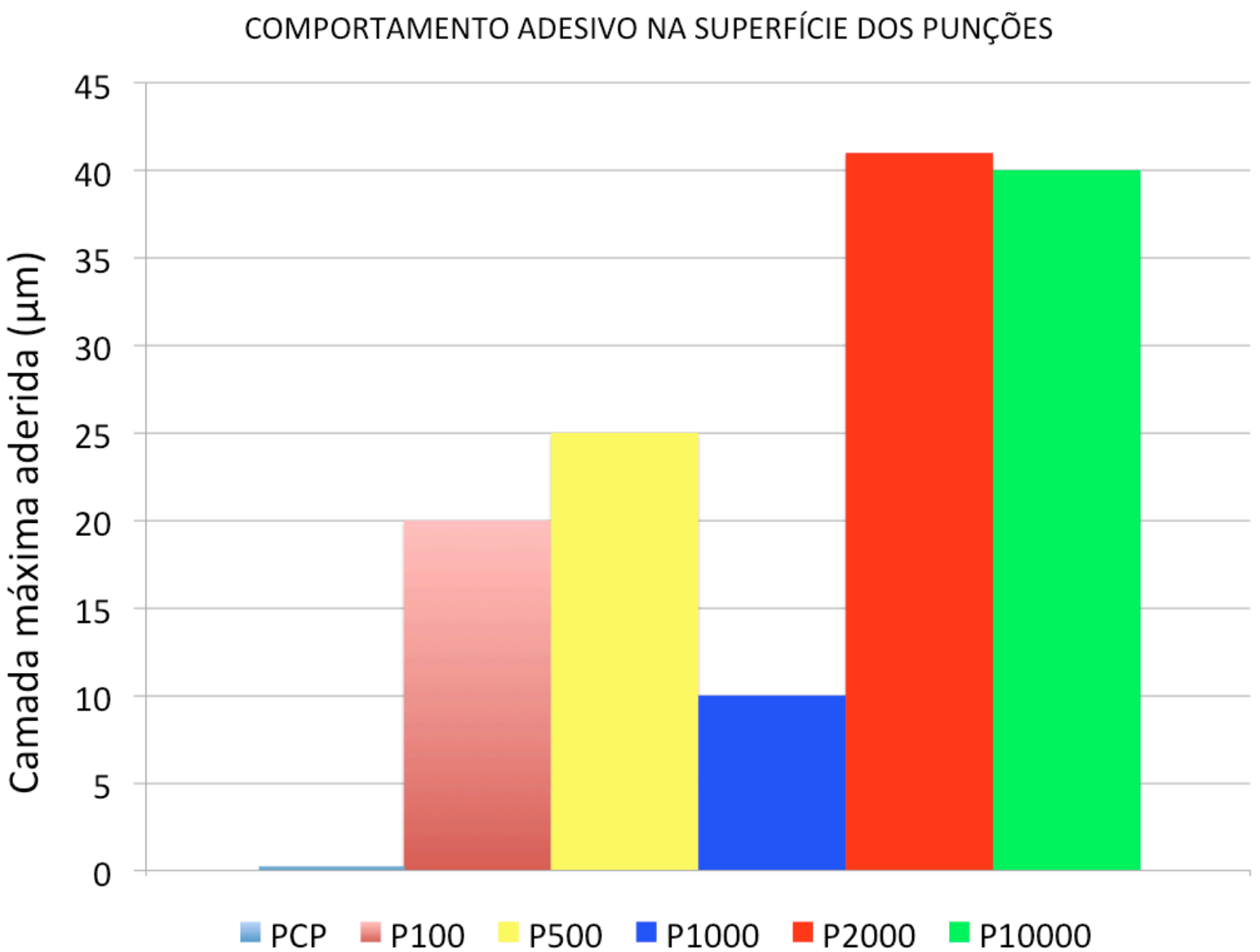

Figura 53 - Comportamento adesivo na superfície dos punções. 
Com base nas imagens da Figura 52 e nos resultados das medições da camada máxima encontrada sobre a superfície dos punções, notou-se que a espessura da camada mostra uma oscilação à medida que a quantidade de peças forjadas aumenta. Partindo de zero, ou seja, nenhuma camada sobre a ferramenta, passando pelos punções P100 e P500. O punção P1000 apresentou o menor resultado de espessura de camada dentre todos os punções utilizados no forjamento. Este comportamento observado entre os punções P500 e P1000 pode ser explicado pela remoção da camada aderida por abrasão e/ou fragmentação, que compete com a transferência de material do corpo para o contra-corpo e, também, com uma possível oxidação da ferramenta, porém é mais difícil de detectar devido as variações da liga $[9,27,28]$. Já as espessuras das camadas encontradas nos punções P2000 e P10000 mostraram-se possivelmente estáveis. No entanto não é possível afirmar com precisão se entre 2000 e 10000 peças a camada manteve-se igual, indicando uma camada máxima de óxido, ou se o processo e adesão seguido de remoção ocorreu outras vezes neste intervalo de tempo.

Embora uma camada tenha sido evidenciada na superfície dos punções, não houve aumento de massa em função do número de peças forjadas. Nos punções P2000 e P10000 as espessuras da camada foram as maiores em comparação com os outros punções. No entanto, a redução na massa original das ferramentas foram também as maiores. Esta relação de aumento da camada com a redução da massa pode ser explicado pela possível redução do diâmetro das ferramentas à medida que as camadas formadas anteriormente foram removidas, diminuindo a massa.

Além das imagens obtidas com o detector BSE, caracterizando materiais de peso atômico distintos, a camada aderida foi comprovada quando observado o resultado da espectroscopia, da seção transversal do punção P500. Nesta análise, o resultado comprovou a existência de uma camada aderida sobre a superfície do punção e que esta camada possui composição química não compatível com a especificada para o material da ferramenta. Este resultado converge com o resultado obtido pelo EDS das superfícies dos punções P1000 e P10000 (Figura 50, Figura 51, Tabela 14 e Tabela 15) que apontaram justamente para a concentrações de 
elementos de liga abaixo das especificadas para o aço $\mathrm{H}-10$ (Tabela 11) abaixo do especificado [20]. Sendo assim, pode-se supor que a camada aderida é preponderantemente proveniente do material do produto forjado.

A Figura 54 apresenta resultados referentes à composição química da seção transversal da lateral do punção P500. O mapa de elementos químicos, oxigênio (O) e ferro (Fe), reforça as observações de que houve adesão sobre a superfície do lateral punção, na faixa indicada pela seta vermelha, em (a). Esta mesma região foi analisada com relação à composição química e a concentração de ferro é mais pronunciada na região alongada que se encontra no meio da camada, indicada pela seta azul, em (b). Em (c), a concentração de oxigênio mostrou-se elevada em toda a camada aderida, com exceção da região interna e alongada que é predominantemente formada por ferro. Em (d), (e) e (f), apresentam-se os resultados da concentração dos elementos de liga do aço $\mathrm{H}-10, \mathrm{Cr}, \mathrm{V}$, Mo. Mais uma vez o resultado apontou para concentrações diferentes entre o núcleo da ferramenta e a camada aderida na superfície, mostrando que a faixa à direita das imagens, referese a material aderido, proveniente do contra-corpo, ou seja da peça conformada e sua oxidação. 

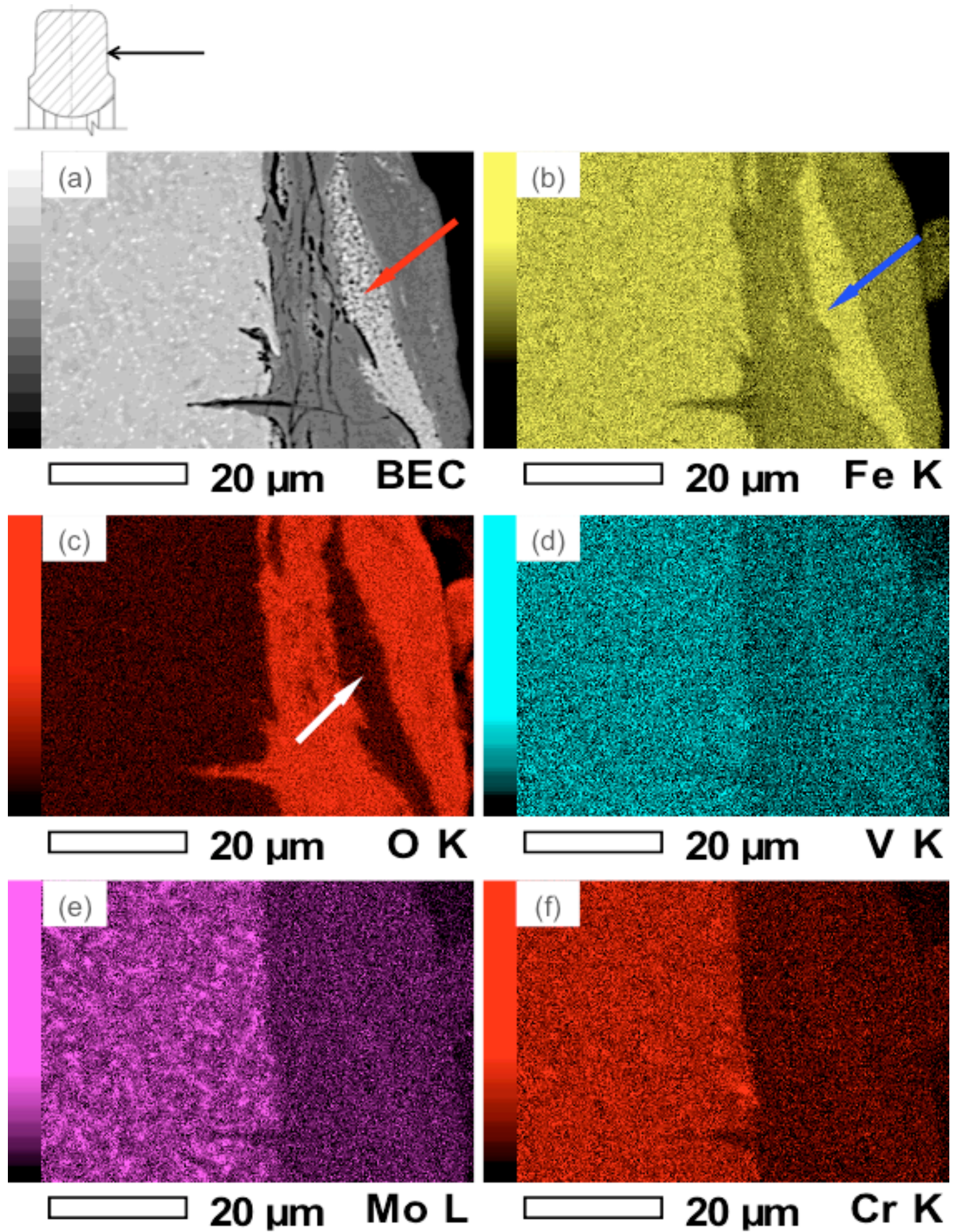

Figura 54 - EDS da seção transversal do punção P500 - Mapa de concentração de elementos químicos. (a) região analisada com detector BSE; (b) Fe; (c) O; (d) V; (e) Mo; (f) Cr.

A formação da camada observada (Figura 54) deixa mais evidente o que o acompanhamento da evolução da camada aderida na superfície evidenciou na Figura 52. A sobreposição dos materiais do tribossistema, em forma de camadas, 
assemelha-se às observações de SUMMERVILLE et al. para a formação da camada aderida por meio da mistura de materiais como óxidos, aço-ferramenta e aço do contra-corpo, seja difícil a identificação da origem da oxidação $[9,28]$.

Porém o estudo da sequência de forjamento pode trazer uma possível resposta para a origem da oxidação nas ferramentas, conforme LANGE previu [6]. A Figura 55 apresenta a sequência de forjamento utilizada na fabricação da porca, desde o blank cisalhado até a porca forjada. Em (a), considerando-se o blank de material aquecido, as linhas destacas em vermelho representam a oxidação formada durante o aquecimento da barra de aço SAE 1045, que ocorre em toda a superfície. Em (b), o blank foi deformado, na operação de recalque, para retirar a oxidação superficial e para preparar a geometria para o estágio seguinte. No entanto, mesmo proporcionando a remoção mecânica da oxidação superficial na lateral da peça, na região de contato das ferramentas, destacadas pelas linhas vermelhas, a oxidação não é eliminada devido ao contato do punção com o blank e da matriz com o blank. Consequentemente, a oxidação que não foi removida na operação de recalque é transferida junto com o blank para o próximo estágio de forjamento. Em (c), a porca forjada com as dimensões finais apresenta, destacadas pelas linhas vermelhas, as regiões provenientes do estágio anterior em que a oxidação não foi removida. A região interna da porca é a superfície de contato entre o punção de pré-furação e o blank, evidenciando como esta pode ser a fonte de óxidos que se aderem à superfície do punção ao longo dos contatos sucessíveis entre ferramenta e o blank durante o forjamento.

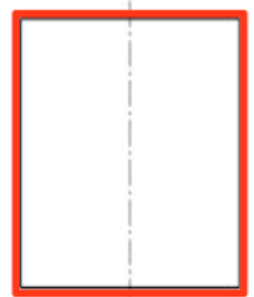

(a)

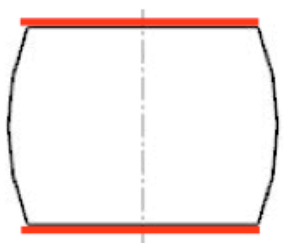

(b)

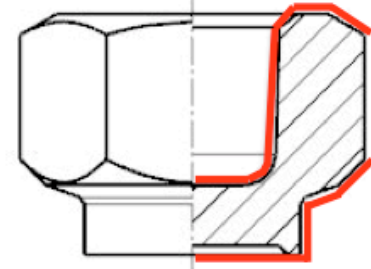

(c)

Figura 55 - Formação dos óxidos no blank durante o forjamento. 
No MEV, as seções transversais das operações de recalque e de forjamento da pré-forma foram observadas e avaliadas. As duas figuras seguintes foram feitas com base na análise da formação dos óxidos na superfície do blank, utilizando a Figura 55. A operação de recalque, apresentada na Figura 55 (b), é uma etapa de preparação do forjamento, porém suas ferramentas são simples e sem geometrias complexas. Esta operação é feita em matriz aberta e o contato com as ferramentas se dá apenas em duas regiões, a superior e a inferior. A geratriz do blank não entra em contato com nenhuma ferramenta.

A Figura 56, mostra o resultado obtido no MEV, utilizando o filtro de BEC, da interface de contato entre a ferramenta e o blank. Nesta região foi identificada a presença de uma camada fina e homogênea de óxido, indicada pela seta vermelha, em contraste com o núcleo do material, indicado pela seta azul, que é aço SAE 1045.
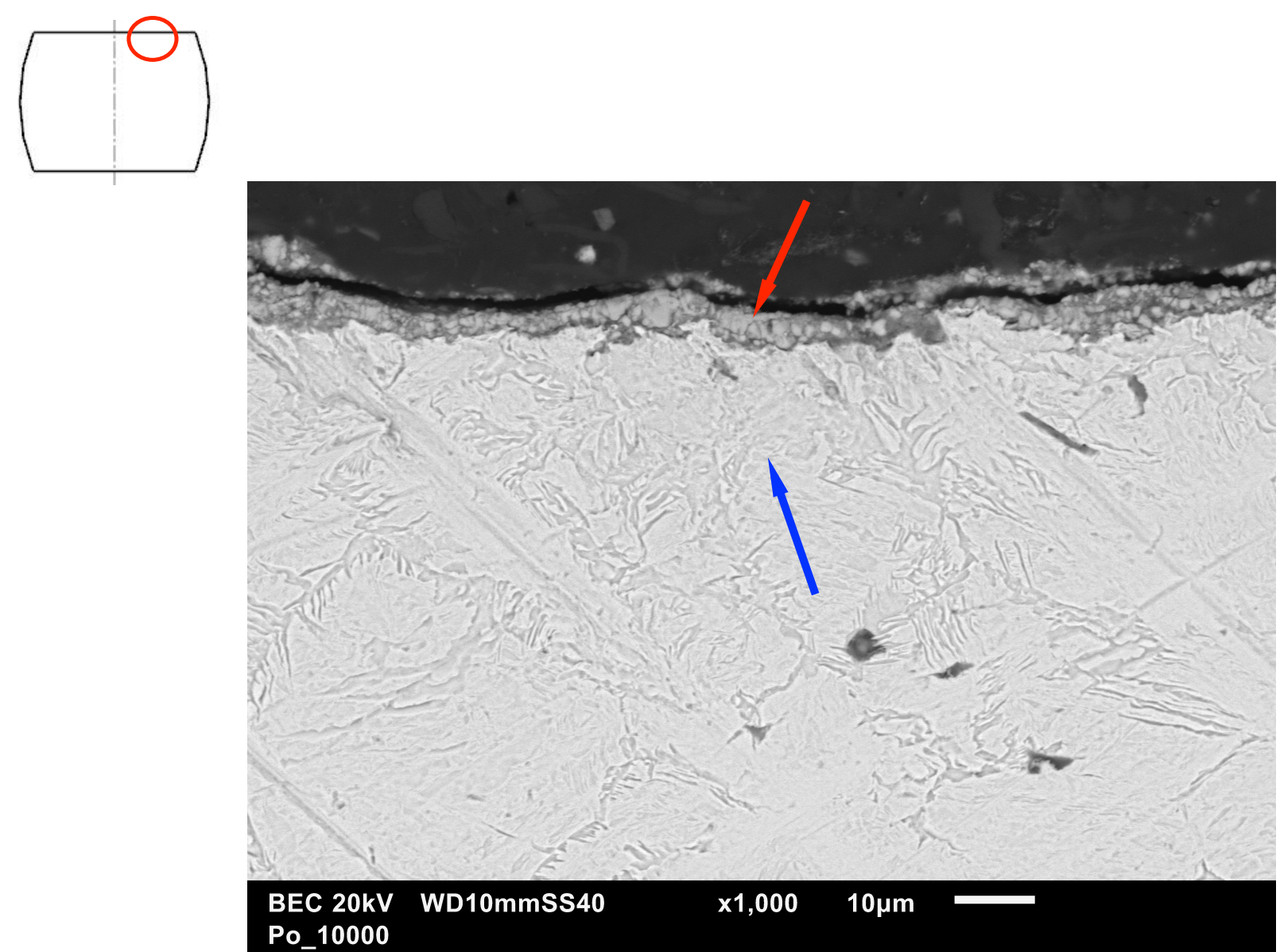

Figura 56 - Análise da seção transversal do blank recalcado - interface de contato com a ferramenta. 
Na Figura 57, o procedimento foi repetido e a região de análise foi a geratriz do blank recalcado, a qual não sofre contato com nenhuma ferramenta. Desta forma, a operação de recalque elimina a camada oxidada do material, a qual é proveniente do aquecimento. Embora também tenha sido verificada a presença de óxido, indicada pela seta vermelha, sua distribuição não é homogênea. Este aspecto pode estar diretamente ligado ao resultado da remoção da oxidação, durante a operação de recalque. O núcleo do blank, indicado pela seta azul, é semelhante ao apresentado na Figura 56.
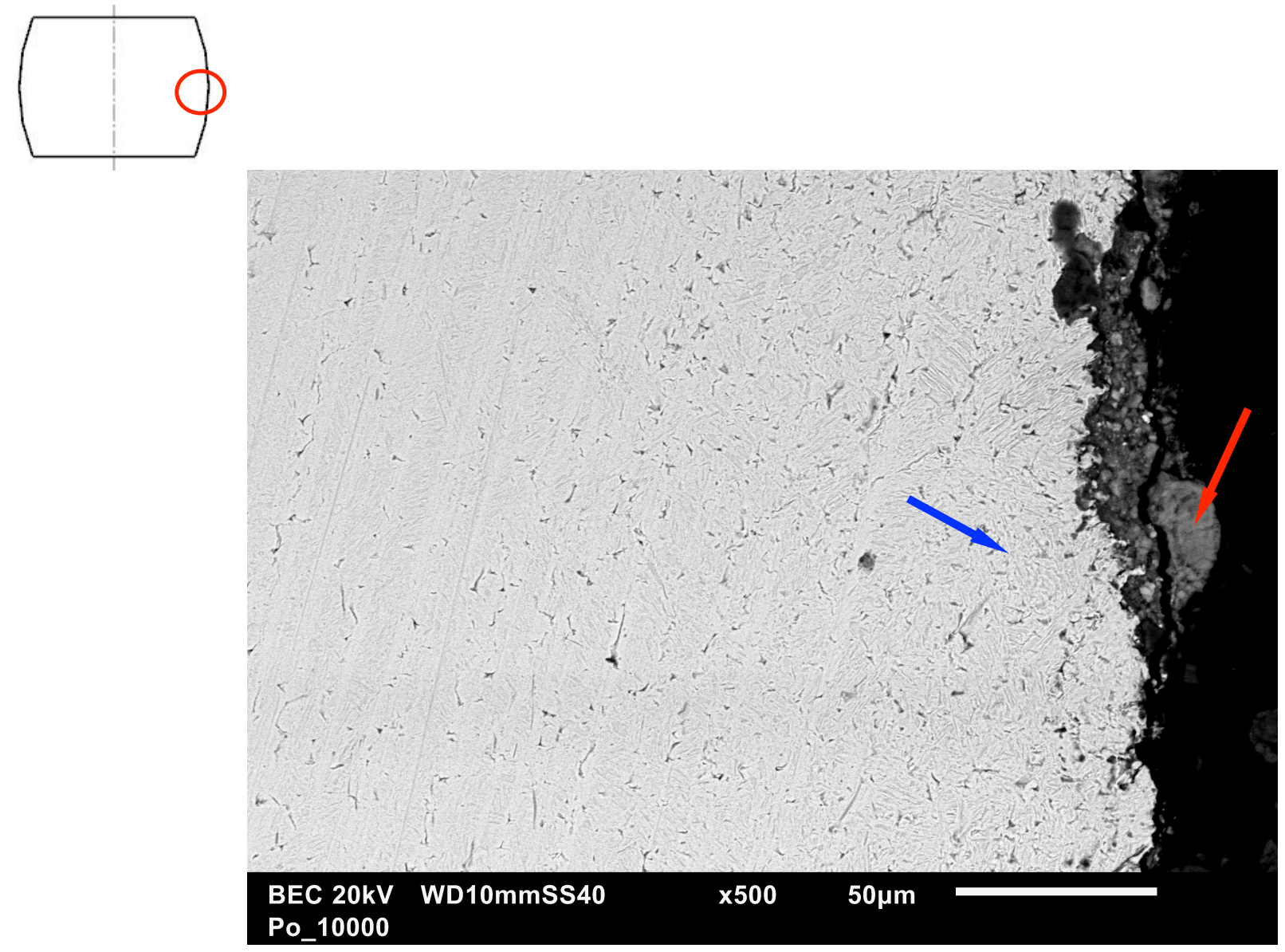

Figura 57 - Análise da seção transversal do blank recalcado - lateral

$\mathrm{Na}$ região do furo, região de contato do pré-furo, foi identificada a presença de óxido. Com espessura de cerca de $3 \mu \mathrm{m}$, a camada de óxido nesta região da porca está conforme a previsão feita na Figura 55 (c). Esta camada é o resultado do acúmulo de óxidos, deste o aquecimento da barra, até a operação de recalque. $\mathrm{Na}$ Figura 58, é possível observar a presença de óxidos na superfície interna do furo da porca, indicada pela seta vermelha, em contraste com o núcleo da porca que está indicada pela seta azul. 


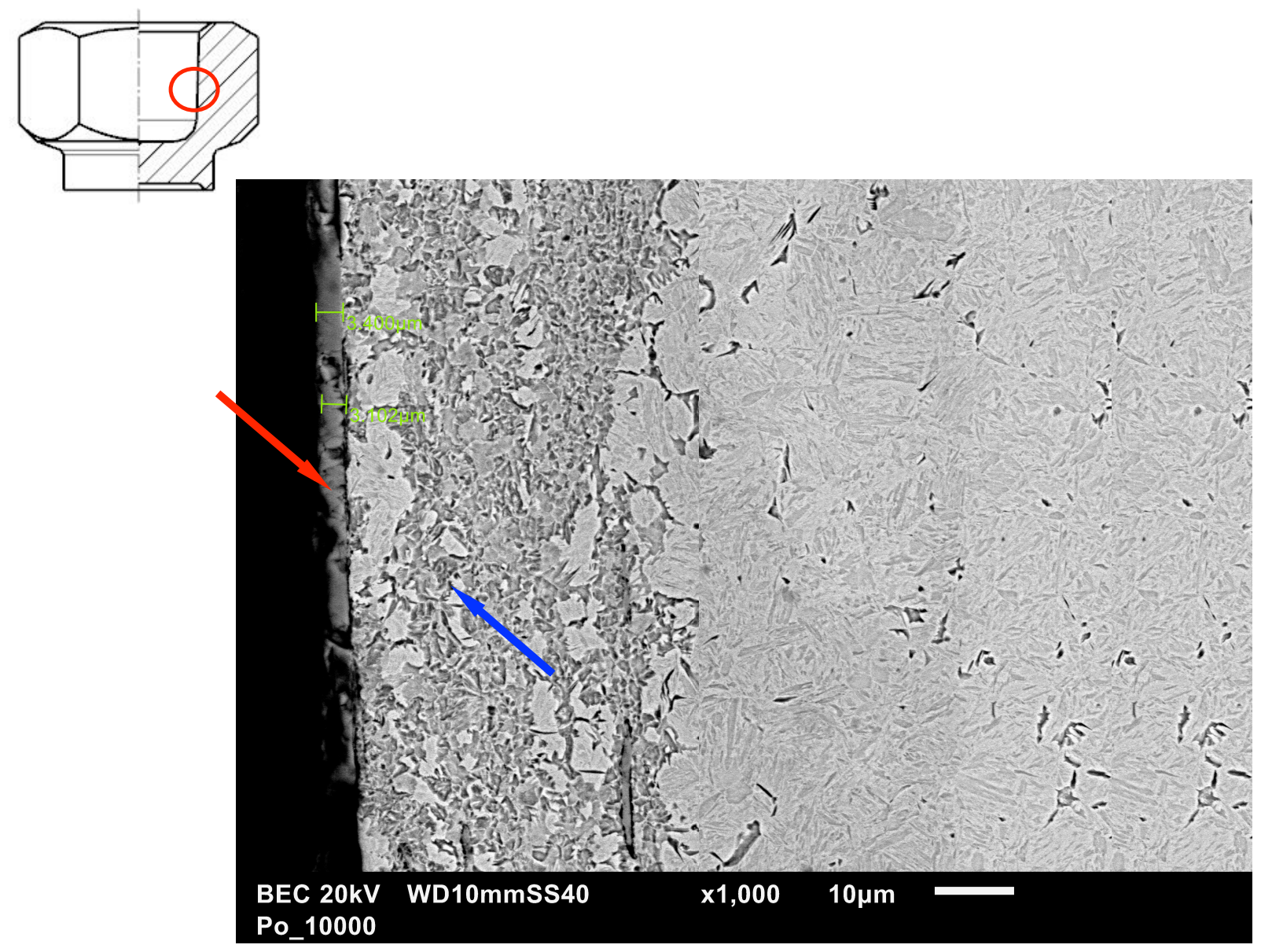

Figura 58 - Análise da seção transversal da porca - furo

No raio do furo da porca foi encontrada uma região da superfície interna do furo da porca em que a camada de óxido formada possivelmente foi arrancada ou transferida para o punção de pré-furo. Na Figura 59, a camada de óxido formada, indicada pela seta vermelha, foi encontrada com cerca de $6 \mu \mathrm{m}$ e distribuída homogeneamente sobre o material da porca, indicado pela seta azul. 


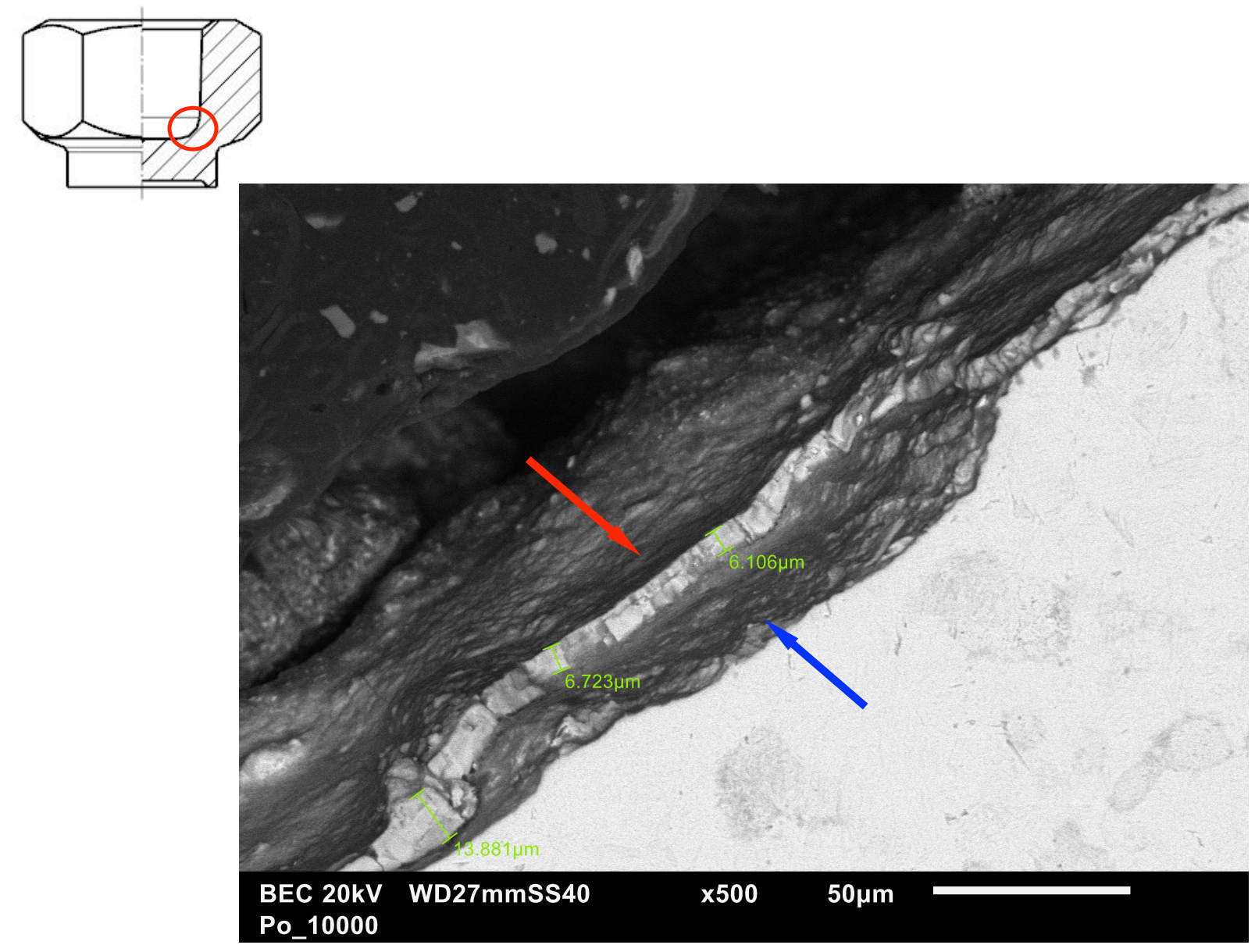

Figura 59 - Análise da seção transversal da porca forjada - Raio do furo

Outra constatação feita por meio da observação da seção transversal dos punções é a nucleação de trincas na superfície e propagação na camada existente sobre a superfície do punção. Uma vez que as trincas surgem na superfície da camada aderida, propagam-se pela camada até encontrarem a microestrutura e posteriormente propagam-se em direção ao núcleo da ferramenta.

A nucleação das trincas pode ser devido ao surgimento de tensões trativas na parte posterior do sulco formado uma vez que as trincas observadas na superfície dos punções estão dispostas perpendicularmente ao sentido de forjamento $[19,28]$. Outra hipótese provável para a nucleação das trincas é a fadiga térmica causada pelo gradiente térmico entre a superfície de contato e o núcleo da ferramenta (Figura 16) [41,42]. As trincas observadas na superfície dos punções apresentaram o mesmo aspecto de "leito de rio seco" encontrado na literatura (Figura 17) [42]. 
A presença de trincas na microestrutura causadas por fadiga térmica foi evidenciada por SJÖSTRÖM et BERGSTRÖM. Inclusive o resultado dos estudos conduzido por eles, aponta para presença de óxidos na ponta da trinca.

\subsection{Análise da Dureza}

A nanoindentação foi utilizada para verificar a dureza, à temperatura ambiente, da camada aderida na superfície dos punções P100, P500, P1000, P2000 e P10000. A análise da nanodureza auxiliou na comprovação da adesão de óxidos sobre a camada do punção e revelou a existência de dois óxidos diferentes, no mínimo, aderidos à superfície das ferramentas. Em cada punção foram feitas 5 impressões para se obter as durezas mínima e a máxima em cada punção. A Figura 60 mostra o mapa de impressões utilizadas na medição da nanodureza do punção P2000. Os pontos destacados, 0, 1, 2, 3 e 4, foram indentados sobre a camada aderida, indicada pela seta verde, próximos de uma trinca na camada aderida que propagou-se em direção ao centro da ferramenta, indicada pela seta vermelha.

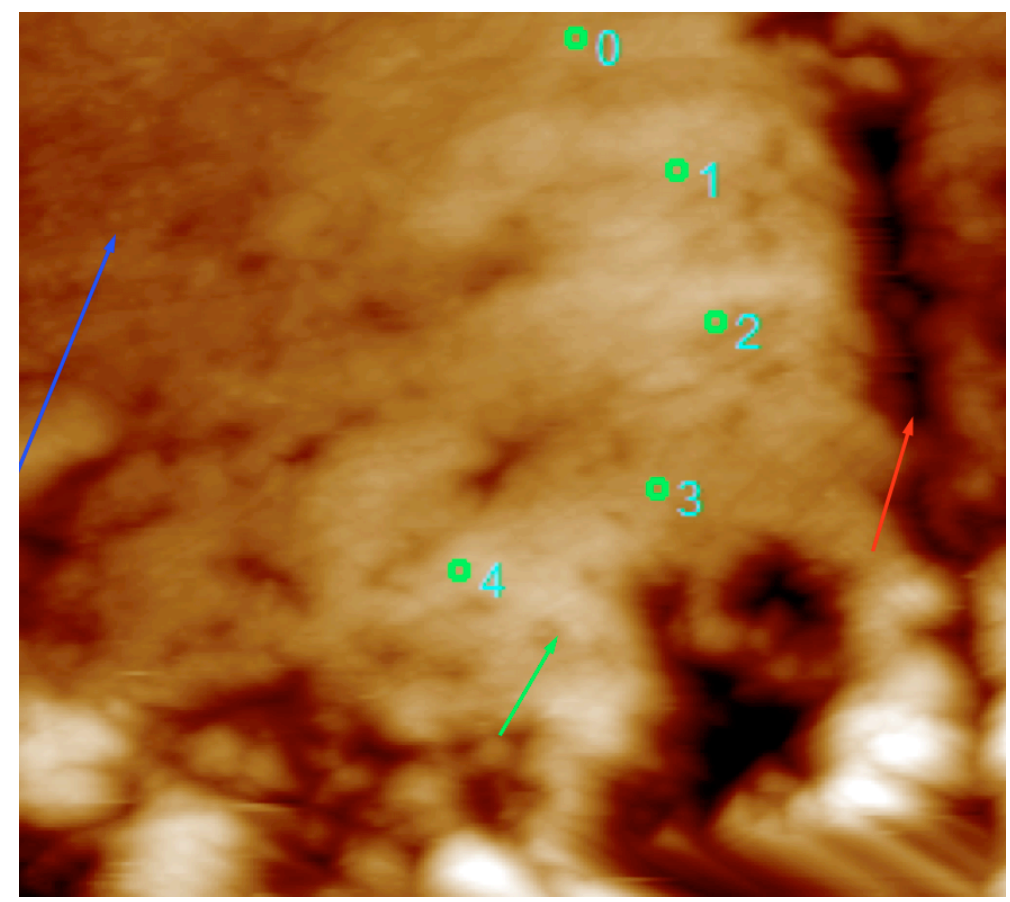

Figura 60 - Mapa de impressões realizadas na camada aderida do punção P2000

As impressões revelaram os valores mínimos e máximos encontrados nos punções P100, P500, P1000, P2000 e P10000. No gráfico apresentado na Figura 
61, a maior parte das impressões realizadas apontou para valores entre 4,1 GPa e 6,7 GPa, com exceção para os valores máximos obtidos no punções P500, P1000 e P10000. O valor mínimo encontrado foi de 4,1 GPa na camada aderida do punção P500 e o valor máximo encontrado foi no punção P10000, com valor de 13,5 GPa.

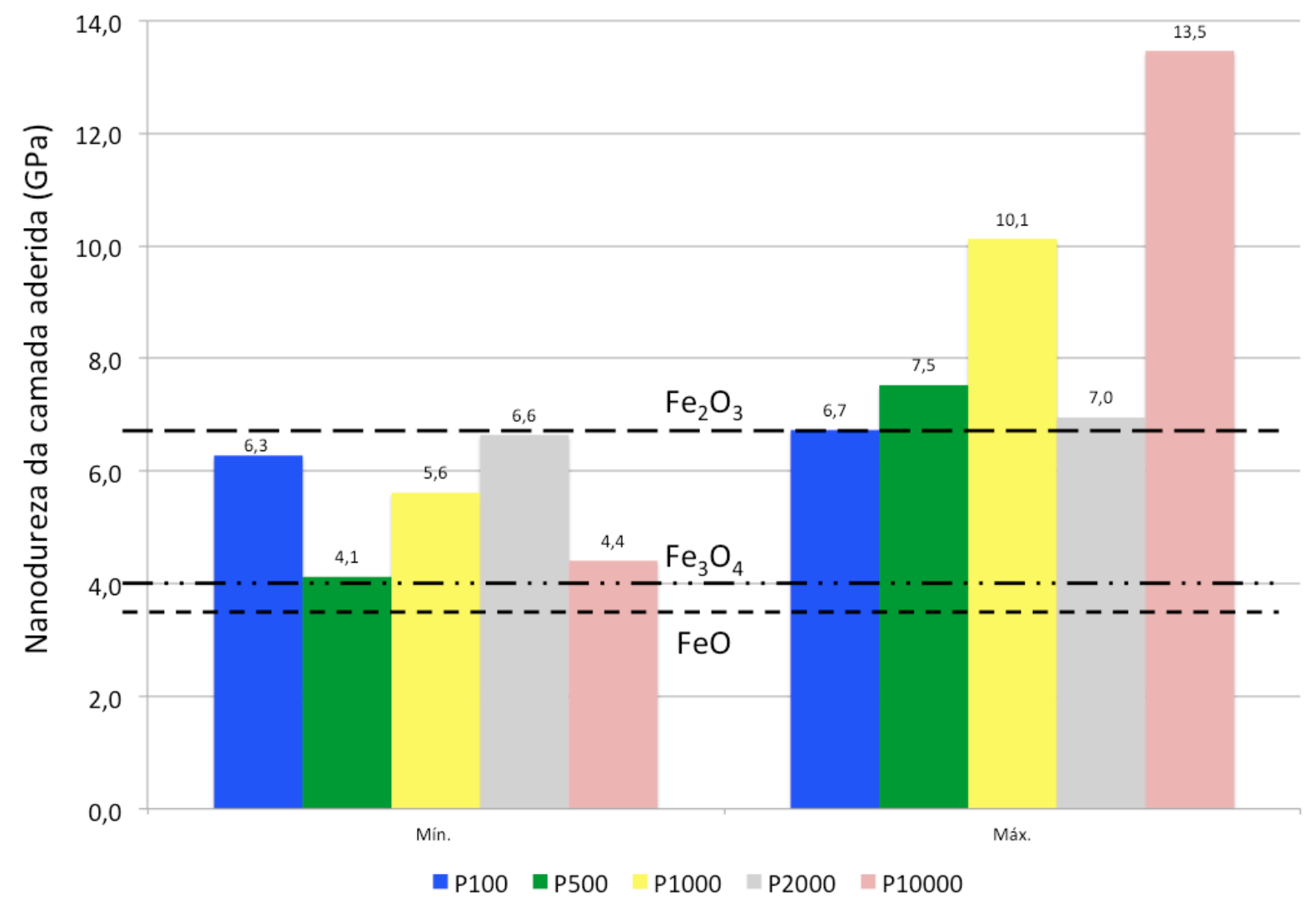

Figura 61 - Resultado da nanodureza da camada sobre a superfície dos punções.

Os resultados obtidos sugerem que as camadas aderidas podem possivelmente ser formadas por magnetita $\left(\mathrm{Fe}_{3} \mathrm{O}_{4}\right)$ ou hematita $\left(\mathrm{Fe}_{2} \mathrm{O}_{3}\right)$ porque o resultado dos valores encontrados são semelhantes aos valores obtidos por TAKEDA e ROSENKRANZ (Tabela 6) [51,52]. Nenhuma impressão apontou para valores de dureza próximos ao da dureza do óxido de ferro wustita $(\mathrm{FeO})$, o qual é $3,5 \mathrm{GPa}$.

Em todos os punções, os resultados das medições da nanodureza da camada aderida apontaram para valores equivalentes às durezas encontradas para óxidos de ferro, e, os quais possuem dureza entre 4,0 $\mathrm{GPa}$ e 6,7 $\mathrm{GPa}$, respectivamente. 


\section{CONCLUSÕES}

Embora diferentes modos de desgaste tenham sido observados sobre a superfície da ferramenta, a transferência de óxidos do material forjado para a ferramenta seguida da remoção, mostrou-se como o principal causador dos danos na superfície do punção utilizado no forjamento a quente em prensa mecânica automática com refrigeração forçada por água.

Os outros modos de desgaste observados foram a abrasão e a fadiga térmica. No entanto, a abrasão ocorreu sobre a camada óxido transferida para a superfície da ferramenta e não diretamente no aço ferramenta H-10. Sobre a camada transferida e aderida foram observados riscos e sulcos, caracterizando a abrasão, e trincas, que podem ter sido provocadas pelos gradientes térmicos cíclicos. Possivelmente, estes modos de desgaste possam ter ocorrido diretamente na superfície da ferramenta, porém antes que a transferência de óxidos do blank tenha se instalado sobre a superfície dos punções.

A camada máxima de óxidos transferida do material forjado para a superfície dos punções variou entre $10 \mu \mathrm{m}$ e $42 \mu \mathrm{m}$, onde foram encontradas durezas, obtidas por nanoindentação, entre 4,1 GPa e 13,5 GPa, levando a concluir que de fato a camada aderida é de óxido e como o EDS da seção transversal apontou concentrações baixas de elementos de liga na camada aderida, a suposição inicial que óxidos provenientes do blank se alojavam sobre a superfície do punção mostrou-se verdadeira.

Contudo, o desgaste no punção de pré-furação é acumulativo e irreversível. Inicia-se com cerca de $1 \%$ da vida útil do punção, e aumenta à medida que a quantidade de peças forjadas aumenta. 


\section{SUGESTÕES PARA TRABALHOS FUTUROS}

No decorrer do desenvolvimento deste trabalho, foram observados alguns assuntos que podem ser avaliados e estudados no futuro para melhorar o desempenho das ferramentas de forjamento a quente no ambiente fabril e consequentemente contribuir para a redução de custo de operação.

O estudo mais detalhado da adesão da camada de óxido proveniente do conta-corpo sobre as ferramentas pode colaborar com o entendimento do desgaste adesivo em ferramentas de forjamento a quente. Pode-se:

a)Quantificar o impacto da adesão de óxidos do contra-corpo na superfície das ferramentas e correlacionar com os outros modos de desgaste. Com isto, será possível estudar contramedidas para diminuir o desgaste em ferramentas de forjamento a quente;

b)Identificar e avaliar a camada máxima de óxido possível de ser aderida na ferramenta. Devido à dureza semelhante ou até superior, os óxidos aderidos à superfície das ferramentas podem atuar como retardadores do desgaste em ferramentas.

Adicionalmente, o entendimento da nucleação e propagação das trincas na camada aderida pode contribuir com a redução da incidência de trincas na microestrutura e, consequentemente, contribuir com o aumento da vida útil de ferramentas que falham devido à fadiga térmica. 


\section{REFERÊNCIAS}

[1] ANFAVEA - Anuário da Indústria Automobilística, Associação Nacional dos Fabricantes de Veículos Automotores, disponível em <http://www.anfavea.com.br/anuários.html>, acessado em 08 de fevereiro de 2017.

[2] EUROFORGE - Global Trends, disponível em www.euroforge.org, acessado em 05 de Junho de 2015.

[3] ALTAN, T., OH, S., GEGEL, H. - Conformação de Metais - Fundamentos e Aplicações. Escola de Engenharia da Universidade de São Paulo, $1^{a}$ Ed., São Carlos 1999.

[4] SOUZA, M. M.; PEREIRA, M. H.; SOUZA, T. S. G. - Fabricação e Caracterização de Componentes Forjados para Transmissões. In: $12^{\circ}$ Simpósio SAE Brasil de Powertrain, Sorocaba, São Paulo, 2014.

[5] ASM, ASM Handobook - Forming and Forging Vol. 14, 9. Ed., American Society for Metals ASM, 1993.

[6] LANGE, K. - Handbook of Metal Forming, 1. Ed., Society of Manufacturing Engineers - SME, 1985.

[7] MAGRI, M. L. - Influência da Topografia Superficial na Vida da Matriz de Forjamento a Quente, Dissertação de Mestrado, Faculdade de Engenharia Mecânica da Universidade Estadual de Campinas, Campinas, 2004.

[8] MESSMER, G.; HUBER, S. - Hot Forging on Horizontal Multi-Stage Presses, Seissenschimdt, 2007.

[9] SUMMERVILLE, E.; VENKATESAN, K.; SUBRAMANIAN, C. - Wear Processes in Hot Forging Press Tool, Materials \& Design, Vol. 16, Number 5, Austrália,1995, p.289-p.294.

[10] ABACHI, S. - Wear Analysis of Hot Forging Dies, Master's Dissertation, The Graduate School of Natural and Applied Sciences The Midle East Technical University, 2004.

[11] BÖRDER, C. - Análise do Coeficiente de Atrito do Anel para o Forjamento a Quente, Dissertação de Mestrado, Escola Politécnica da Universidade de São Paulo, São Paulo, 2005.

[12] SANTAELLA, M. L. - Fatores que Influenciam no Desgaste de Matrizes de Forjamento a Quente de Bielas Automotivas, Dissertação de Mestrado, Faculdade de Engenharia Mecânica da Universidade Estadual de Campinas, Campinas, 2009.

[13] HATEBUR - Portfólio de Produtos Forjados a Quente, disponível em www.hatebur.com, acessado em 05 de Junho de 2015.

[14] DIETER, G. E. - Mechanical Metallurgy SI Metric Edition, McGraw-Hill Book Company, Londres, 1988.

[15] DIN 8580, Manufacturing Processes - Terms and definitions, division. Deutsches Institut Fur Normung, 2003.

[16] DIN 8583, Manufacturing Processes - Forming Under Compressive Conditions - Part 5. Deutsches Institut Fur Normung, 2003.

[17] SERIACOPI, V. Simulação Numérica do Campo de Tensões na Microestrutura do Aço Ferramenta AISI H13 Durante o Forjamento a Quente. 2013. 150 p., Dissertação de Mestrado em Engenharia Mecânica, Universidade de São Paulo, São Paulo, 2013. 
[18] HIRSCHVOGEL, M.; DOMMELEM, H.V. Some applications of cold and warm forging. Journal of Materials Processing Technology, v.35, p. 343-356, 1992.

[19] SOUZA, T. S. G. - Efeito da Rugosidade no Desgaste de Punções de Conformação a Frio. 2016, 96 f., Dissertação de Mestrado em Engenharia Mecânica, Universidade de São Paulo, São Paulo, 2016.

[20] VILLARES METALS, Aços Ferramenta - Aços para Trabalho a Quente, disponível em www.villaresmetals.com.br , acessado em ,26 de Junho de 2015.

[21] BABU, S. A. - Material and Surface Engineering for Precision Forging Dies, 1999 Consortioun.

[22] SCHMOLZ BICKENBACK, Product Portofolio, disponível em www.schmolzbickenbach.com.br, acessado em 26 de Junho de 2015.

[23] BÖHLER, Hot Work Tool Steel, BÖHLER W320, disponível em www.bohler.com, acessado em 26 de Junho de 2015.

[24] RAHN, R.; SCHRUFF, I. - Improved Tool Performance and Cost Control in the Forging Industry - A Challenge for Innovative Tool Steels, 8th International Tooling Conference, Aachen, Alemanha, 2009, p.593-p.224.

[25] JOST, H. P. - Tribology - Origin and Future, Wear 136, 1989, p.1-p.18.

[26] SINATORA, A. - Tribologia: Um resgate Histórico e Estado da Arte, Erudição apresentada com parte dos requisitos do concurso para professor titular do departamento de Engenharia Mecânica, Escola Politécnica da Universidade de São Paulo, São Paulo, 2005.

[27] HUTCHINGS, I. M. - Tribology - Friction and Wear of Engineering Materials, 1992.

[28] STACHOWIAK, G. W.; BATCHELOR, A. W. - Engineering Tribology - Tribology Series Vol. 24, Austrália, Butterworth Heinemann, 1993.

[29] ZUM GAHR, K. H. Microstructure and wear of materials. New York: Elsevier, 1987.

[30] BABU, S. A. - Material Based Approach to Create a Wear Resistant Surface for Hot Forging, Tese de Doutorado, Ohio State University, Columbus, 2004.

[31] SCHEY, J.A. - Tribology in Metalworking: Friction lubrication and wear. American Society for Metals, 2ed., 1984.

[32] ASTM-G40-15. Standard Terminology Relating to Wear and Erosion. ASTM International. West Conshohocken, PA, www.astm.org, 2015.

[33] EYRE, T. "Wear characteristics of metals." Tribology International 9(5): p.203-p.212. 1976.

[34] BURWELL, J. T. "Survey of possible wear mechanisms." Wear 1(2): p.119-p141. 1957.

[35] GATES, J. D. "Two-body and three-body abrasion: A critical discussion." Wear 214(1): p.139p.146. 1998.

[36] PENAGOS, J. J. Efeito do Refinamento da Microestrutura e da Adição de Nióbio na Resistência ao Desgaste Abrasivo de Ferros Fundidos de Alto Cromo. 2016, 140 f., Tese de Doutorado em Engenharia Mecânica, Universidade de São Paulo, São Paulo, 2016.

[37] TREZONA, R.; ALLSOPP, D.; HUTCHINGS, I. "Transitions between two-body and three-body abrasive wear: influence of test conditions in the microscale abrasive wear test." Wear 225: 205-214. 1999. 
[38] ANDREIS, G.; FUCHS, K.-D.; SCHRUFF, I. - The Wear Behaviour of Hot-Work Tool Steels Used in Forging Processes, $8^{\text {th }}$ International Tooling Conference, 2006, p.593-p.600.

[39] MENDES, M. A. R. S. Estudo do Desgaste de Ferramentas Com e Sem Revestimentos de Filmes Finos Utilizados em Operações de Conformação a Frio. 200973 f., Dissertação de Mestrado em Engenharia Mecânica, Universidade de São Paulo, São Paulo, 2009.

[40] SINGH, A. K.; ROOKS, B. W.; TOBIAS, S. A. - Factors Affecting Die Wear, Wear 25, 1972, p.271-p.279.

[41] ENGLUND, D.; FORSSTRÖM, D. - Investigation Into the Failure of Hot Horming Tools and Their Tribological Behaviour, Master Dissertation, Luleå University of Technology, 2010.

[42] SJÖSTRÖM, J.; BERGSTRÖM, J. - Thermal Fatigue in Hot-Working Tools, Scandinavian Journal of Metallurgy, Vol. 34, 2005, p.221-p.231.

[43] UOL, Universo Online SA., disponível em http://noticias.bol.uol.com.br/fotos/imagens-dodia/2014/02/04/falta-de-chuvas-afeta-abastecimento-de-agua-em-sao-

paulo.htm?fotoNav=364\#fotoNav=367, acessado em 22 de Setembro de 2015, 2015.

[44] BERGSTRÖM, J; SJÖSTRÖM, J. - Thermal Fatigue Testing of Chromium Martensitic HotWork Tool Steel After Differente Austenitizing Treatments. Journal of Materials Processing Technology, 153-154, 2004, p.1089-p.1096.

[45] CALISKANOGLU, D.; SILLER, I.; EBNER, R, LEITNER, H.; JEGLITSCH, F., WALDHAUSER, W. - Thermal Fatigue and Softening of Hot Work Tool Steels, 6th International Tooling Conference, Karlstad, Suécia, 2002, p.707-p.719.

[46] PERSSON, A.; HOGMARK, S.; BERGSTRÖM, J. - Simulation and Evaluation of Thermal Fatigue Cracking of Hot Work Tools Steels, International Journal of Fatigue, Vol. 26, 2004, p.1095p.1107.

[47] CSER, L; LANGE, K.; GEIGER, M.; KALS, J. A. G. - Tool Life and Tool Quality in Bulk Metal Froming, Annals of the CIRP Vol. 41, 1992.

[48] WALTER, S.; HAFERKAMP, H.; NIEMEYER, M.; BACH, Fr.-W; HENZE, A. - Material Failure Mechanisms of Forging Dies, $5^{\text {th }}$ International Tooling Conference, 1999, p.215-p.223.

[49] BARRAU, C.; BOHER, C.; VERGNE, C.; REZAI-ARIA, F. - Investigations of Friction and Wear Mechanisms of Hot Forging Tool Steel, $6^{\text {th }}$ International Tooling Conference, 2002.

[50] BARRAU, C.; BOHER, R.; GRAS, F.; REZAI-ARIA, F. - Analysis of The Friction and Wear Behaviour of Hot Work Tool Steel Forging, Wear, Vol. 255, p. 1444-1454, 2003.

[51] TAKEDA, M., ONISHI, T., NAKAKUBO, S., FUJIMOTO, S. "Physical Properties of Iron-Oxide Scales on Si-Containing Steels at High Temperature" Materials Transaction. Vol. 50, No. 9: 22422246. 2009.

[52] ROSENKRANZ, A., REINERT, L., GACHOT, C., ABOUFADL, H., et al "Oxide Formation, Morphology and Nanohardness of Laser Patterned Steel Surfaces" Advanced Engineering Materials. No.8-17: 1234-1242. 2015.

[53] KOHOPOÄÄ, J.; HAKONEN, H.; KIVIVUOURI, S. - Wear, 1989, Vol. 130, p.103-p.112.

[54] BEHRENS, B.-A.; BOUGUECHA, A.; KAMMLER, M.; KLASSEN, A. - Investigations on Die Roughness of Hot Forming Tools, $8^{\text {th }}$ International Tooling Conference, 2006, p.437-p.438.

[55] KANNAPPAN, A. - Wear in Forging Dies - A Review of World Experience, Met. Form., Vol 36 (No. 12), Dec 1969, p 335; Vol 37, Jan 1970, p 6. 
[56] BERGSTRÖM, J.; RÉZAï-ARIA, F. - High Temperature Fatigue of Tool Steels, 7th International Tooling Conference, 2004, p.545-p.554.

[57] FARHANI, M; AMADEH, A.; KASHANI, H.; SAEED-AKBARI, A. - The Study of Wear Resistance of Hot Forgng Die, Hardfaced by a Cobalt-Base Superalloy, Materials Forum , Vol. 30, 2006, p.212-p.218.

[58] ARCELOR MITTAL. Guia do Aço, disponível em <http://brasil.arcelormittal.com.br/pdf/quemsomos/guia-aco.pdf>, acessado em 15 de abril de 2016, 2016.

[59] ABNT NBR NM ISO 6507-1. Materiais metálicos - Ensaio de dureza Vickers. Parte 1: Método de ensaio. Rio de Janeiro, 2008. 22 p.

[60] OLIVER, W. C., PHARR, G. M. - An Improved technique for Determinig Hardness and Elastic Modulus Using Load and Displacement Sensing Indentation Experiments. Journal of Materials, Vol. 7, Nr 6, 1992. 